\title{
ALCALÁ ZAMORA: UN REPUBLICANO DEMÓCRATA Y UN CRISTIANO
}

\author{
POR \\ CRISTÓBAL ROBLES MUÑOZ \\ Instituto de Historia, CCHS, CSIC, Madrid
}

RESUMEN: Este trabajo quiere presentar a un cristiano, que amó la libertad, creyó en ella y trabajó para que llegara a todos por la vía de la justicia y del respeto a la ley, que resuelve dificultades y conflictos, reconociendo al otro igual dignidad y respeto y dando igual comprensión y tolerancia. Alcalá Zamora vivió una libertad fraterna, cómplice, compañera del otro. En su casa aprendió a unir Dios y libertad. Su familia venía de aquellos liberales que miraban a los otros y los hallaban "benévolos y benéficos".

Vale más la libertad que las tradiciones y los intereses que se oponen a ella. Quiso que los cristianos fueran ciudadanos sin privilegios. Quiso que la Iglesia se sintiera protegida por la ley, bajo el signo de la libertad.

"Homo homini res sacra". Esa sacralidad de la compasión inspiró una ética privada y pública basada en la sencillez del trato y en la austeridad. Ese fue el rastro que dejó Alcalá Zamora. No se cansó de dar palabras a su razón. Lo hizo incluso cuando otros no honraron la suya, como se vio en el debate del que luego fue el artículo 26 de la Constitución. Su respuesta fue dimitir.

PALABRAS CLAVES: Alcalá Zamora, II República, libertad, ley, cristiano, demócrata, liberal

\section{ALCALÁ ZAMORA: A DEMOCRAT REPUBLICAN AND A CHRISTIAN}

\begin{abstract}
This paper wants to present a Christian, who loved liberty, believed in it and worked to reach all through justice and respect for the law. This solves problems and conflicts, because it recognizes the other equal dignity and respect and given equal understanding and tolerance. Alcalá Zamora lived a free fraternal accomplice, partner of another. At home he learned to unite God and freedom. His family came from those liberals who looked at the others and were "benevolent and beneficent."

The freedom worths more than the traditions and interests that oppose it. He wanted Christians to be nonprivileged citizens. He wanted the Church to feel protected by law, in the sign of freedom.

"Homo homini res sacra". This sacredness of compassion inspired private and public ethics based on the simplicity of treatment and austerity. That was the trail left Alcala Zamora. He never tired of explaining the reasons for their rights. He did it even when others did not honor their word, as seen in the discussion of which was then Article 26 of the Constitution. His response was to resign.
\end{abstract}

KEY WORDS: Alcalá Zamora, Second Republic, freedom, law, Christian, Democrat, liberal.

Recibido/Received 2011-09-15

Aceptado/Accepted 2011-12-06

Frente a la disciplina que mantiene el orden, Alcalá Zamora afirmo que este se asienta en ese principio de que nadie es más que otro, alargado hasta esa exhortación que invita a estimar a los otros por encima de uno. "Homo homini res sacra". Esa sacralidad de la compasión inspiró una ética privada y pública basada en la sencillez del trato y en la austeridad. Ese fue el rastro que dejó Alcalá Zamora. 
Hay un aspecto que extraña en su biografía. ¿Era un viejo regalista como lo fue el partido liberal? ¿Fue un anticlerical, tal como se entendió entonces? Respondió a ello en público, exponiendo su posición en el debate constitucional y su intervención como Presidente de la República en la tramitación de la Ley de Confesiones y Congregaciones Religiosas. Memorias y archivos hablan de su esfuerzo por conseguir que la libertad no fuera agresiva, que las leyes se negociaran, que las Cortes no fueran una "convención" donde una mayoría mecánica declarara siempre "vencida" a la minoría.

La libertad, aun sin buscarlo, choca con quienes tienen privilegios que juzgan legítimos e intangibles. No dudó Alcalá Zamora en aceptar un modelo de relaciones del Estado con la Iglesia, que estaban ya vigentes en la República Francesa y en la República de Portugal. Quiso que no se repitieran errores, cuyo recorrido político fue corto. Unos y otros creyeron que estaba equivocado. En este trabajo interesa sobre todo destacar que, como cristiano y liberal, no se retiró cuando había que estar, hablar y actuar.

Una Iglesia complicada con tantos intereses y tantos derechos ligados a la defensa de ellos, necesitaba descargarse de esos aspectos que, mostrando su gloria, ocultaban su obediencia, su seguimiento y su escucha de quien "padeció, fue crucificado, muerto descendió hasta el fondo de la exclusión y de la maldición". Glorificado, está junto a quien hace justicia a la viuda, al huérfano, a la mujer sin hijos, al pobre, al extranjero, y se complace en quienes viven bajo esa humillación que acompaña la desprotección y la aflicción. ${ }^{1}$

Quizás una clave del menguado éxito de quienes esos años unieron Dios y libertad como guía de sus vidas sea que, en la Iglesia, hay gente que la presenta y quiere como un poder. Lo hacen de modo que los que están fuera de su recinto, extramuros, la vean extraña y hasta enemiga. En su misión de reconciliar, en la paz y en la justicia, el Estado podría, al menos, reivindicar intervenciones que mantuvieran la igualdad sin privilegios. El Estado ha de tener pautadas esas iniciativas y estas deben realizarse negociando, hablando, para mostrar que no viene con violencia, sino con razón.

\footnotetext{
*Este trabajo forma parte del Proyecto HAR 2008-01002/HIST, "España y la Santa Sede en la Europa de Entreguerras. Una perspectiva Comparada (1930-1939)".

FUENTES CITADAS:

ASV Arch.Deleg.Messico Busta 73 fasc. 381 76-77

ASV Arch.Nunz.Madrid 910 (1) 4-5 y 3

Arxiu Vidal i Barraquer. 1971 Esglesia $i$ Estat durant la segona republica espanyola 1931-1936, I 14 d'abril- 9 d'octubre 1931, $1^{a}$ y $2^{a}$ Partículo Índexs, Textos en Llengua original. Edició a cura de M. Batllori i V. M. Arbeloa, Monestir.

Arxiu Vidal i Barraquer 1986 Església i Estat durant la Segona República Espanyola 1931-1936. Textos en la llengua original, Edició a cura de M. Batllori i V.M. Arbeloa, IV 10 d'octubre de 1933 -18 juliol 1936, $3^{\text {a }}$ Part, Monestir de Montserrat.

DS/CC Diario de las Sesiones de las Cortes Constituyentes (1931-1936)

1 "Cuando la Iglesia, con la pompa de la corte renacentista, creyó eliminar el ocultamiento y convertirse en "puerta del cielo" y "casa de Dios", se convirtió una vez más y casi más que antes, en eclipse de Dios, que difícilmente podría encontrarse en ella. Lo más pequeño cósmicamente es el auténtico signo de Dios en el que se revela como el totalmente otro que nuestras expectaciones no pueden reconocer. La nada cósmica es el todo verdadero, porque el "para" es lo propiamente divino...", Ratzinger, J. 1995. Introducción al cristianismo, Barcelona, Planeta-Agostini. Recoge un ciclo de conferencias en la Universidad de Tubinga en el curso 19671968.
} 
Alcalá Zamora no se cansó de dar palabras a su razón. Lo hizo incluso cuando otros no hicieron honor a la palabra dada, como sucedió del que luego fue el artículo 26 de la Constitución. Su respuesta fue dimitir.

\section{FE A PRUEBA DE DESENGAÑOS}

En su intervención a favor del proyecto de reforma de la Ley Municipal, el 9 de febrero de 1906, extrañó a Alcalá Zamora la oposición de los conservadores. Presentado por el Gobierno presidido por Moret, era "una protesta ardiente, una fe ciega en el concepto de la libertad, arma clásica que cura por sí misma los males que causa.

Es la mejor expresión de una fe que está a prueba de desengaños y a salvo de pesimismos y considera que la libertad, en su acción, si ocasiona males, son pocos junto a los bienes que produce. Borrando el recuerdo de los primeros deja, en definitiva, "la acción saludable de los segundos". 2

Libertad y nación española van unidas en una tradición que halló expresión en las Cortes Constituyentes de Cádiz. En los juegos Florales celebrados en Valencia el 4 de agosto de 1910, habló Alcalá Zamora de regionalismo, calificando la negación de la patria como apostasía y suicidio.

"La incompatibilidad de los sentimientos regionales con los nacionales, y la aspiración insensata de restaurar la soberanía de las regiones, es flaqueza y desvarío de algunos alucinados por la historia, que llevó a su ojos la ceguera, y a su espíritu, la demencia, haciéndoles olvidar que los períodos históricos, ni pueden detenerse, ni pueden reconstituirse".

No se detienen, pues cada uno, al acabarse, da paso al siguiente. No puede imitarse, porque es la más valiosa de las "antigüedades", pero no puede restaurarse en lo que fue.

Su estilo de vida tenía eje y fundamento en la tolerancia, pues ella

"debe ser anhelo vivísimo que responda a la intensidad de sentimiento en el creyente, inspirándole, cuando, no por amor al prójimo, por consideraciones de egoísmo, el terror a la intolerancia, con solo pensar que azares de la fortuna, exigencias de la vida o designios de la Providencia, le hubiesen llevado a vivir a donde no predominara su fe religiosa e imperase la imposición política de la mayoría en materia de conciencia...Es precisa la libertad política para que, en todo instante, la expresión de cada creyente fuera la ofrenda espontánea de su conciencia y no la imposición indigna de coacciones ajenas".

Libertad y nación como espacio donde vivirla y sentirla, como proyecto y mirada hacia delante, sabiendo que repetir el pasado es un error. Cada tiempo tiene sus urgencias, sus posibilidades abiertas, sus asuntos que resolver, sus cuentas pendientes, que deben saldarse con trabajos y esperanzas. Hay que estar con el otro y con-vivir, porque la tolerancia alerta frente al deseo de eliminar al prójimo y a la

2 Alcalá Zamora. N. 1979. "Proyecto de Ley de Reforma de la Ley Municipal", 9 febrero 1906, Discursos, Madrid, Editorial Tecnos, 57. Insistió en estos conceptos en el debate de la "Reforma del Régimen de la Administración Local", el 28 de enero de 1907, Ibídem 65-66

Hispania Sacra, LXIV, Extra I, enero-junio 2012, 69-148, e-ISSN: 1988-4265, doi: 10.3989/hs.2012.027 
indignidad de doblegarse ante poderes tiránicos. Una religión interior no necesita negociar con sus creencias ni con las palabras que la sostienen en la conciencia. ${ }^{3}$

El 28 de junio de 1912 intervino en el debate sobre las Mancomunidad Provinciales. Defendió el sentido de la unidad nacional de España. Era un asunto de cultura nacional. El Estado tiene una "altísima función pedagógica. En lo temporal, es "el órgano supremo e insustituible" en la dirección de la enseñanza. Porque necesita cantidad y calidad de cultura. Esta se asienta en cuatro pilares: la soberanía nacional, la unidad frente al cosmopolitismo destructivo y destructor, la cohesión interna frente a los particularismos disolventes y el deber cívico y el respeto a la ley frente a todas las cegueras de la rebeldía".

Señaló entonces la buena intención del proyecto: traer la paz de los espíritus. Pero lo se hacía a título de préstamo, en forma de hipoteca. La prenda eran quietud y falta de libertad en el futuro. Calmará pasiones, pero abrirá conflictos. Sus beneficios serán efímeros. Los problemas aparecerán pronto.

Como diputado, siente que le faltan voluntad, derecho y fuerza para decir: "la historia de España está equivocada y hay que rectificar su rumbo, hay que rehacer la obra que, por el amor y la previsión, trazaron la más grande de las Reinas de Castilla y el más hábil de los Monarcas de Aragón". 4

El 7 de diciembre de 1922 entró Alcalá Zamora en el Gobierno presidido por García Prieto. Ocupa la cartera de Guerra. Volvió a plantearse la reforma del artículo 11 de la Constitución. Una vez más, los obispos protestaron. ¿Qué significado tenía la presencia de Alcalá Zamora en este ministerio liberal y democrático? Aquella propuesta de reforma constitucional pretendía que el Estado fuera laico, pero nada tenía que ver con un proyecto laicista sobre la sociedad. ${ }^{5}$

Quería Alcalá Zamora que apareciera una generación de españoles creyente y abnegada, que trabajara en esa obra, aun sabiendo que no la verá consumada. Una generación valiente no se echará atrás ante todas las exigencias del heroísmo frente a la adversidad, y perseverará en el sacrificio oscuro. Una generación feliz, que asegura su propia paz y goza y sueña con días venturosos. Una generación enraizada en la historia, que la analiza y ahonda en sus orígenes con la gratitud noble y vidente de los profetas.

Sabía que la realidad da sorpresas que aceleran el paso y acortan los tiempos y la espera. Por eso instaba a seguir trabajando con fe, con la satisfacción del deber cumplido, con generosidad hacia quienes vienen detrás y alargan los límites de la existencia. Cada uno debe concretar su deber en el estímulo al esfuerzo y trabajar esperando y soñar viviendo. ${ }^{6}$

3 Alcalá Zamora, N. 1979 "Fuegos florales de "Lo Rat Penat”, Valencia 4 agosto 1910, 408-410 405406.

4 Alcalá Zamora, N. 1979. "Mancomunidades Provinciales” 28 junio 1912, 86-87 y 82.

${ }^{5}$ Fue el rasgo que diferenció a Alcalá Zamora y Azaña en el debate sobre la Constitución de la República en octubre de 1931. La posición prohibición de que las congregaciones enseñaran separaba a quien era liberal y quien creía que la función directiva del Estado ponía trabas a la libertad de enseñanza. Alcalá Galve, A. 2006 Alcalá Zamora y la agonía de la República, Sevilla, Fundación José Manuel Lara, segunda edición, 95 y 140 .

${ }^{6}$ Alcalá Zamora, N. “Juegos Florales en el Ateneo de Sevilla”, 12 marzo 1914, 433. 
Presentaron el 13 de noviembre de 1918 en el Congreso los diputados republicanos una proposición de ley para otorgar la "autonomía integral" a Cataluña. La división que creó el tema forzó la caída del Gobierno de García Prieto. Romanones le sucedió el 5 de diciembre, y se encontró con una situación política muy crispada.

En este ambiente de nacionalismo inconciliable, Alcalá Zamora consideraba que la Gran Guerra había consagrado el éxito de los modernos estados-nación liberales frente a los viejos y caducos imperios multinacionales. Solo entre éstos, perdedores de la contienda mundial, se había desarrollado la fórmula disolvente y empobrecedora de Woodrow Wilson a favor de la segregación de las nacionalidades sin Estado. Eso buscaba Cambó para Estado nacional ya existente, como era España. Alcalá-Zamora rebatió sus argumentos.

Sostuvo que el proyecto de "autonomía integral" respondía más a un propósito separatista que federalista. Decía "toda solución federal es un proceso de aproximación" y "todo proceso de autonomía es, por el contrario, de apartamiento, y, aun cuando sea leve la desviación inicial, alarma el sentido que ella lleva". Entrando en el contenido de las Bases, reprochó que éstas no cerraran el tema de los límites territoriales de Cataluña, pues parecía alentar un propósito imperialista hacia las regiones vecinas. ${ }^{7}$

¿Puede una nación sobrevivir con desigualdades fiscales? No. Así lo dijo en el debate el 18 de diciembre de 1918 y lo repitió el 7 de febrero de 1919.

Pero no era solo la cuestión catalana. El asunto afectaba a toda España, puesto que los catalanistas fomentaban en toda la nación un espíritu regionalista que, en lugar de responder a "una lenta evolución diferencial" de regiones específicas, estaba llegando a "comarcas donde la diferenciación no tiene siquiera asiento".

El Estado autonómico era la negación de las conquistas igualitarias del liberalismo e introducía, por la acción disolvente del catalanismo, insolidaridad con sus mezquinos egoísmos económicos:

“En España ¿sabéis lo que la gente de abajo entiende por autonomía? De todo lo grande, de todo lo noble, de todo lo venerando que hay en las tradiciones vascas, la gente no saca nada: lo único que ve es pagar.

“Autonomía, en España, se llama desigualdad tributaria; autonomía, para la gente del pueblo, y por eso os sigue en muchas partes, significa una gigantesca, colectiva e impune defraudación. Eso es lo que ve mucha gente, creyendo que la autonomía al practicarse no significará una administración más complicada, sino una verdadera Jauja. Y hay una ilusión irreflexiva, porque el pueblo español no se da cuenta, no se puede dar cuenta, cuando pretende imitaros, cuando pretende copiar una realidad viva, de cuáles serían las consecuencias hoy día en España de un fraccionamiento en nacionalidades ficticias, aun cuando entre ellas quedaran débiles vínculos"

Alcalá-Zamora era presidente de la Comisión de Autonomías. Rebatió casi todos los artículos del proyecto presentado por la Mancomunidad.

${ }^{7}$ Gil Pecharromán, J. 2005. Niceto Alcalá-Zamora, un liberal en la encrucijada. Madrid. Ed. Síntesis, 108-109. Sobre esta "vocación" imperial", Ucelay Da Cal, E. 2003. El imperialismo catalán. Prat de la Riba, Cambó, D’Ors y la conquista moral de España, Barcelona, Edhasa. 
"El Estatuto catalán, a título de una pretendida voluntad de Cataluña, cercena las atribuciones Estado, modela la vida del Estado, regula las relaciones de Cataluña con el resto del país, y esto no se puede hacer. A título de voluntad de Cataluña, aun suponiendo que fuera unánime, no se puede determinar la estructura del Presupuesto nacional, no se puede regular la emisión futura de Deuda, no se puede asaltar el Tesoro de la Nación arrancándole las contribuciones directas; no se puede organizar la Justicia ante la cual han de litigar los demás ciudadanos españoles, no se pueden reducir a condiciones de súbditos sin derecho a los demás españoles que residen en Cataluña si no se someten al derecho civil catalán (...) Hay, pues, Sr. Cambó, una ilegitimidad flagrante, un exceso de poder manifiesto, que aun en lo constituyente, no hablo de lo constituido, condena la obra que supone el Estatuto catalán." 8

En este marco, cabía un ejército de la nación. Está para su defensa. Dos defectos capitales impiden que España tenga uno apto para la defensa externa. El primero, la falta de "todo ideal internacional, que, constante o súbito, es el que organiza los Ejércitos". Esta carencia no puede suplirse con la sumisión de satélites". El segundo defecto, ligado al primero, ha hecho que sea "el resumen de nuestras guerras civiles". En ellas, actuó como sostén, amenaza, apoyo, "de un régimen, de una solución, de una política".

Importaba a los gobiernos satisfacer al personal, pero sin atender la dotación de material. "Nunca el ejército para defensa externa, siempre para el mantenimiento de un orden, por podrido que fuera, en la vida interna".

No era un análisis de gabinete, sino el examen, ponderado y sin paliativos, de lo que estaba pasando en Marruecos. Faltaba jun Ejército colonial. Era ineficaz la organización militar en su conjunto, y además estaba "ese mismo problema, que, como rescoldo aviva de cuando en cuando, de las Juntas, aspiración de las recompensas, el tema de los ascensos".

Estaba cambiando el, signo de la intervención del ejército en la política. Lo recordará en 1945. Se pasaba del pronunciamiento al militarismo. El primero se produce al servicio de una política, no en interés de los militares. El militarismo surge más tarde, en un contexto de agitación social. Los militares se contagian de los métodos sindicales. Por eso es un movimiento más grave que el pronunciamiento, "porque compromete, mina y pronto rompe la compenetración nacional de la fuerza armada con el país".?

Alcalá-Zamora consideraba las Juntas de Defensa un serio peligro para el ejército y para el régimen civil de la Monarquía, "porque yo tengo una ecuación político-militar, y en ella digo: un Ejército dividido es igual de dos Ejércitos indisciplinados, situados el uno frente al Gobierno, en actitud de protección, seguramente bochornosa, cara e indigna (...). Y es que, frente a las Juntas, el Poder público tiene que dar la sensación de no percibirlas, de no someterse a su influjo, de una austera y estricta justicia, que haga innecesaria la presión de ellas, de una fortaleza tan digna que haga ineficaz cualquier extralimitación que se interponga atajar el camino de Poder público". ${ }^{10}$

${ }^{8}$ Gil Pecharromán, 2005 111-113.

9 Alcalá Zamora. N. 2000. "Régimen político de convivencia en España, 1945, Obra Completa, Coordinación de la edición José L. Casas Sánchez, y Francisco Durán Alcalá, Priego de Córdoba, 179-180. Apareció en Buenos Aires, Editorial Claridad, 1945. En esta edición 67-233. Confiesa que fue escrito entre febrero y marzo de 1937, p. 71.

${ }^{10}$ Alcalá Zamora, N. 1979 “Política de España en Marruecos”, 8 y 9 noviembre 1921, 171-172. 
Practicó Alcalá Zamora la "religión del deber", expresión laica de los mejores liberales del siglo XIX. Quiso cumplirlo en cada circunstancia para poder encarar el juicio de quienes no entendieran sus decisiones. Cada cosa a su tiempo. Y siempre dispuesto a dar razones. Deber y sentido de la realidad marcaban su ritmo vital. ${ }^{11}$

\section{UNA POLÍTICA DE ABNEGACIÓN, NO DE AMBICIONES}

Alcalá Zamora advirtió en 1923 a Alfonso XIII, "el dinasta dictador", que no fuese hacia la dictadura. Dijo después al general Primo de Rivera que se apresurara a cerrar esa etapa. ${ }^{12}$ Animó a las clases conservadoras para que ayudasen a salvar lo que hubiera de justo y viable en sus intereses. Avisó a los republicanos que

"la Constitución irreflexiva y demagógica, sin ponencia ni criterio de gobierno, con amenaza estéril para la propiedad, hostilidad pasada de moda hacia la Iglesia, Cámara única y parlamentarismo desenfrenado, sería el desastre que sólo retardó y contuvo mi esfuerzo desde la jefatura del Estado. Supliqué una reforma transaccional de aquel conjunto de dislates, que hoy parecería ideal a los vencidos y quizás a los vencedores, sin pensaran que se hubiese evitado todo; y no me oyeron". ${ }^{13}$

En su "Declaración a favor de la República", dijo en Valencia el 13 de abril de 1930: España estaba en la fase avanzada de un período constituyente. La Dictadura había deshecho la legalidad hasta el punto de que era imposible restablecer la Constitución. Nada quedaba de la Constitución salvo la facultad de censurar lo que se dice y escribe. Y la nación tenía que recuperar su soberanía.

En pocos días desaparecieron Dictadura y Dictador. ¿Por qué no se normalizó la vida nacional? Porque ni una ni otro eran el obstáculo. Urgía ir a unas elecciones libres y abrir un proceso constituyente.

Son los culpables de un delito de lesa democracia española, en primer lugar, los que se llaman a sí mismos "constitucionales". Un despotismo, una dictadura, no los necesita. Estaban ahí para asegurar una retirada, pues la aventura salió mal. Eran meros defensores de "los intereses creados", manteniendo la antigua farsa, ${ }^{14}$ vestidos ahora "palafreneros distinguidos".

11 “A quien tenga impaciencia por juzgar conducta, que examine mi vida y repare que ni yo abandono el deber ni lo olvido nunca. Por creer que cumplía con mi deber, he dimitido, y cuando se conozca los hechos y cuando el debate pueda tener amplitud, que cada cual juzgue, yo adelanto la esperanza de que se me pueda formular el reproche de que dimití tarde y que resistí bastante tiempo".Alcalá Zamora, N. 1979 "Crisis ministerial del 26 de mayo de 1923”, 250-252

12 "Todo el problema del régimen, toda la intranquilidad de España, el desdoro de sus instituciones, el perjurio inconstitucional, la arbitrariedad absoluta, la marcha sin salida posible hacia el destronamiento y el caos, fue la obra directa de la corona que, realizando el afán vesánico de poder pleno, integral, omnímodo, fue ciega, pero derecha, a la abdicación sin remedio...". La única alternativa estaba entre una catástrofe sangrienta o un desenlace pacífico. Este fue posible gracias a la "intuición nacional" y la buena voluntad de algunos hombres, que se arriesgaron a intentarlo.

${ }^{13}$ Alcalá Zamora N. 2000. "Régimen político de convivencia en España”, 1845 79-70. La cita anterior, 87.

${ }^{14}$ Era una clara alusión a la obra de Jacinto Benavente estrenada en 1907. Hay una edición, con introducción, de Francisco José Díaz de Castro y Almudena del Olmo Iturriarte, Madrid, 1998.

Hispania Sacra, LXIV, Extra I, enero-junio 2012, 69-148, e-ISSN: 1988-4265, doi: 10.3989/hs.2012.027 
De los que sirvieron a la Dictadura ni siquiera debe hablarse. Y lo peor es que ahora pretenden cubrir responsabilidades ajenas, "asumiéndolas como propias". Eso no puede ser, porque ellos no fueron "ministros constitucionales". Eso no es gallardía, sino un "pacto de impunidad" para salvar a la Corona. La Dictadura ha hecho recusables todos los poderes, sin exceptuar el del Congreso y del Senado.

Frente a las Constituciones de papel, de las que habló Romanones, están las Constituciones que recogen la voluntad de los pueblos y que tienen grabadas fidelidad o escarmiento. Este, jurídicamente, significa inhabilitación "que desposee; extrañamiento que coloca la violación más allá de nuestras fronteras".

Sí puede hacerse algo frente a quienes tienen la fuerza. Los ejércitos han usado el asedio. Los civiles pueden recurrir al "bloqueo".

No puede ensayarse lo que fracasó en 1870: recurrir a una dinastía extranjera para conservar la Corona. Era "moralmente imposible la continuación" de Alfonso XIII o de un heredero suyo. Entre el deseo de libertad de los españoles y el "atávico impulso" de la dinastía, apenas ha habido tregua, si se exceptúa la época de Cánovas.

La solución es la República. Esta a nadie debe excluir, ni siquiera a los ex ministros, que además tienen el deber de servirla. En las relaciones Gobierno-Corona hay un tercero: el pueblo, sujeto de la soberanía. Eso sintió Alcalá Zamora cuando juró como ministro ante la patria, la Constitución y el Rey.

Avisó a los otros republicanos, a los de abolengo y a los recién llegados, que "una República que se entregue en sus comienzos solo a los republicanos está destinada a morir inevitablemente".

Alcalá Zamora proclamó el derecho y el deber de los monárquicos demócratas y constitucionales de servir, votar, propagar la República "como una solución ideal mejor para España". El factor decisivo que empujaba hacia el cambio de régimen era "la reacción ante la torpeza del Rey y la mordaza de la Dictadura". Los demócratas, constitucionales estaban obligados a anunciar que la República sería cada día más avanzada, más radical, porque en esa dirección marchaba el mundo.

Quería Alcalá Zamora que su significación política fuera el centro, ni la derecha ni la izquierda, para eso era preciso que hubiera gentes dentro de ella más a la derecha que él. En ese momento pronunció, al hablar de la presencia de la Iglesia en el Senado, la célebre frase, que duró en la memoria de quienes conocieron los sucesos del 12-14 de abril de 1931:

"Y vais a decirme algunos: ¿con el arzobispo de Valencia? Sí y con el cardenal de Toledo, que es más en todos los aspectos de jerarquía y de reacción".

Debía ser una "República viable, gubernamental, conservadora". En ella situaba una solución transaccional.

"Pues como yo quiero representar una política de conciencia, una política de abnegación y no una política de ambiciones, si España, en una solución transaccional, que yo veo tan difícil, cree 
encontrar la paz que la gobiernen otros, que yo no siento ambiciones y me basta con la tranquilidad de mi casa".

En Valencia, procedía recordar a Vicente Ferrer y su papel en el compromiso de Caspe. En el siglo XX, en recorrido inverso, se trata de "por las vías legales, por el camino del derecho, dejar vacante un trono ocupado".

Quería una "República viable, gubernamental, conservadora, con el desplazamiento consiguiente hacia ella de las fueras gubernamentales de la mesocracia y de la intelectualidad española". Se declaraba dispuesto a servirla y gobernarla, a propagarla y defenderla. No sería un Kerensky de una República "convulsiva, epiléptica, llena de entusiasmo y de idealidad", pero "falta de razón".

Pocas semanas más tarde, el 21 de mayo, en el Ateneo de Madrid, hablaba de una República conservadora como la mejor solución a la crisis revolucionaria que padecía la monarquía. Para encauzarla, se necesitaba a "los hombres llamados de orden", que, recogiendo la victoria de la revolución, la hagan fructífera y viable, con su visión clara, serenidad, y mano dura si es necesario, para sofocar cualquier desmán". ${ }^{15}$

A la monarquía española le faltaban ya todas las condiciones para ser viable. Su caída en casi todos los países parecía un vendaval. Lo explicó Alcalá Zamora. La primera condición es que la monarquía no hiera el sentimiento nacional. La segunda, tacto exquisito en el uso del poder personal a la hora de intervenir. "Saber contener, como exigencia de los tiempos, el afán inmoderado de gloria, el empeño de aparecer realizando fantásticos sueños de engrandecimiento nacional". La tercera condición es que se mantenga fiel a los rasgos que le dieron su perfil histórico. La española ha de ser liberal, esencialmente, intensamente, y, por tanto, debe respetar la Constitución y el Parlamento.

Las monarquías "no tienen la potestad de luchar por su existencia". Por eso pidió a la española que se mantuviera limpia de toda mancha de sangre. No fue así tras los fusilamientos de los pronunciados en Jaca en diciembre de 1930.

Las monarquías caen por sí solas. No se las derriba. Las gentes de orden no debían acudir a sostenerla. Era inútil. ${ }^{16}$

En la Sociedad Económica de Amigos del País, de Málaga, el 20 de mayo de 1930 dijo que los ricos necesitan aprender a ser conservadores. Quienes en esos días eran tachados de revolucionarios y perturbadores, eran "los guardianes del orden público".

En nombre del pueblo, de la solidaridad suprema de los intereses de la Nación, pedía a los ricos que cumplieran sus "inmensos deberes". Debían percibir la conveniencia de un cambio de régimen que aportara certeza y seguridad en la vida económica, cerrando el grave momento constituyente y atendiendo las aspiraciones del pueblo.

15 Alcalá Zamora, N. 1979. "Declaración a favor de la República", 13 abril 1930, 475-496. Gil Pecharromán, J. 2005. 178 y 185.

16 Alcalá Zamora, N. 1979, “Condiciones de viabilidad para las monarquías”, Bilbao 30 abril 1930, 497-511.

Hispania Sacra, LXIV, Extra I, enero-junio 2012, 69-148, e-ISSN: 1988-4265, doi: 10.3989/hs.2012.027 
El orden debe fundarse en la libertad. En ella puede desenvolverse la riqueza. Las clases ricas tuvieron su papel con Cánovas. La Constitución de 1876 les dio sitio en el Senado. Por eso no podía explicarse que hubieran apoyado la Dictadura.

No cabe neutralidad en una situación de guerra civil. Deben colocarse donde mejor crean defendidos sus bienes y derechos. Nadie se engañe, la revolución es inevitable. Los ricos únicamente pueden hacer que no sea contra ellos. ${ }^{17}$

Sobre la cuestión de Cataluña, va a intervenir en el verano de 1930, cuando se creó el Comité Revolucionario. En agosto de 1930 fue Alcalá-Zamora a San Sebastián dispuesto a escuchar las exigencias particularistas de los republicanos catalanes, pero también a evitar que se convirtieran en una amenaza para el conjunto de la nación.

A las tres y media de la tarde del 17 de agosto, los convocados se reunieron en el Casino Republicano de San Sebastián. Presidía Fernando Sasiaín, dirigente local de la Unión Republicana, y se encontraban presentes, por Alianza Republicana, Lerroux y Azaña; por el radical-socialismo, Marcelina Domingo, Álvaro Albornoz y Galarza; Alcalá-Zamora y Maura por la Derecha Liberal; Casares Quiroga, por los republicanos gallegos; Jaime Aiguader, de Estat Català; Macià Mallol, de Acció Republicana y Manuel Carrasco Formiguera, de Acció Catalana. A título de independientes figuraban Felipe Sánchez Román, Eduardo Ortega y Gasset y el socialista Indalecio Prieto.

Aiguader representaba de forma más nítida la posición separatista, pero el peso del debate lo llevó Carrasco Formiguera. Recalcó la necesidad de que la futura República reconociera la personalidad diferenciada de Cataluña y que esta se manifestara en un régimen político particular. Carrasco exigió el derecho a la autodeterminación y llegó a plantear la posibilidad de la independencia.

Albornoz manifestó con aspereza su desacuerdo y Maura afirmó que aquel camino conducía al separatismo y a la guerra civil y que el Estatuto catalán no podía ser obra "de cuatro señores alrededor de una mesa". Prieto manifestó su preocupación de que los muy reaccionarios nacionalistas vascos utilizaran ese resquicio para plantear sus reivindicaciones de autogobierno.

Para sorpresa de todos, dada su larga historia de pleito con el catalanismo, Lerroux se mostró especialmente conciliador, dispuesto, según escribió más tarde, a enseñar a sus correligionarios "cómo se lidiaban aquellas fieras".

Terció entonces Alcalá-Zamora con argumentos jurídicos que allanaron el camino del consenso. ${ }^{18}$ Partidario de la aspiración de Cataluña a la autonomía, creía que las regiones españolas no debían agregarse como entes soberanos en un Estado federal, mediante pactos voluntarios, sino que debían ser las Cortes, supremas depositarias de la autoridad y soberanía de los españoles, las que decidiesen la forma de Estado.

Preguntó a los catalanes si aceptaban como base de cualquier acción política la Declaración de Derechos del Hombre, y, al responder éstos que sí, señaló que el sufragio universal, dando la palabra a

17 Alcalá Zamora, N. 1979. "Deberes y preocupaciones de la riqueza” en Sociedad Económica de Amigos del País, Málaga, 20 de mayo 1930, y Bilbao 30 abril 1930, 512-522. La designación del momento como "guerra civil", 520.

${ }^{18} \mathrm{Su}$ intervención en Alcalá Zamora, N. 1977. 134-138 
todos los ciudadanos, decidiera el régimen que la República daría a Cataluña. Por lo tanto las Cortes tendrían la última palabra sobre el Estatuto autonómico

Liberal consecuente, oponía así el concepto individual de los derechos políticos de los ciudadanos de un Estado a la concepción organicista y antidemocrática de la nación como entidad decisoria y sujeto global de derechos, tan en boga entre los nacionalismo europeos.

Quedó, finalmente, encauzado un principio de acuerdo, basado el reconocimiento de "la personalidad de Cataluña". Los partidos catalanes elaborarían un Estatuto de autonomía regional, sometido luego al estudio y aprobación de las Cortes Constituyentes. ${ }^{\mathbf{1 9}}$

"La República quiere aún implantarse en paz. Resuelto, si no lo consigue, a implantarse en guerra. Pero hay una necesidad de que cada uno, para cumplir su deber y para llenarse de razón, escuche cuál es el puesto que le corresponde: A nosotros, no intentar la algarada inútil, sino el esfuerzo arrollador y decisivo. $\mathrm{Y}$ a ellos, cuando España en pie pronuncie su voluntad en marcha, seguirla como escolta, precederla como vanguardia, abrirse en filas como en una procesión cívica; inclinar la bandera en señal de respeto, como en una parada. $\mathrm{O}$ a nuestro lado, o apartándose: enfrente, nadie, porque nadie tiene derecho a cerrar el paso a la voluntad decidida de España".

En su intervención en el mitin del 28 de septiembre de 1930. Habló en nombre de la Derecha Liberal Republicana. Apeló a la conducta ciudadana, a abandonar el temor, a respetar la ley y el orden. Y dijo que nada podría ofrecer la Segunda República a Alfonso XIII. Dirigió al ejército dirigió una aviso:

"La República quiere aún implantarse en paz. Resuelto, si no lo consigue, a implantarse en guerra. Pero hay una necesidad de que cada uno, para cumplir su deber y para llenarse de razón, escuche cuál es el puesto que le corresponde: A nosotros, no intentar la algarada inútil, sino el esfuerzo arrollador y decisivo. Y a ellos, cuando España en pie pronuncie su voluntad en marcha, seguirla como escolta, precederla como vanguardia, abrirse en filas como en una procesión cívica; inclinar la bandera en señal de respeto, como en una parada. $\mathrm{O}$ a nuestro lado, o apartándose: enfrente, nadie, porque nadie tiene derecho a cerrar el paso a la voluntad decidida de España". ${ }^{20}$

\section{LA REVOLUCIÓN PACÍFICA Y FECUNDA}

Desde la memoria sentida por la tragedia de la Guerra Civil, Alcalá Zamora reflexionó sobre el significado del 12 y 13 de abril de 1931.

Si las otras dos Españas se empeñaban en preparar la Guerra Civil, la tercera tenía la misión de impedirla y librar así a los españoles de "su debilidad moral". Cuando en 1931 fue derribada la reacción, la tercera España tomó la delantera. Eso explica que los días 12-14 de abril fueran las fechas de una revolución pacífica y fecunda.

El 10 de mayo de este año fue una provocación imprudente de la derecha extrema, aprovechada, "no sin una minuciosa preparación", por la extrema izquierda, que empujó hacia los incendios y el

\footnotetext{
${ }^{19}$ Gil Pecharromán. J. 2005. 189-190.

20 "Mitin de solidaridad republicana", Madrid 28 septiembre 1930. Alcalá Zamora, N. 1979., 523-531.
} 
desorden. Ante esos acontecimientos, las derechas se inhibían y las izquierdas no fueron leales con los partidos republicanos moderados.

"Provocaron la elección de una Cámara constituyente, donde la tercera España era aplastada; y ocurrió lo mismo en las Cortes ordinarias, como resultado de un método electoral absurdo e injusto".

"La guerra civil desencadenada significó la derrota por adelantado de la tercera España". Sufrió odios en "las espantosas operaciones de retaguardia". Tuvo que someterse a los jefes de cada zona, sin poder elegir. Sus dirigentes vivían pobremente en el exilio. Para que la tercera España realice esa esperanza de renacimiento se necesita un cambio en la conciencia de los españoles, "que juzgue locura las soluciones extremistas". ${ }^{21}$

La coalición integrada en el Comité Revolucionario, presidido por él, no podía durar. Siendo tan heterogénea, consiguió un amplio respaldo social, una "mayor amplitud de ambiente y de sufragios, la mayoría nacional que le dio el triunfo. No se contenía esta, a su izquierda, en el Partido Socialista; no se detenía a su derecha en las gentes que, con disciplina o adhesión consciente, nos siguieron a Maura o a mi: se extendía gigantesca, muchísimo más, penetrando para derribarla, en la misma cimentación social y política de la monarquía”.

La República fue posible gracias a unas elecciones municipales de limpias. ${ }^{22}$

"La República no necesitó la violencia porque era segura la victoria, ni el odio, porque en verdad nació sin enemigos. Después, más o menos pronto, por el olvido de cómo surgió y de lo que debía y le convenía ser, llegó a tenerlos".

Para Alcalá Zamora, era indiscutible que vino por la decisión de la mayoría de los españoles. Era "voluntad nacional, libre y decisiva, , es decir, soberanía efectiva; solidaridad patria y republicana por encima de los partidos, o sea, una legalidad común a estos, y un acervo de intereses nacionales; ausencia de odios y de excesos, que afirma la convivencia humana confiada a la garantía de la justicia; rumbo hacia adelante, pero regido por una decisión consciente, que fija el ritmo y no aplasta vencidos, violencia excluida y guerras civiles terminadas y fuerza obediente, Ese sí es el espíritu del 14 de abril". 23

Al concluir su retrospectiva de la vida republicana en los cinco años de su presidencia, manifiesta su convicción de que es necesario rectificar para poder estabilizar el régimen. Eso implicaba "continuidad de propósito, patrimonio moral común de los partidos, predominio de sentido nacional, deseo de paz, espíritu de concordia, ambiente y práctica de convivencia; una vez más, y en una fecha que lo dice todo, volver a aquel 14 de abril, del que nos hemos desviado funestamente..., 24

Aquel día Alcalá Zamora se dirigió a todos los españoles en nombre del Gobierno Provisional. Destacó el civismo con que se proclamó la República: España estaba en paz. Tenía un Gobierno con un

21 “Confesiones de un demócrata”, “La tercera España”, L'Ére Nouvelle, 12 mayo 1937. Alcalá Zamora, N. 2000., 36-41.

${ }^{22}$ Alcalá Zamora, N. 2000. 8 y 20.

23 "Inventario objetivo de cinco años de República (1)" y (3), La Nación 23 junio y 9 de julio 1936, "Artículos publicados en el diario "La Nación" (Buenos Aires, 1936-1939), Alcalá Zamora, N. 2003. "Inventario objetivo de cinco años de República (2)", La Nación 28 junio 1936, 12-16

24 Inventario objetivo de cinco años de República ())", La Nación 3 septiembre 1936, Alcalá Zamora, N. 2003. "61-62 
programa de justicia social y de reformas administrativas, de supresión de injusticias, de depuración de responsabilidades y restablecimiento de la ley.

Pedía al pueblo una asistencia confiada y vigilante. La autoridad se funda en el apoyo de los españoles. Nadie debería dar motivos a quienes pudieran reaccionar contra la República. Si eso se produjera, la cordura de los republicanos, la sofocaría de inmediato.

"La normalidad en el país es completa y nos hemos posesionado sin el menor incidente y el primer acto del Gobierno ha sido la concesión de una amplia y generosa amnistía".

El Gobierno cumplirá su deber, restablecerá la ley y buscará el bien de la Patria”. ${ }^{25}$

"Estemos todos seguros de que España goza de una completa Aurora de amor entre las regiones...Con el corazón en alto, el Gobierno de la República no puede daros la felicidad, porque esto no está en sus manos, pero sí el cumplimiento del deber, la restablecimiento de la Ley y la conducta inspirada en el bien de la Patria". ${ }^{26}$

Desde el decreto de reinstauración de la República, Alcalá Zamora emerge como el jurista que da forma al régimen. Fue el defensor de la legalidad y encarnación ella. El país venía de una secular experiencia de "atajar" la ley, como denunció Antonio Maura. Y estaba estimulado, porque eso hacían los políticos. Para Alcalá Zamora, en España los ciudadanos tienen "escasa noción de la Ley". Es verdad que sí la tenía muy alta de la equidad y por eso no aceptaba la impunidad frente a los delitos de los poderosos. ${ }^{27}$

\section{PROFANACIÓN ANTIRREPUBLICANA E IRRELIGIOSA}

La primera gran fiesta después del 14 de abril fue el 1 de mayo. Ese día al patriotismo de las jornadas de abril se sumaba ahora "la esperanza de la paz social". Pocas jornadas más tarde, el 11 de mayo, se produjeron "los primeros excesos". Parecían estar aguardando algunos la primera provocación monárquica para mostrar una criminal demagogia, "saliendo de sus bajos, turbios y oscuros fondos" y "con turbias complicidades". Aquellos hechos no bastaron para hundir la República, pero mostraron sus grietas, al atacar las bases de la concordia nacional. Fueron una "primera profanación irreligiosa y antirrepublicana". ${ }^{28}$

En la etapa preparatoria de la República la masonería era una institución débil. Ayudó, pero poco, porque bastaba la inmensa mayoría de los españoles. "Creció, en cambio, mucho y rápidamente la masonería tan pronto en cuanto se instauró el régimen y, por su tendencia a protegerse e influir, supo asegurarse con disimulo tal número de Actas en las Constituyentes", que podían frenar o impulsar iniciativas parlamentarias en la medida en que favorecían o perjudicaban a un "Hermano".

Muchas de las maniobras, en forma de crisis y hasta de "golpe de Estado", fueron preparadas en las logias. Cita Alcalá Zamora la visita nocturna de Azaña a Alejandro Lerroux tras su ruptura en 1933, y la formación del Gobierno de Diego Martínez Barrio en octubre de ese año.

\footnotetext{
25 Texto en Alcalá Galve, A. 2006. 215-216

26 "Proclamación de la República", Madrid 14 abril 1931Alcalá Zamora, N. 1979., 533.

${ }^{27}$ Alcalá Galve, A. 2006. 67-68.

28 Alcalá Zamora, N. 1976 160-169.
} 
En otro orden, la masonería fomentó indisciplina y discordia en el ejército y en los servicios de comunicaciones.

"En suma, la masonería ayudó poco, perturbó bastante y dañó mucho a la República". Su control sobre los individuos, no los ha mejorado y ha creado conflictos internos en quienes querían ser leales, pero se lo impidió su obediencia masónica. ${ }^{29}$

El 11 de mayo de 1931 Alcalá Zamora se dirigió por radio a los españoles. El Gobierno se solidarizó con los creyentes que deploraban lo sucedido el día anterior. El Gobierno provisional había proclamado "la plena libertad espiritual".

Había antecedentes de esos sucesos bajo otras formas de Gobierno. El Provisional no había podido esa jornada mantener el orden y salvar la propiedad, toda sagrada, pero, en este caso, las que fueron atacadas afectaban a las creencias de muchas personas.

Cumplirá la Ley y empleará los recursos en sus manos para mantener el orden. La "torpe provocación monárquica" era uno de los flancos enemigos que tenía el Gobierno. Fue para este un honor que la República viniera sin tumulto ni agresión al derecho de nadie. Se volvió a ordenar el ingreso del general Dámaso Berenguer en prisiones militares. Se unificó la justicia. Quiso dejar claro que se pediría responsabilidades, pero no se establecería tribunales de excepción.

No estaba dispuesto a sacrificar a la popularidad su conciencia. Estaban equivocados quienes, "a título de conquista democrática o de salvaguardia de la República, pedían el desarme de la Guardia Civil". Esta no fue instrumento de la Dictadura. No estuvo a su lado el 13 de septiembre de 1923 y sí estuvo al lado del Gobierno provisional el 14 de abril. Fue constitucional y ha sido desde el primer momento republicana. Digan lo que digan contra él los agitadores, estaba obligado a prevenir al pueblo de que la Guardia Civil, leal al Gobierno, defenderá y salvará a la República de cualquier peligro que la aceche.

"La tranquilidad está restablecida. El Gobierno amparará el orden, Jornadas de desprestigio de la República no se consienten, la gloria con que nació hemos de procurar que se conserve". 30

Iniciada la guerra civil, Alcalá Zamora analizó los sucesos de mayo de 1931. La fiesta del Primero de Mayo se celebró en paz. Los sucesos del 10 de mayo fueron obra de mozalbetes, aún chiquillos, y de tipos criminales inconfundibles, que aparecen y huyen y ejecutan sus delitos con rapidez. Bastaba con el uso de la fuerza pública. Eso quiso Miguel Maura. Su conducta fue impecable. Había consenso en todos los partidos representados en el Gobierno. Aquel espectáculo "envilecido y envilecedor", debía acabarse.

Habló Alcalá Zamora del "veto práctico", sin mencionar a Azaña, pero se deduce, porque incluye en el consenso general a socialistas y a radical-socialistas.

Los sucesos de aquellas fechas tuvieron "enorme y dañosa trascendencia" en el rumbo de la República. Fue un grave obstáculo en su camino. Todos lo reconocen. Abrió la puerta a otras crisis,

\footnotetext{
29 Alcalá Zamora, N. Ibídem 201-202.

30 “Incendio de templos”, Madrid 11 mayo 1931, Alcalá Zamora, N. 1979. 532-537.
} 
que sucederían a esta primera y fue la más grave crisis del Gobierno Provisional. "Destruyó bastante, quebrantó más y pudo hundirlo todo".

Si el 14 de abril significa justicia y democracia, horizonte a avances políticos, sociales y religiosos, el 11 de mayo significa "violencia, odio sectarismo, crimen". Fue un momento que propició un desquiciamiento de la República y la puso en la vía hacia ese precipicio que "lleva a las dictaduras".

"Sin esa fecha, sin cuanto significa. Repulsivo y lamentable, no se pondrían comprender en su nuevo y desviado sentido, los hechos, las frustraciones, las contrariedades, de la revolución española". 31

\section{UNA CONSTITUCIÓN DESNIVELADA}

Quiso Alcalá Zamora que, ante la Constitución, hubiera un criterio de Gobierno y una actitud transaccional. No lo logró. Salió del Gobierno el 11 de octubre tras aprobarse el artículo 26. Desde fuera, no dejó de contribuir a reformar la Constitución, ya que no pudo intervenir para evitar sus errores. El Gobierno provisional, en su estatuto, aprobó la libertad de cultos. Habría que ir más allá de la Constitución de 1869.

El artículo 26 fue un grave imprevisto. Nadie creía que se llegara a eso. Alcalá Zamora reconoce el mérito de la intervención de Azaña el 13 de octubre, que evitó mayores daños. Alejandro Lerroux dejó libres a los diputados radicales. Estaba en Madrid, pero no intervino.

Se consensuó una fórmula, pero no se escogió el recorrido adecuado. No fue desde la izquierda a la derecha. En su camino se fue agravando. La derecha dio como base inicial la máxima concesión que podía hacer. El texto votado era menos sectario que los anteriores. Azaña logró una mayoría en torno a su propuesta. Se votó con entusiasmo. Se creyó una victoria de las izquierdas, incluso sobre la derecha liberal de Alcalá Zamora y de Miguel Maura.

Esa sensación de victoria frenó la protesta de la izquierda. Se salvó el "espíritu genuinamente republicano". El 14 de octubre fue una jornada de paz. Ese día fue además "precursor de muchos años de lucha”. Comentó esto con ironía

Al acabar el debate, echadas las cuentas, el balance arrojaba un resultado muy negativo. Se obstruyó el acercamiento de las fuerzas que estaban fuera del la República. Se rompió la concordia entre los partidos republicanos. Se debilitó a los del centro, que hubieran podido atraer a los de la derecha, a las clases conservadoras. Los católicos fueron empujados a los partidos enemigos del régimen, abriendo este a un debate, que se creyó resuelto.

El artículo 26 agravó lo previsto en el 125: no sería posible una reforma de la Constitución, orgánica, no ideológica, sino experimental, limitada y prudente. El único beneficio fue para heterodoxos, librepensadores, anticlericales, que salieron satisfechos. Ninguno podía creer que su derecho al respeto de su conciencia había estado amenazado. La extinción de la Compañía de Jesús y el

31 “Inventario objetivo de cinco años de República (4)”), La Nación 21 julio 1936, “Artículos publicados en el diario "La Nación” (Buenos Aires, 1936-1939), Alcalá Zamora, N. 2003, 26-29. En el balance de la República incluye Alcalá Zamora lo que llama "la alegría de la República", en estas jornadas iniciales. "Lo que salvó la República”, La Nación, 9 diciembre 1938, Ibídem 192.

Hispania Sacra, LXIV, Extra I, enero-junio 2012, 69-148, e-ISSN: 1988-4265, doi: 10.3989/hs.2012.027 
secuestro de sus bienes, por su menor cuantía, era un remedo de la desamortización. Poco negocio y mucho expediente complicado. ${ }^{32}$

Recorramos los hechos. Se acudió a unos expertos que en junio tenía elaborado un texto. Era una comisión asesora. No vinculaba a las Cortes. ${ }^{33}$

El 14 de julio Alcalá Zamora, como presidente del Gobierno Provisional, inauguró las sesiones de las Cortes Constituyentes. ${ }^{34}$ La heterogénea composición de los diputados elegidos, "una cámara de inexpertos", según Alcalá Zamora, dio lugar a muchos de los excesos que se cometieron en los debates. ${ }^{35}$ Esto se agravó porque el Gobierno no presentó ponencia. El dictamen de la Comisión Jurídica Asesora no fue tenido en cuenta por la Comisión elegida por los diputados:

La emotiva descripción del ceremonial, hecha por Azaña, ${ }^{36}$ no se cumplió cuando de la fiesta se pasó a la labor parlamentaria. En las sesiones que siguieron fue creciendo la decepción en personas como Alcalá Zamora y Ortega y Gasset, en quien llegó a pensarse como primer Presidente de la República.

Tras ratificar su confianza al Gobierno, la Comisión, encargada de elaborar la Constitución, comenzó sus trabajos. Los cinco socialistas, los cuatro radicales, los tres radical-socialistas y los dos de Esquerra Republicana, sumaban 14, mientras que los representantes de las minorías eran 7. Entre estos se incluye uno de Acción Republicana, otro de la ORGA y uno del Partido Federal. Afines a las posiciones tradicionales de la Iglesia, José María Gil Robles y Jesús María García Leizaola. Por el Partido Republicano Progresista Juan Castrillo Santo, y Alfonso García Valdecasas representaba la Agrupación al Servicio de la República. Mariano Ruiz-Funes, a Acción Republicana. ${ }^{37}$

${ }^{32}$ Verdoy, A. 1992. "La incautación del Seminario Pontificio de San Antonio de Padua de Comillas durante la Segunda República, 1932-1935”. Miscelánea Comillas: Revista de teología y ciencias humanas: L/96-97: 259-290. Ejemplar dedicado al I Centenario de la Universidad Pontificia Comillas 1892-1992) y Verdoy, A. 1995. Los bienes de los jesuitas: disolución e incautación de la Compañía de Jesús durante la Segunda República Madrid, Trotta: 442.

${ }^{33}$ Anteproyecto de Constitución de la República Española que eleva al Gobierno la Comisión Jurídica Asesora, Madrid julio 1931. La integraron Matilde Huici.-Manuel Pedroso.-Agustín Viñuales-Javier Elola.Francisco Romero Otazo.-José Antón Oneca.-José Sanchís Banús.-Alfonso García Valdecasas.-José CastáN. Arturo Rodríguez Muñoz.-Valeriano Casanueva.-Antonio de Luna. El texto y los votos particulares están editados en:

http://www.cervantesvirtual.com/servlet/SirveObras/12482192022352628532846/p0000001.htm

34 DS/CC 1 (14 julio 1931) 2-3 y Extracto en Simeón Vidarte, J. 1976.Las Cortes Constituyentes de 1931-1933. Testimonio del Primer Secretario del Congreso de los Diputados, Barcelona, Buenos Aires, México D.F. Dimensiones Hispánicas, 54-56

35 Alcalá Zamora vio que el debate constitucional acabó con "la espléndida y alentadora generosidad del 12 al 14 de abril". Entonces se hizo una revolución en paz. Desde julio, eso cambió. La Constitución y las leyes posteriores fueron "de guerra". Fue aquella, técnicamente un texto prolijo, minucioso, y sectario, rígido y casi irreformable desde el punto de vista político. Debió ser una Constitución para solucionar los problemas. Bastaba un texto flexible, conciso, común, transaccional y, de ese modo, duradero. "Orígenes y obras de las Constituyentes", julio 1936, La Nación, Buenos Aires.

${ }_{36}^{36}$ Azaña, M.1968. Memorias políticas y de guerra, tomo IV, México, Oasi: 28-29.

37 Se ha comentado que la actuación de Alcalá Zamora en el debate le planteó serios dilemas, Alcalá Galve, A. 2006 294-300. 
El presidente del Gobierno Provisional dijo que la revolución que trajo la República debería ser la última de la revoluciones política y cerrar un ciclo Fue la primera revolución social y también debería ser la última.

Hay un tiempo para la rebelión, pero, al llegar al poder, la libertad se hace "gobernante" y ya "no tiene derecho a colocar una valla frente al dolor de los oprimidos" para frenar sus reivindicaciones.

La llegada de la República fue un "prodigio pacífico", pues se salvaron la vida y fortuna de los ciudadanos y el principio de autoridad.

No fue una revolución violenta en los medios, ni extremista en sus tendencias. La revolución violenta era un anacronismo. Una extremista era incompatible con la cohesión y subsistencia del Gobierno. Su gestión dejaba camino abierto y expedito para todas las reformas y todos los avances que la sociedad española decida.

Había cosas pendientes. No había hecho el Gobierno una política monetaria. Quebrantos y sacrificios deberían ser sancionados por la soberanía nacional, en una Asamblea Constituyente. Tampoco se realizó una ordenación definitiva de la organización municipal y provincial, que deberá ser obra recogida en la Constitución.

No han sabido acertar los ministros en el ritmo, unos lo juzgaron lento y otros acusaron al Gobierno de actuar como una dictadura, imponiendo medidas y reformas con excesiva prisa.

El Gobierno preparó sus medidas en la cárcel y en el exilio. Mantuvo su coherencia porque los ministros comprendieron que "no se gobierna con la intransigencia férrea de la convicción personal, con el ideario del partido al que se pertenece". Se examina en conciencia la posibilidad de concordia y, para darle expresión aritmética, se descomponen los programas en factores y con los comunes "se obtiene el máximo divisor, que permite la eficacia de un Gobierno heterogéneo".

Deriva de aquí la idea de que la República es una fórmula de interés nacional que solo, en momentos de desviación sectaria, de apasionamiento, de guerra civil, declara enemigos y ve enemigos dentro del país". La República es una institución que, en sus límites, se identifica y que, solo en la fórmula, se diferencia con la suprema conveniencia nacional". ${ }^{38}$

Las Cortes constituyentes iniciaron sus trabajos el 14 de julio de 1931. Cayeron en la tentación de transformarse en una Convención: un tribunal político que juzga las responsabilidades de la monarquía, desde el Rey “a las últimas concejalías". ${ }^{39}$

Ante una iniciativa de Niceto Alcalá Zamora, el Gobierno, por unanimidad, se opuso a ese propósito. El encargado defender lo decidido debía ser Fernando de los Ríos, ministro de Justicia. Dijo

38 Alcalá Zamora, N. 1979 "Sesión de apertura de las Cortes constituyentes”, 14 julio 1931 y "Gestión del Gobierno Provisional de la República y la resignación de sus poderes ante las Cortes”, 28 julio 1931 , 259 y 271-284

${ }^{39}$ El acta de acusación contra Alfonso de Borbón, 12 de noviembre de 1931, DS/CC 73 (12 noviembre 1931, 2311 y apéndice 9 1-5. La actuación del Tribunal que ha de juzgar las responsabilidades de la Dictadura quedan recogidas en el Diario de Sesiones. Pueden verse el Índice de la Legislatura 1931-1933, Responsabilidades. La sentencia de esta comisión parlamentaria actuando de Tribual, se dictó el 7 de diciembre de 1932, DS/CC 271 (7 diciembre 1931) 10013-10018. 
no poder hacerlo porque se lo prohibió el grupo socialista. Se pensó en Miguel Maura, pero se temió que su habilidad y claridad levantaran a la mayoría de las Cortes contra el Gobierno.

Por eso intervino Alcalá Zamora. Consideró ese discurso el más honroso de su vida. Fue escuchado con atención. Fue además eficaz. Se descartó la sanción arbitraria y los procedimientos anormales. La convención se redujo a una "parodia" de proceso contra el ex rey, ya condenado por el país. Hubo pocas inhabilitaciones y destierros. Hubieran bastado para eso el código penal y la jurisdicción ordinaria...

Todos debían tener tacto para contribuir a que nada se malograra. ${ }^{40}$ Comisionado por los otros ministros del Gobierno provisional, intervino el 20 de agosto en el debate sobre las "Normas de Actuación de la Comisión de Responsabilidades". Asumió ese riesgo, pues "gobernar no es cosechar aplausos, eludir problemas, aprovechar facilidades, es enfrentarse con las dificultades, correr el riesgo y cumplir el deber. Y por eso intervengo". ${ }^{41}$

"No caí del poder, pero si hubiera caído, el resultado de paz y de regularidad jurídica valía de sobra el sacrificio, como valió el riesgo". ${ }^{42}$

El 29 de julio de 1931, Alcalá Zamora informó a las Cortes constituyentes sobre la gestión del Gobierno Provisional desde el 14 de abril. Al concluir dijo que la Cámara designase solo al presidente y que no debatiese el nombramiento de cada ministro. Y terminó con esta autoconfesión:

"Mi inconveniente es una falta total de flexibilidad para las combinaciones; mi ventaja es la claridad de ella. Si alguien me vota, sepa que el Gobierno es éste; sin una variación, tal como está constituido". ${ }^{43}$

Comenzó su rendición de cuentas destacando que se quiso que el ceremonial de este acto fuera "sobrio, de solemnidad silenciosa, de emoción muda, en que se reflejara, pura y escueta, la austeridad republicana”. Quería imitar a quienes iniciaron la historia constitucional de España en 1812.

Bajo la influencia de la fiesta de la República, con su desfile militar, en el momento de abrir sus sesiones las Cortes constituyentes, comentando el discurso que, como presidente del Gobierno Provisional, pronunció Alcalá Zamora, El Liberal subrayó el 30 de julio que una Cámara, con predominio de la izquierda, le manifestó el respeto, la consideración y el afecto de todos, "por su talento, por su austeridad, por su acrisolada honradez, por la importante aportación que hizo a la República". ${ }^{44}$

Sabemos que siendo presidente del Gobierno provisional solía reunirse en su casa de Martínez Campos. Lo hizo el 14 de septiembre de 1931 con Tedeschini y Vidal i Barraquer. Dejó en sus Memorias que no quería presidir la República, atendiendo a las ventajas "suntuarias y materiales del

40 Alcalá Zamora-Vidal i Barraquer, 6 agosto 1931, 1971 Arxiu Vidal i Barraquer... 186.

41 Alcalá Zamora, N. "Normas de Actuación de la Comisión de Responsabilidades", 20 agosto 1931, DS/CC 24 (20 agosto 1931) 517-523 y 1979. 286.

42 Alcalá Zamora, N. 1976. 178-179. Su actitud ante el juicio y condena de Alfonso XIII, 179-180

${ }^{43}$ En Simeón Vidarte, J. 1976. 92-97

${ }^{44}$ DS/CC 10 (28 julio 1931) 168-175 y Discursos...256 y 256 y 257. 
cargo", pero con pocas preocupaciones y asumiendo de forma automática sus deberes, siendo mero buzón y estampando la firma a lo que le presentaba el jefe del Gobierno.

Quizás esa abnegación, ese desapego al poder, explique lo que ha extrañado tanto: no dudó de dimitir cada vez que vio en peligro su lealtad personal o palpó la deslealtad de quienes eran sus compañeros de Gobierno. ${ }^{45}$ ¿Extraña y hasta merece reproche una persona que considera que su conciencia no está en almoneda? ${ }^{46}$

El 17 de noviembre regresó de Priego de Córdoba. Al día siguiente fue al despacho oficial de Azaña en el ministerio de la Guerra. Hablaron de la organización de la casa del presidente. Nada de boato, de adquirir edificio o finca para su residencia oficial. Ira al Palacio Nacional a despachar y seguirá viviendo en su domicilio. ${ }^{47}$

\section{EN LAS CORTES CONSTITUYENTES}

El 23 de junio de 1931 dijo en la campaña electoral que las Cortes constituyentes tendrán que afrontar estos tres problemas: religión, unidad nacional y propiedad de la tierra. Ninguno de ellos puede resolverse establemente "sin una transacción noble en el cual no se imponga el criterio de las Derechas, pero que sea aceptable y aceptado, por ese criterio gubernamental, expansivo, generoso, noble, por esa amplia comprensión con ellas.

Se necesitaba un partido que pueda decirle a los republicanos:

"hasta ahí llega la libertad, que nos es común, la defensa de la República, que nos interesa por igual. Y se pueda volver a los otros y les diga: esa protesta, ese escándalo, esa perturbación que pedís, demandando la permanencia de lo medieval, eso no es religión, sino fariseísmo; eso no es iglesia, sino teocracia; con eso no podemos transigir nosotros; y nosotros, que no somos fanáticos como vosotros, somos ortodoxos, como el primero que lo sea".

Si falta esta colaboración de las fuerzas gubernamentales, se abriría paso una imposición, sin arraigo y artificiosa de las tendencias extremas y seguiría abierto el proceso constituyente. Se llegaría a una Constitución inadaptable, discutida, "con todo el peligro... el inmenso peligro vital de una cicatrización aparente bajo la cual surge el problema, mina el daño y amenaza el peligro. Este es el problema" 48

Sobre el artículo 1 de la Constitución, Pedro Massa afirma que, con la intervención de Alcalá Zamora, triunfaron la claridad, la honradez política, el patriotismo. "¡Cuánto deben a ese hombre ejemplar la República y el Parlamento!". 49

${ }^{45}$ Alcalá Galve, A. 2006. 329-330 y 377.

${ }^{46}$ Diego Martínez Barrio comenta el discurso de Alcalá Zamora en el debate sobre la cuestión religiosa. Expuso sus ideas e hizo sus previsiones sin "dramatizar", con gesto noble, "como si el desdén por la ceguera de los contradictores fuera castigo suficiente a la culpa". Esta cita de la Memorias de Martínez Barrios, Ibídem 335336. la posición de Alejandro Lerroux, y Azaña, Ibídem 341-345.

${ }^{47}$ Mantuvo esa decisión, que fue muy bien vista por el Conde de Romanones, Por Ángel Ossorio y otros, Ibídem 380 y 343.

48 "Mitin de Propaganda Electoral", Jaén 23 junio 1931, Alcalá Zamora, N. 1979 547-548.

${ }^{49}$ Pedro Massa, “Asomado a la tribuna. Ímpetu y reflexión”, El Liberal, 18 septiembre 1931, en Alcalá Zamora, N. 1979. 308. 
Las elecciones a Cortes Constituyentes fueron las mejores celebradas en España. Afirmado eso, Alcalá Zamora decía que los elegidos, en algún problema, tendían ser más radicales que el país. El Gobierno deberá seguir demostrando "tino". "Hoy por hoy, parece probable que en todo predominen soluciones transaccionales", de mayor concordia.

El Gobierno provisional no tenía posición respecto a la Constitución. Lo dijo Alcalá Zamora en su intervención el 17 de septiembre de 1931. No quería ser la "guía absoluta de una Cámara dócil". La razón es que la discrepancia en el seno del Gobierno sobre los problemas más importantes no era "bizantina sino fundamental... lo que nos separa irreductiblemente es todo lo hondo y recio en la entraña en la Constitución: monopolio o libertad de enseñanza, condenación o garantía de la propiedad privada, posibilidad u obstáculo para el Concordato, Senado o Cámara única, criterio unitario o sistema federal". ${ }^{0}$

Era previsible el resultado: una Constitución de "izquierdas". Alcalá Zamora fue felicitado al defender su posición. Se rechazaba, porque los socialistas no podían ceder, estaban obligados a mantener el criterio de la izquierda. Los pujos de la derecha se estrellaban "contra el ambiente de la República en el parlamento y fuera de él". 51

Alcalá Zamora dijo, siendo ya el Presidente de la República, que la Comisión Constitucional se atuvo a "orientaciones envejecidas o inexpertas". "Predominó con frecuencia, ante la discusión y frente a las enmiendas, la voluntad impresionada y variable" de la Comisión. Creían que era la mayoría, pero esta era "accidental" y estaba en minoría frente al resto de la Cámara. Algunos artículos fueron una excepción. Algunas enmiendas, muy pocas, se aceptaron El discurso preliminar al texto de la Comisión no aportó claridad para interpretarla. Faltaba la exposición de motivos que precede a todas las leyes.

Había influencias extranjeras. La de Roosevelt, en la orientación federable. La del radicalismo francés, de inicio del siglo y ya superado, en el anticlericalismo. Fue ajena al momento, la posición pacifista, presente en el título preliminar, artículos 7 y otros más afectados por esa posición. Hay una apuesta colectivista, socializante, que recuerda la Constitución francesa de 1848. La hegemonía de una Cámara, "única y omnipotente" desnivela la Constitución.

Los problemas previstos se agrandaron. Hay también influencia de la Constitución francesa y alemana en la regulación del poder del presidente. De México se copió el recurso de amparo y, sobre todo, "el encono en la lucha religiosa; el deseo reconvertirla en una guerra civil crónica, encarnizada, de exterminio de aquel sentimiento (religioso) y, en definitiva, de no cambiarse el rumbo, del país mismo".

"Cada suceso, cada periodo de tiempo durante mi mandato, me convencieron de que nuestra ley fundamental era la menos viable que había tenido España y la menos viable entre las

50 Alcalá Zamora, N. "Proyecto de Constitución”, DS/CC 40 (17 septiembre 1931) "Normas de Actuación de la Comisión de Responsabilidades”, 20 agosto 1931, Alcalá Zamora, N. 1979. 983-987 y 309-310. Su defensa de la existencia del Senado, "Senado", 63 (27 octubre 1931) 1947-1955 y 1979 373-388

51 “Comprensión y estudio", El Liberal, 18 septiembre 1931, recogido en Alcalá Zamora, N. 1979. 373 
que hoy rigen la suerte de otros pueblos. La reforma, por tanto, era, y es, una suprema necesidad de paz, de orden y de convivencia". 52

Sin tener un nivel alto de ilustración, Alcalá Zamora reconoce a las Cortes constituyentes un alto valor moral y sentimental. Las únicas sorpresas fue la presencia de personalidades destacadas profesionalmente, nuevas en la política.

La primera carencia fue que no representaron "la estable, verdadera y permanente opinión española". La responsabilidad no fue del Gobierno ni de los diputados, sino de las derechas. Se abstuvieron y no supieron ver cuál era su conveniencia política. Por eso no pudieron formar una mayoría.

Todos debían tener tacto para contribuir a que nada se malograra. ${ }^{53}$ Comisionado por los otros ministros del Gobierno provisional, intervino el 20 de agosto en el debate sobre las "Normas de Actuación de la Comisión de Responsabilidades". Asumió ese riesgo, pues "gobernar no es cosechar aplausos, eludir problemas, aprovechar facilidades, es enfrentarse con las dificultades, correr el riesgo y cumplir el deber. Y por eso intervengo". ${ }^{4}$

Apartaron a Miguel Maura y Alcalá Zamora. ${ }^{55}$ Quisieron anular cualquier fuerza republicana de derechas. La República era suya. Ante su victoria, rompieron la alianza electoral. Creyeron que eran la representación de la opinión. Era un error, pero justificable, porque las elecciones fueron limpias, salvo en sus feudos de la manipulación el sureste y el noroeste.

Sumada su escasa preparación con su sentido de la justicia, aquellas Cortes fueron "las más necesitadas de guía". Por eso fue un error la abstención del Gobierno. Esa opción se acentuó cuando lo presidió Azaña. En torno a él se formó una mayoría compacta, que resistió todas las pruebas en los dos años siguientes. En esa nueva mayoría mandaron los radicales socialistas, que pujaron siempre por ganar en extremismo a sus aliados, como sucedía ya dentro del partido, combativo, idealista...Fue una fuerza desordenada y sin norte. Actuó por impulsos irreflexivos. Gozó "del influjo más efímero, decisivo y funesto que haya tenido ningún otro en España".

Este yerro de las izquierdas prevaleció gracias a la inacción de las derechas. Aprobado el artículo 26, repitieron la opción por "el mal mayor". Alcalá Zamora recuerda el comentario de un diputado agrario. Viajaba en su tren un extranjero. Les avisó: en los parlamentos, el ausente jamás tiene razón.

En resumen, la Constitución se planteó a espaldas de la realidad nacional. ${ }^{56}$ Hubo quienes creyeron que la República era una revolución social, que todo lo legitimaba. No cuentan votos cuando ganan y dicen que ellos son el pueblo y hacen lo que este desea. Para ellos oponerse a sus designios o

52 "Los defectos de la Constitución de 1931 y "Tres años de experiencia constitucional” Alcalá Zamora, N. 2002. 25-30 y 40-41. Se editó tras la crisis del 7 de abril. Su propuesta de reforma, del 8 septiembre 1935, Ibídem 50-54. Sobre esto, vid, Alcalá Galve, A. 2006. 368-376.

${ }_{53}$ Alcalá Zamora-Vidal i Barraquer, 6 agosto 1931, 1971 Arxiu Vidal i Barraquer. 186.

54 Alcalá Zamora, N. "Normas de Actuación de la Comisión de Responsabilidades", 20 agosto 1931, DS/CC 24 (20 agosto 1931) 517-523 y 1979, 286.

${ }^{55} \mathrm{La}$ oportunidad para que se apartaran del Gobierno fue el debate sobre la cuestión religiosa. La aprobación del artículo 26 abrió la crisis del Gobierno y salieron Alcalá Zamora y Miguel Maura el 14 de octubre.

56 "Los defectos de la Constitución de 1931 y Tres años de experiencia constitucional”, Alcalá Zamora, N. 2002. 15-24 y 32 .

Hispania Sacra, LXIV, Extra I, enero-junio 2012, 69-148, e-ISSN: 1988-4265, doi: 10.3989/hs.2012.027 
simplemente apartarse para no correr su suerte o ser cómplices de sus planes, era romper el compromiso. Así calificaron la dimisión de Alcalá Zamora. ¿Cuál? No abrir una crisis de Gobierno durante el debate. Hubo más compromisos. Hoy sabemos que faltaron a ellos todos los que en esos momentos actuaron como mayoría "mecánica” que impuso "su Constitución”.

Alcalá Zamora abandonó el Gobierno para trabajar por la revisión de lo que estaba siendo aprobado. Parece que se quedó solo. En cuanto a la revisión constitucional, echando números, no es exacta la acusación. En cuanto al futuro de su pretensión de hacer viable la República con una Constitución adecuada, parece que estaba bien acompañado por los votantes y por uno de los partidos de la mayoría. Los primeros cambiaron el panorama político en las elecciones de noviembre-diciembre de 1933. Unos meses antes, en junio, el Partido Radical abandonó la alianza y dejó a Manuel Azaña solo con los socialistas y los radical-socialistas.

Su decisión de salir del Gobierno nada tenía que ver con la retórica de quienes sentenciaron que iba por el camino "contrario a la revolución que el pueblo deseaba hacer". Ni es verdad que reclamara una Constitución a su gusto". ${ }^{57}$

Declaró el 10 de octubre por qué salía del Gobierno: se consideraba fuera de la Constitución que estaba aprobándose y, por tanto, necesitaba ser libre para postular su reforma.

Creyó que exteriorizar esa decisión beneficiaba a la paz interior de España y a la República, "ofreciendo, dentro de esta, a la parte sensata y liberal del catolicismo español un amparo por vías legales, que le sustraiga a todas las actuaciones de la desesperación". Si los católicos intransigentes apelaran a la violencia, desde su cargo de presidente no tendría "la autoridad necesaria para reprimir las demasías en la defensa de un derecho atropellado. Si, desde el otro extremo, quisieran rebasar lo aprobado, yendo contra le Ley, sentiría que le faltan asistencias para desalentar o frustrar ese propósito.

Como buen liberal, al respetar su conciencia, reconocía también la capacidad de las Cortes Constituyentes para desaprobar la conducta de un miembro del Gobierno. Había sucedido ya y quedó confirmado con la intervención de Azaña el 13 de octubre. ${ }^{58}$ Había agravado el texto de la comisión. Había aquí una alusión a lo que había sido objeto de conversaciones los días 27 y 29 de agosto.

El párrafo más sutilmente duro es la denuncia de la solidaridad masónica. Sin negar los respetos personales, las Cortes "para depositar confianza, reputan un obstáculo la creencia católica y una garantía otras muy distintas filiaciones, a las cuales, en uso de mi libertad y por el firme propósito de no hipotecarla, no estoy sometido".

No quería que la sociedad española -Alcalá Zamora habla de las "masas"- lo juzgaran, por apariencias, "aferrado sin dignidad y por codicia, al poder". No quería que tuvieran que echarlo de él, como si se hubiera resistido a marcharse voluntariamente.

${ }^{57}$ Estas acusaciones contra Alcalá Zamora, Martínez Saura, S. 1999. Memorias del Secretario de Azaña. Edición y Prologo de Isabelo Herreros Martín-Maestro. Nota preliminar de Paloma Zubieta López, Barcelona, Editorial plantean, Colección España Plural: 106-107.

${ }^{58}$ DS/CC 55 (13 octubre 1931) 1666-1672. Manuel Azaña dijo que este discurso era la posición de Acción Republicana. 
Termina manifestando su afecto, su gratitud y su disposición a "seguir trabajando, cuando pueda, por la República y por España". 59

Uno de sus empeños, durante el debate, fue defender la existencia del Senado. La Constitución de la República Española iba a ser una excepción en el conjunto de las democracias parlamentarias. Las Cortes eran unicamerales. Dejar la "revisión de las leyes, en manos solo del Presidente de la República es un riesgo. Si es una persona aventurera y ambiciosa, los "temporales" políticos abonan la aparición del poder personal; si es tímido para oponerse a la Cámara, entonces no es enemigo de la Cámara, ciertamente, pero hay que preguntarse de dónde y cuándo vendrá quien termine eclipsando la libertad republicana.

La solución de elegir a un hombre prudente, abnegado, generoso, esclavo de su palabra, fiel a las promesas, ajeno a cometer demasías, nada resuelve. Tarde o temprano, por deber de conciencia, por patriotismo, creyendo que no puede compartir las responsabilidades de la Cámara, dimitirá. En ese caso, la alternativa es reemplazarle y que venga alguien cuya audacia sirva de "contrapeso" a la Cámara, o que llegue una persona abúlica, que "con ella se hunda", pero "este republicano de año y medio no quiere echar sobre su conciencia" esa tremenda responsabilidad. ${ }^{60}$

Los problemas que plantea la Constitución al derecho los expuso Alcalá Zamora el 26 de noviembre de 1931 en la inauguración del curso 1931-1932, como presidente de la Academia de Legislación y Jurisprudencia el 26 de noviembre de 1931.

Este fue su elenco: crecimiento del volumen legislativo, como consecuencia de los aspectos que se incluyen la Constitución. Hay un cambio en el poder legislativo que marca unos rumbos nuevos. Impuesta la unidad legislativa, el poder legislativo regional renace ahora con la Constitución.

Recuperada la posibilidad de que las personas jurídicas fueran sujeto de derecho, incluido el de propiedad, ¿se va a negar a la Iglesia si se acepta para "entidades laicas?

En relación con los derechos individuales, se prevé una rebaja en la edad de emancipación y en el derecho de sufragio, con su impacto en la patria potestad. Quedaran derogadas las restricciones por razón de sexo y de estado conyugal. En esta misma dirección va el reconocimiento legal de la profesión religiosa. La legislación permitiendo el divorcio tendrá efectos en la duración del estado de ausencias en lo que afecta a los familiares del desaparecido.

El internacionalismo, recogido en la Constitución, planteará la ampliación de la doble nacionalidad.

Alcalá Zamora analizó también los efectos que tendrá la Constitución en el derecho de propiedad y de obligaciones y en el derecho sucesorio.

${ }^{59}$ Texto en Alcalá Galve, A. 2006- 361-363. Sobre el extremismo sectario en las Cortes constituyentes, denunciado por Ortega, Ibídem 373.

60 Alcalá Zamora, N. "Senado", 27 octubre 1931, 63 DS/CC (27 octubre 1931) 1947-1955 y 1979. 373388. la cita 388. La posición de Alcalá Zamora en defensa de la existencia de una segunda Cámara, como instrumento de estabilidad y para garantía del ejercicio de la presidencia de la República, Alcalá Galve, A. 2006. 347-357. 
Mucho más inmediatas y patentes serán las consecuencias en el derecho administrativo, citando expresamente la aparición de las administraciones locales y las de las autonomías. La importancia de la administración "consultiva" y de los Consejos...

Vendrá un predominio de lo estatal y de lo social con efectos en la expropiación y el dominio público. Examinó las variantes y novedades que la Constitución introduce en el derecho procesal y en otras ramas, como el derecho canónico, en el penal y en el internacional.

Quiso, de una manera rápida y hasta apresurada, presentar un avance del estudio que debe hacerse para "iniciar una visión sistemática, conjunta orgánica de la obra constitucional, relacionada con la totalidad del ordenamiento jurídico". ${ }^{61}$

\section{PLENA LIBERTAD DE CONCIENCIA Y DE CULTO}

Quienes querían seguir aquí una vía semejante a la México, olvidaron que allí hubo una Guerra Civil, "en defensa de la libertad religiosa" desde 1926 a 1929. Cuando el 21 de junio de este año, Emilio Portes Gil hace su declaración, precedida por la de Elías Plutarco Calles en abril de 1926, se vio los problemas que planteaba esa rectificación del Gobierno de la Federación Mexicana. ${ }^{62}$

Cuenta Alcalá Zamora que un personaje de la masonería le pidió en septiembre de 1931 que se declarase "extranjeros a todos los obispos, canónigos, beneficiados, párrocos, coadjutores, frailes y monjas de España". ${ }^{63}$ Iba más allá que en México.

Se violó en la Guerra Civil de España la neutralidad religiosa del Estado. ${ }^{64}$ Se persiguió, de forma sanguinaria e implacable, el culto católico y a los católicos. Muchos tuvieron que aceptar "cuantiosas y delictivas exacciones" para salir de España y salvar su vida. La pertenencia al Frente Popular fue un título privilegiado para ejercer funciones públicas. ${ }^{65}$

61 "Repercusiones de la Constitución fuera del Derecho Político", Madrid 26 noviembre 1931, Alcalá Zamora, N. 1979. 550-575.

${ }^{62}$ Una clave para entender esa crisis, que atravesó la sociedad y la Iglesia Católica en México, está en un escrito de Manuel Mestre Chigliazza a Álvaro Obregón, que había presentado su candidatura a la presidencia. La literatura subvencionada y la prensa controlada querían ocultar la realidad del país. Una clase dirigente, que apelaba siempre a las "reivindicaciones del proletariado, vivía lujosamente ante un pueblo que veía crecer la carestía. Hacía ostentación de sus privilegios: automóviles oficiales y grandes sueldos para unos cargos que eran fruto de una era política, que privilegiaba la incompetencia. Como librepensador, denuncia que la legislación es antiliberal y opresora. "iLegislar sobre el número de sacerdotes cuando hay separación de la Iglesia y del Estado, prohibir la enseñanza religiosa en los colegios privados, amordazar la prensa brutalmente para que $n$ librepensador, denuncia que la legislación es antiliberal y opresora. Una copia, mecanografiada ASV Arch.Deleg.Messico Busta 73 fasc. 381 76-77.

63 "Los defectos de la Constitución de 1931 y Tres años de experiencia constitucional", Alcalá Zamora, N. 2002. 94.

64 "El Estado español no tiene religión oficial" (Artículo 3)

65 "No podrán ser fundamento de privilegio jurídico: la naturaleza, la filiación, el sexo, la clase social, la riqueza, las ideas políticas ni las creencias religiosas" (artículo 25) y "Todos los españoles son iguales ante la ley" (Artículo 2). 
Otra vez Alcalá Zamora recordó el acuerdo que el Gobierno Provisional alcanzó en agosto de 1931 sobre la cuestión religiosa. Se respetaba la plena libertad de conciencia y de culto. Pudo llegarse a un Concordato, porque la actitud del nuncio Federico Tedeschini, de la Santa Sede, fue leal y abierta hacia los cambios. En la votación de aquella reunión en el ministerio de Hacienda, se aprobó el acuerdo por once contra uno, Indalecio Prieto. Este mantuvo la cordura en el debate constitucional, una vez salvada su conciencia. No se cumplió lo convenido, dice Alcalá Zamora, con discreción, porque algunos ministros "cambiaron de indumentaria y de nombres". Su condición de masones les obligó a faltar a su palabra. ${ }^{66}$

Serio y urgente problema no podía resolverse con el mismo simplismo con el que se planteó la reforma agraria. En plena crisis económica, ignorada por estos prometeos de la revolución, podía plantearse una reforma expropiando sin indemnización.

Estaba esa reforma prevista. La agitación social la aceleró. Alcalá Zamora tuvo que interponer ante los otros ministros su autoridad jurídica. Había escrito sobre la expropiación forzosa. Destacó el quebranto del crédito que suponía expropiar sin indemnización. Una indemnización generosa reducirá la oposición a esa medida. ${ }^{67}$

Un ejemplo de ese desordenado modo de construir la Constitución fue incluir en ella el divorcio. Su lugar es el código civil. Desde el punto de vista de la Iglesia los católicos no deben considerar que el divorcio sea vincular. Se limita a la separación de cuerpos y de bienes. No es obligatorio contraer nuevas nupcias. Por eso el asunto de la disolución del vínculo no entra en una ley de divorcio. La autorización del divorcio lo único que hace es ahorrar trámites y otros problemas a quienes desean separarse. En todo caso, debe asegurarse que la indisolubilidad de matrimonio se mantenga para los sectores sociales con menos medios. ${ }^{68}$

Era esto último otra prueba de la sensibilidad de Alcalá Zamora. Gaspar Mermillod, obispo de Lausanne-Genève citó en el Congreso Internacional de Lieja esta anécdota de Cavour. Al enjuiciar una ley estableciendo el régimen matrimonial, dijo: "Io non l'acceterai mai, perché non è punto una legislazione liberale: ogni legge liberale deve proteggere la debolezza, e questa legge non protegge punto la donna". 69

Era Alcalá Zamora especialmente sensible ante una mentalidad totalitaria, excluyente. En la solución de la cuestión religiosa, es decir, del estatuto de la religión en la República, se infiltró "un rencor anticlerical, jacobino, "que a veces alcanza violencia de hostilidad, poco disimulada, contra la paz religiosa". 70

"Sólo es fuerte el que está sólo". Alcalá Zamora no se siente así cuando se levanta a defender su postura en el debate sobre el estatuto constitucional de la religión. Lo había aprendido años antes. El 26 de mayo de 1922 hubo una crisis. Alcalá Zamora dimitió como ministro de la Guerra. Había un

66 "Régimen político de convivencia en España, 1945 Alcalá Zamora, N. 2000. 109-110. Apareció en Buenos Aires, Editorial Claridad, 1945. En esta edición 67-233. Confiesa que fue escrito entre febrero y marzo de $1937,71$.

${ }^{67}$ Alcalá Zamora, N. 1976. 172-173.

68 "Los defectos de la Constitución de 1931 y Tres años de experiencia constitucional". Alcalá Zamora, N. 2002. 104-105.

${ }^{69}$ Soderini, E. 1932 Il Pontificato di Leone XIII, tomo I, Milano, A. Mondadori: 347.

70 Inventario objetivo de cinco años de República (9)" La Nación, 3 septiembre 1936, "Artículos publicados en el diario "La Nación” (Buenos Aires, 1936-1939), Alcalá Zamora, N. 2003. 57. 
enfrentamiento entre él y Santiago Alba, ministro de Estado. Por medio, Marruecos, donde los dos ministros tenían responsabilidades no bien delimitadas. Usó una expresión, aun forzando su significación, que parece usada entre políticos entonces: el militarismo "parlamentario". 71

En lo que se venía llamando "la cuestión religiosa", defendió "la conveniencia y la paz entre todos los españoles, para cumplir el deber de todos los republicanos y a amparar el derecho de todos los católicos". Estaba solo ante la minoría vasco-navarra, cuyos diputados creen que el problema religioso es un problema político, lo usan como táctica y lo convierten en un dogma, pero no es así. Era un asunto de justicia.

La libertad de conciencia, el libre ejercicio de culto, la tolerancia plena, "es un remedio al que os acogéis en la hora de la desventura, en la hora de la derrota, y para mi es un principio que los proclamaba en la hora del Poder y como garantía de los disidentes... una diferencia enorme que nos separa incluso en los matices del sentimiento", haciendo una clara alusión a la forma en que esa minoría defendía su posición, tan ajena a la experiencia religiosa y tan pegada a los modos eclesiásticos.

Eso contrastaba mucho más cuando se veía en el "otro lado", el sentido religioso Fernando de los Ríos, Fernando Valera y Félix Gordón Ordás.

No buscaba captar, sino cumplir su deber. No le afectaba la injusticia de sus adversarios. Guardaba su serenidad "para no pedir que nos hagan justicia aquellos que tampoco la obtienen. Por eso con todas vuestra iniquidades, al tratarme así, yo soy con vosotros tolerante y comprensivo".

En su voto negativo sobre la cuestión religiosa pesaban dos motivos: su "concepto de liberalismo en relación con el interés de la República" y su concepto profesional de la ley, "de la dignidad de la ley".

Avisa que quizás es "ir demasiado deprisa" renegar del liberalismo en nombre de la República. Los votos que se obtienen con renuncia a la libertad y merma de la ciudadanía son ineficaces.

Por su experiencia jurídica conoce que media distancia enorme, de intensidad y de tiempo, entre un precepto, de implantación difícil, y su eficacia jurídica completa. Es triste el horizonte de una legislación y de un derecho que solo hallan garantía en que los preceptos no se cumplan ni obligue a ellos. ${ }^{72}$

71 “...señor Alba, hay una forma, la más arbitraria y la menos disimulada de la violencia, que suelen olvidar los ardorosos defensores del Poder civil, y es un militarismo parlamentario, en el cual la razón, que asiste a un ministro cede sin piedad a la fuerza numérica que apoya y sostiene a otro". Alcalá Zamora, N. "Crisis ministerial del 26 de mayo de 1923", y 1979. 185, 235-252

72 “Tema religioso", 10 octubre 1931, Alcalá Zamora, N. 1979. 348 y 369-370. El 21 de octubre, agradece la carta que ese mismo día le envió el religioso claretiano. "Cumplir un deber y defender convicciones de justicia, libertad y respeto para todos, lo considero cosa bien sencilla y esfuerzo fácil para quien conserva el espíritu sereno y mide, junto con los ideales de toda la vida, la conveniencia pasajera de una posición". Ibídem 371. La posición de la minoría vasco-navarra, Ibídem 348-349, la de los anti-católicos, 349-353. Su análisis del texto, Ibídem 353-365. Terminó apelando a que los católicos aceptaran la legalidad, defendiendo sus posiciones respetando la Constitución: "Fuera de la República, no; fuera del Gobierno, según decidan; fuera de la Constitución, nos imponen que estemos", Ibídem 365. Había dicho el 25 de noviembre de 1922, a propósito del 
En el 26 de noviembre de 1931, Alcalá Zamora en la Academia de Jurisprudencia y Legislación, se pregunta qué va a pasar. La respuesta es sencilla, inquietante o tranquilizadora, según quien la oiga. En síntesis: lo que queramos y lo que nos merezcamos.

“Al ponerse el poder en manos del país, al desaparecer ilusiones mesiánicas, perezosas, de incapacitados, el mismo espíritu conservador habrá de defenderse, no tras los parapetos, asaltados de antemano, sino tienen guarnición o a esta le falta la moral, sino en la batalla, en el esfuerzo de cada día y cada hora, buscando el amparo en el mismo juego de fuerzas a instituciones políticas en que ve la amenaza. Lo que se avecina es una ciudadanía, con unos Poderes distintos, porque van a ser efectivos. En el trajín de la lucha, va a perecer lo que no pueda vivir y va a salvarse lo que merezca y separa subsistir. Días de trabajo que gana y no de goce que posee, ni de ocio que hereda. Tiempos difíciles, pero tónicos $\mathrm{y}$, en definitiva, si entre lo justo se desliza el yerro, habrá remedio". ${ }^{73}$

Constituido el nuevo Gobierno, este delegó en Largo Caballero, Marcelino Domingo, Martínez Barrio y Nicolau d'Olwer para que ofrecieran la candidatura a la presidencia. Alcalá Zamora objetó su posición revisionista respecto a la Constitución. Acepó después de que su partido lo aprobó.

El nuncio barajaba varias explicaciones. Una, recuperarlo tras haberlo echado de la presidencia del Gobierno. Otra, premiarlo por su actitud serena en el debate constitucional y antes en la gestión del gobierno provisional. La tercera hipótesis podría ser descabezar a la corriente revisionista quitándole a uno de sus jefes.

Los partidos siguieron al gobierno y eso explica el resultado de la votación del 10 de diciembre. ${ }^{74}$ Alcalá Zamora fue elegido Presidente de la República por 362 votos de los 410 emitidos, en ausencia de los diputados católicos.

El Gobierno se encargó de imponer dos pequeños gestos, que podrían molestar a los católico. El primero es que el presidente emitiese su promesa, no pudiendo jurar según sus convicciones religiosas. Era una exigencia del carácter obligatoriamente laico del nuevo Estado. La segunda fue que el embajador de Bélgica actuara como decano del Cuerpo Diplomático. No pudo este asistir a la ceremonia, por varios motivos, uno de ellos su salud. El ministro de Estado tuvo que comunicar al nuncio que, como decano de los diplomáticos acreditados en España, los invitara a la toma de posesión de Alcalá Zamora. ${ }^{75}$

A poco más de un año de la proclamación de la República, en junio de 1932, tras un ejercicio táctico realizado en Campamento (Madrid) por los alumnos de las Academias Militares, habló Alcalá Zamora a los mandos asistentes.

Concluyó que la injerencia de la fuerza armadas en el Gobierno había acabado para siempre. Se cerraba una experiencia que había sido "ocasión frecuente de daño y de desastre". Era una

hundimiento de la Comandancia de Melilla en 1921, que nada le apartaría de defender lo que juzgaba justo "con serenidad y fortaleza", Ibídem 195.

${ }^{73}$ Texto en Alcalá Galve, A. 2006. 264-265.

${ }^{74} 5301$ y 5346 Tedeschini-Pacelli, 7 noviembre y 12 diciembre, ASV Arch.Nunz.Madrid 910 (1) 4-5 y

3.

755329 Tedeschini-Pacelli, 14 diciembre, Ibídem 2 286-289. La carta del embajador belga a Tedeschini, 8 diciembre, Ibídem 277.

Hispania Sacra, LXIV, Extra I, enero-junio 2012, 69-148, e-ISSN: 1988-4265, doi: 10.3989/hs.2012.027 
consecuencia lógica, en "la esencia misma del sistema" La República nació "por pacífica y libre voluntad ciudadana". No hubo requerimiento de una intervención armada "reparadora" que devolviera al país su libertad y soberanía. Esa historia de "pronunciamientos", que tanto dañó al ejército y a la sociedad, "se cerró por fortuna, definitivamente".

Había más cambios en el panorama político en este primer año. La benevolencia de la Dictadura con los socialistas debió ser pactada. Se debió ofrecer algo, a cambio de que la respuesta no fuera una huelga general revolucionaria. Cree Alcalá Zamora que esta promesa se comunicó a la II Internacional, para evitar una reacción hostil en el extranjero.

En contraste, en diciembre de 1930, fracasó la huelga general y los socialistas apostaron por la vía legal, gradual. Alcalá Zamora no comenta esto, deja constancia. Su éxito electoral en junio de 1931, que sobrepasó con creces sus expectativas, se explica por el crecimiento del PSOE durante la Dictadura. $^{76}$

La fuerza y estructura organizativa del PSOE lo convertían en el único que podía ser ministerial o revolucionario. No eligió porque le atraían los dos "impulsos". Las dos corrientes que lo dividen reclaman, eso sí, mediante la revolución, el Gobierno. A veces desde él, preparan la revolución. ${ }^{77}$

En un consejo de ministros se estudió el proyecto de Ley de Confesiones y Congregaciones religiosas. Con las modificaciones, se presentó en las Cortes. Hubiera salido aprobado, sin la oposición del partido de Álvaro Albornoz, del partido radical-socialista. Cooperaron los radicales de Alejandro Lerroux. Alcalá Zamora tuvo que llamar la atención del dictamen de una comisión, presidida por el radical Rafael Salazar Alonso. Se incapacitaba a los sacerdotes para ejercer la docencia universitaria...A ellos se sumaba el disparate de creer que era posible sustituir en tres meses la enseñanza católica en España. De todo pasó Fernando de los Ríos, afirmando que aprobada la ley, otro ocuparía el Ministerio de Instrucción Pública. Esa actitud pareció poco ética a Julián Besteiro. ${ }^{78}$ Una señal más de dos posiciones opuestas que convivían en el partido para "estar en el Gobierno"

El 1 de junio de 1933, Alcalá-Zamora visitó Bilbao, un día antes de firmar la Ley de Congregaciones Religiosas. La habían condenado el 25 de mayo los obispos. Lo hizo Pío XI el 3 de junio en la encíclica Dilectissima Nobis.

En ese contexto, denunció Alcalá Zamora a los partidos republicanos porque actuaban como sindicatos, con clientelas, pensando sólo en repartirse los votos... Por esta razón no les convenía que hubiera nuevas aportaciones a la República. Calificó esa situación como "abismos de degradación utilitaria". Impedían así que otros ejercieran su derecho y su deber de incorporarse a las instituciones, que juzgaba ya consolidadas. ${ }^{79}$

${ }^{76}$ Alcalá Zamora, N. 1976. 249-251.

77 "Los defectos de la Constitución de 1931 y Tres años de experiencia constitucional", Alcalá Zamora, N. 2002. 260. "Capacidad Internacional y Guerra civil” y "Una tregua no es la paz”, L'Ére Nouvelle, 9 y 24 abril 1937, “Confesiones de un demócrata”, Alcalá Zamora, N. 2000. 36-38

78 Alcalá Zamora, N. 1976. 195-198

${ }^{79}$ Gil Pecharromán. J. 2005. 307 
El mismo día en que se sancionó la Ley de Confesiones y Congregaciones Religiosas, el 2 de junio de 1933, se le recordaba al Presidente de la República las palabras que el diputado Alcalá Zamora pronunció el 10 de octubre de 1931:

"Es evidente, señores, que después de haber proclamado la igualdad de todos los españoles, la indiferencia del credo religioso para la condición jurídica, el derecho de los católicos sufre en el proyecto de Constitución estas limitaciones: una merma evidente del derecho de elegir profesión; una minucia opuesta para esclavizar en determinadas aplicaciones el derecho de reunión; una restricción de la garantía de propiedad, mas o menos afirmada para todos; otra mutilación del derecho de enseñar; una merma del derecho de asociación $\mathrm{y}$, en definitiva, un desconocimiento relativo de la práctica del culto y de la religión"

"Yo en nombre de la libertad, de la democracia y del interés republicano no quiero que esta Constitución surja deformada, ni deforme, porque aspiro a que sea perfecta, igualitaria y cabal para todos los españoles". ${ }^{80}$

Se le acusaba de ofender a los católicos y faltar a su palabra, no esperando a que se crease y pusiese en funcionamiento el Tribunal de Garantías Constitucionales. De ese modo sumaba un abuso más a todos los cometidos por un Gobierno y unas Cortes sin control de legalidad. ${ }^{81}$

Desconocía el nuncio los motivos del Presidente de la República. Ese juicio se explica por la reacción emocional ante un hecho, que tenía como contexto las dificultades de la Iglesia en México, Alemania e Italia, y la persecución de los cristianos en la URSS.

La ley que regula el Tribunal de Garantías Constitucionales fue refrendada el 14 de junio de 1933, es decir, doce días más tarde. ${ }^{82}$ Alcalá Zamora comentó lo que sobre él dice la Constitución de la República Española. ${ }^{83}$

Con el gobierno de Manuel Azaña en precario, se discutió la Ley Electoral. No había una normativa para celebrar elecciones. El decreto del mayo de 1931, dado por el Gobierno provisional, se refería a la convocatoria de Cortes constituyentes. Se necesitaba un sistema electoral completo. Debía hacerse en las Cortes. Eso significaba confrontación entre los criterios de los partidos. Todos los modelos posibles tienen efectos, inevitables, que pueden asustar, porque pueden lesionar la equidad y la justicia. Una ley electoral es siempre un mal menor. Lo había dicho un diputado y Azaña lo recogía en su intervención del 6 de julio de 1933.

Entre los dos sistemas, el proporcional y el mayoritario, Azaña votaría siempre por el segundo. Era el que recogía el proyecto. No quería entrar en asuntos teóricos, sino en el examen de la oportunidad de uno u otro sistema.

En polémica con Ángel Ossorio, y apelando a la conveniencia, recordó Azaña que todas las leyes electorales vigentes en España habían elegido el sistema mayoritario. No era una novedad. El peligro era el aplastamiento de las minorías, el copo de las mayorías.

80 "Una opinión de máxima autoridad", $A B C 2$ junio 1933, 17

${ }^{81} 6199$ Tedeschini-Pacelli, 4 junio 1933, ASV Arch.Nunz.Madrid 930 (1) 41.

${ }^{82}$ Gaceta de Madrid 181 (30 junio 1933) 2331-2341

83 "Los defectos de la Constitución de 1931 y Tres años de experiencia constitucional”, Alcalá Zamora, N. 2002. 223-231. Su propuesta de reforma, del 8 septiembre 1935, Ibídem. 50-54. Lo trató antes, en enero de 1935, "Tres años de experiencia constitucional", Alcalá Zamora, N. 2002. 294-298. 
"No copa el que quiere sino el que puede. Pero el que puede copa". Era su filosofía y su estilo. Bastaba un ejemplo. Lo puso Juan Botella Asensi. En un cálculo sobre los 300000 electores de Madrid. En la primera vuelta con 100000 sufragios obtienen 14 diputados de 18. Las minorías, que no han alcanzado el $30 \%$, se quedan sin representación. En el ejemplo de Asensi eran los otros 200000 electores. Se preguntaba si no era una burla dejar sin representación a los 200000 electores que habían votado a grupos dispersos. Eso no podía justificarse como "republicano", pues, al país, consultado con este sistema, se le decía que a las Cortes iba la representación de la Nación. ${ }^{84}$

No lo consideraba así Azaña. Una vez más, defendía sin fisuras su posición. Replicó al ejemplo matemático de Asensi: "nada es tan peligroso, elástico ni engañador como la Aritmética". El sistema mayoritario no era el único que aplastaba a las minorías y el Gobierno había pensado de qué modo pudiera evitarse el copo.

Quería Azaña que se pensara en otro peligro. Ponía un ejemplo: el que los republicanos fueran divididos a la elecciones y no hubiera una segunda vuelta. Se produciría un caso de aplastamiento invertido: la minoría sobre la mayoría. Daba por supuesto Azaña que los republicanos eran mayoría. Quizás temía la unión de las derechas, no republicanas. Justo lo que sucederá en la primera aplicación de su Ley Electoral.

Azaña creía que el modelo elegido obligaba a los partidos republicanos a ser disciplinados. Les venía bien aprenderlo, aun a costa de la derrota. Por eso estaba prevista una segunda vuelta. Concluyó su discurso con una declaración de modestia respecto a la misión de su Gobierno. Sin embargo, y dicho en plural, confiesa:

“tenemos el decoro de nuestro deber, la convicción del servicio a que nos obliga nuestro destino y el suficiente patriotismo y el suficiente republicanismo y sentido cívico de nuestra obligación para saber que nuestro papel es pasajero, transitorio y sujeto a discusión y quizás a derrota. Y para mí, no habrá placer más grande que confundirme un día entre la masa de ciudadanos y hacer cola a la puerta de un colegio electoral para ver el ensayo de esta ley que votan las Cortes". ${ }^{85}$

Al pronunciarse por un sistema mayoritario, como el elegido y para entender sus razones, conviene recordar las palabras de Azaña para justificar la Ley de Defensa de la República. Cuando el Gobierno la aplica sabe que usa un poder extraordinario, "pero un poder que está incorporado a la Constitución, provisionalmente, y que lo ejercita dentro de los términos y de los limites que la ley misma le ha señalad”. Es una ley a extinguir, pero mientras exista, el Gobierno la aplicará. La extinción estaba en manos de las Cortes.

La extrañeza de algunos diputados se debe a que, en España, ha habido una pobre experiencia parlamentaria y unos Gobierno débiles, antes de la llegada de la República. Ahora el Gobierno asume sus funciones, tiene las riendas para controlar el orden público.

De eso se concluye: quien lo preside es "un déspota". No es verdad. Estaba actuando con una estricta defensa del concepto político de la libertad y una represión "tan mesurada como es menester,

\footnotetext{
${ }^{84}$ Noticia en Simeón Vidarte, J. 1977: 624.

${ }^{85}$ Manuel Azaña, DS/CC 366 (6 julio 1933) 13904-13914 y 1934. En el poder y en la oposición (19321934), tomo segundo, Bilbao, Madrid, Barcelona, 113-131.
} 
responsable siempre y atenida a lo necesario, cada vez que alguien o algo infringe las garantías de la libertad de la mayoría de la nación".

No hay una mayoría dócil que apoye al Gobierno. Este es el resultado de una mayoría, cuya voluntad y mente interpreta el Gobierno. ${ }^{86}$

Volvamos al sistema electoral aprobado. A él se opuso Alcalá Zamora. Tuvo graves e inmediatas consecuencias. Viendo el desgaste de las Cortes Constituyentes, disolvió la Cámara. La prueba de que acertó fue el gran giro político que supuso la votación. Al recordarlo, lamentó que no se acogiera su idea de modificar la ley electoral para evitar los bandazos políticos. No dejaba la oportunidad a la existencia de partidos entre la derecha y la izquierda.

De ese modo veía que la situación creada tras las elecciones funcionaría como "acelerado prólogo parlamentario de la guerra civil". Los 42 diputados que la izquierda echó de la Cámara bajo los gobiernos de Azaña se convirtieron en 212 en diciembre de 1933. Lamentó Alcalá Zamora que durante el segundo bienio no se hiciera esa modificación electoral y se fuera aplazando una reforma transaccional de la Constitución.

Por eso se llegó a la situación dramática abierta en febrero de 1936 y que condujo a los que Alcalá Zamora considera el final de la República "constitucional, democrática, de derecho". La fecha fue el 7 de abril de 1936, un golpe de estado parlamentario culminó en una elección de Presidente de la República, sin garantías en la votación de los compromisarios. Se volvía a lo que, juzgando la Restauración, llamó "parodia del voto, envilecida y muerta", culminada en la Dictadura de 1923.

El horizonte abierto aquellas jornadas del 12 al 14 de abril se cerraba. En aquella ocasión, incluso con la monarquía y la dinastía, hubo rectitud, pasión por la justicia, veracidad, en quienes fueron sus jueces, fiscales y testigos de cargo. Por eso, por haber actuado obedeciendo el imperativo de la conciencia y de la dignidad, el pueblo pudo aceptar un fallo benevolente. ${ }^{87}$ Vino luego, el aniquilamiento del adversario, sin cuartel, sin tregua, sin piedad.

Otro factor político empujó en esta dirección. Hombre liberal, Alcalá Zamora consideraba que los excesos del PSOE tenían como atenuante la presión a la que lo sometió la "carrera hacia soluciones demagógicas emprendida por los radicales socialistas". Aquí no sirvieron estos para favorecer la tendencia evolutiva del PSOE, como los otros partidos afines de fuera hicieron con los socialistas. Querían conquistar a las masas, aun siendo un partido pequeño burgués. Eso explica lo que Alcalá Zamora llamó su "campeonato de extremismo". El resultado para los radical-socialistas fue un estrepitoso fracaso.

En 1938 volvió sobre el papel de los radical-socialistas, en el centenario de la Constitución del 18 de junio de 1837. Esta ni contradecía ni dañaba la realidad histórica. Mantuvo todo lo que había de legítimo o de provechoso en ella. Respetó los valores morales. Recibió influencia del modelo belga, donde se conciliaba amor a las libertades y catolicismo

\footnotetext{
86 "La periódicos y la Ley de Defensa de la República”, DS/CC 132 (9 marzo 1932) 4365-4371 y 1932 Una politica (1930-1931), Bilbao, Madrid, Barcelona, Espasa Calpe, 313, 318, 320, 323.

87 "Régimen político de convivencia en España", 1945, Alcalá Zamora, N. 2000. 70, 83 y 95. Apareció en Buenos Aires, Editorial Claridad, 1945. En esta edición 67-233.
} 
"Cuando en 1931 queríamos unos pocos hombres, de previsión y buena voluntad, que la Constitución abarcara con la mayor y más fácil amplitud de todas las repúblicas a todos los españoles, se nos impuso, por abandono de las derechas y fanatismo de las izquierdas, otra Constitución más de partido, de secta".

Fue la Constitución del partido radical-socialista, que tenía un año de historia y que se hundió en las elecciones siguientes. Se impuso y "no se recató por ellos y sus aliados, que hacían la Constitución minuciosa y sectaria, para aprovechar una mayoría pasajera y ficticia, imponiendo su criterio en todo a futuras y efectivas mayorías.

Y esa Constitución se procuró que fuese irreformable, aun en sus dislates más evidentes... eso sí, para violarla el todos sus preceptos, al gobernar solo sus autores y defensores. El trágala eclipsado en 1837, reapareció, una vez más, forjando un arma y creando un ambiente de guerra civil, para llegar a ésta, cuyo himno se había cantado con inaudita demencia en las últimas Constituyentes". 88

\section{"CON NADIE ME SIENTO INCOMPATIBLE"}

Coherentes con su idea de la política y con su opción, antes de que se conociera el resultado de la segunda vuelta del 3 de diciembre de 1933, los derrotados pidieron a Alcalá Zamora que anulase las elecciones. Entre los que esto deseaban, estaba Félix Gordon Ordás, ministro de Industria. Se quedó de momento solo. Azaña, Casares y Marcelino Domingo escribieron a Martínez Barrio. Alcalá Zamora se negó a leer la carta. Pedían lo mismo que Gordon Ordás. Los dos presidentes, el de la República y el del Gobierno, lo rechazaron. ${ }^{89}$

En la imposición de condecoraciones a las autoridades por su actuación en los sucesos revolucionarios de diciembre de 1933, pronunció Alcalá Zamora el 7 de febrero un discurso.

La República se apoya y organiza en una fuerza imparcial, que depende sólo del poder público, extraña a la violencia y a los odios de partido. Es inconciliable con la idea que sitúa el monopolio de la fuerza en una tendencia contra otra, en una clase contra otra, en un partido contra otro. La fuerza depende exclusivamente del Poder público. Si no fuera así, sería opuesta a la esencia de la República y a la Constitución. Y en ese caso, haría falta "otro presidente".

Esta fuerza pública, en una sociedad tan compleja, necesita la asistencia ciudadana. Por eso es una fuerza que no intimida la libertad ciudadana y su "marcha alegre" significa "el amparo del derecho de cualquiera y la protección de la paz de todos"

Su ambición fue "un Estado de Derecho, un régimen tan justo, tan flexible y tan sensible, que sea innecesaria la revolución legítima, la de la voluntad nacional, y a la vez tan fuerte, que haga ineficaz, que haga impotente la revolución facciosa, la revolución del capricho, del interés, de la parcialidad.

\footnotetext{
${ }^{88}$ Centenario obscurecido", La Nación, 24 marzo 1938, "Artículos publicados en el diario "La Nación” (Buenos Aires, 1936-1939), Alcalá Zamora, N. 2003. “153-155.

${ }^{89}$ Alcalá Zamora, N. 1976254 y 259-260.
} 
Unas semanas más tarde, el 23 de septiembre, en Valladolid, tuvo una intervención sonada. Fue pocas fechas antes, casi víspera, de la revolución de octubre.

Llamó a pensar en España, a dominar por ella el exceso de pasión y a "sentir el imperio del deber". Una democracia revela que un pueblo es lo que quiere ser, lo que merece ser.

Todo lo comprendía también la impaciencia de algunos y esa reserva de "pasiones negativas", que no salieron porque la revolución de abril de 1931 vino en paz.

"Con nadie me siento incompatible con nadie estoy ligado". Deseaba vivir alejado de toda significación política. A nadie cerraba la puerta y de nadie recelaba. Respetaba todo lo que había de noble en la tradición y lo que hay de atrevido, de igualitario, de expansivo, de fraterno, de generoso, en quienes sueñan una transformación social. Le ayudaba en esa conducta su sobriedad y la sencillez de su familia. ${ }^{90}$

Quienes lo eligieron, sabían que sería un presidente constitucional, no un Mesías. No lo necesitaba España. Los mesías raramente salvan a un pueblo, más bien "con frecuencia sucede lo contrario". Además su propia personalidad y el juramento hecho lo incapacitan para ese papel. Declaraba que "para lo excepcional, para lo milagroso, para lo personal, no sirvo yo y [eso] se sabía al elegirme".

Entendía, y no necesitaba que se lo recordaran, que existían, diferencias, sutiles, entre España, la Constitución y la República. Y concluía: “....sé y proclamo que España no tiene más salvación que dentro de la República, y la República, dentro del Derecho, del respeto escrupuloso a todas las normas, empezando por las constitucionales".

La revolución española fue pacífica y ordenada. Era su timbre de honor. Pero dejó "sin explotar el residuo acumulado de las pasiones negativas" que hallan escape en las revoluciones violentas y producen "terribles y compensadoras explosiones de los extremos". España estaba exenta, relevada, porque había conocido eso durante un siglo.

La pacífica posición de España, con sus vecinos y en la vida internacional, parecía avalar la creencia de que los españoles estaban libres de la pasión interna, de la obligación de usar la prudencia, del llamamiento a realidades que en otros países recuerdan invasiones, guerras. Si alguna vez España no pudieran mantenerse ajena a una guerra, segura en su neutralidad, necesitará "cohesión nacional, sentimiento de patria e interés supremo de patria" que compensen, a fuerza de guerra, de millones de muertos, lo que otros países han adquirido "con la idea clara de un interés nacional superior a todas las luchas de los hombres".

Nadie tiene que renunciar a lo suyos, porque el patriotismo es una coincidencia pujante de diversos intereses. Solo se pide a cada uno, a todos, que luche por el interés general, que cumpla con su deber. A eso convocaba a los españoles, pues era "el mayor deber suyo". 91

${ }^{90}$ Imposición de condecoraciones a las autoridades por su actuación en los sucesos revolucionarios de diciembre de 1933", Madrid 7 febrero 1934 e "Inauguración del Congreso de Riegos", Valladolid 23 septiembre 1934, Alcalá Zamora, N. 1979. 629 y 631-633 y 642-645.

91 Inauguración del Congreso de Riegos", Valladolid 23 septiembre 1934, Alcalá Zamora, N. 1979. $642-645$ 
La Constitución de 1931 fue para Alcalá Zamora "la más defectuosa y menos viable de sus coetáneas en el mundo y de sus antecesoras en España, a causa sobre todo de la Cámara única, con todos los daños mortales y de su extravíos y bandazos alternados".

A eso se sumaba un "funesto sistema electoral, que amparaba la grave injusticia de que un escaso número de votos, por varios procedimientos y sin llegar a la mayoría absoluta de los votantes, el grupo más favorecido se llevara de cuatro actas, de siete, cinco, de trece, diez, de dieciocho, catorce. A eso se sumaba la cómoda aceptación con que los grupos intermedios aceptaban las actas de regalo. Esa fue una de las calves de la impotencia de estos diputados cuando quisieron frenar la catástrofe en 1936.

La oposición o la mera resistencia a modificar estos dos aspectos del sistema lo vincula años más tarde Alcalá Zamora con la anulación de las actas de Melquíades Álvarez y de José Martínez de Velasco en 1936. Ambos fueron asesinados en la Cárcel Modelo el 22 y 23 de agosto. ${ }^{92}$

La vida constitucional de la República puso de manifiesto los defectos de la Constitución. Fue Alcalá Zamora anotando los artículos que deberían reformarse. Hizo un esquema y expuso su propuesta de reforma en el Consejo de Ministros los días 3, 4 y 5 de enero 1935. Presidía el Gobierno Alejandro Lerroux. Se acercaba la fecha en que esto pudiera plantearse legalmente. El mayor obstáculo era el artículo. 125. El texto fue escrito antes de los sucesos revolucionarios octubre de 1934 y antes de la crisis constitucional que supuso su destitución el 7 de abril de 1936.

La izquierda quiso que la Constitución fuera irreformable. La derecha, consolidada su alianza con los radicales, les dejó las ventajas de usar en poder. La CEDA y la otra derecha hostil a la República pensaban tener mayoría suficiente en 1937. Por eso quiso retrasarla hasta esa fecha. A la vista de esa actitud, decidió Alcalá Zamora presentar su propuesta al Gobierno. ${ }^{93}$

Esta era su propuesta. En el preámbulo, subrayó que, por primera vez en la historia de España una reforma constitucional iba a realizarse según lo previsto en la misma Constitución. Era coherente con el momento inicial de la República: se pasó de una monarquía, caída en el absolutismo, a una democracia constitucional por un procedimiento electoral no previsto en la ley, pero sancionado incluso por los que salían perjudicados.

Las constituciones suelen engendrase en trances de agitación, que son pasajeros, por eso la reforma debe hacerse cuando estos han pasado y hay calma, para que así "la ley básica del Estado" se libre de las notas cargadas de pasión extremista".

La Constitución de la República, nacida en el ambiente posterior a la Gran Guerra, tenía una carga teórica. La superposición de concepciones filosóficas produce el riesgo de salirse de la realidad. La reforma debe basarse en la experiencia de tres años y en la de otros países que también han reformado la suya.

Planteaban la revisión incluso los que votaron la Constitución. Era un texto, que respondía a un ambiente y a una decisión política, en pugna con la realidad del país. Debía llevarse a cabo con serenidad y sin prisas, pues era una tarea era ardua y compleja. Habría que prepararla. Para que el texto fuera reflejo de

92 Alcalá Zamora, N. 1977. 335 y 339-340.

93 “Los defectos de la Constitución de 1931 y "Tres años de experiencia constitucional”. Alcalá Zamora, N. 2002. 50-54 
la sociedad había que ir a una revisión profunda, pero sin apasionamiento y sin espíritu de represalia. La experiencia electoral de 1933 podría servir de lección.

Del artículo 26: se mantiene inamovible la separación Iglesia-Estado. Pero en su redacción hay elementos que pueden ser sacados a leyes ordinarias. Y eso impone su reforma. ${ }^{94}$ El nuncio envió un resumen. ${ }^{95}$

Debía revisarse, en primer lugar, el sectarismo antirreligioso. El artículo 26 era una ignominia. ${ }^{96} \mathrm{El}$ objetivo era recuperar la libertad para la Iglesia. Había que fijar asimismo el concepto de la propiedad con los criterios de la doctrina social católica. Era necesario examinar el funcionamiento de la enseñanza, tal como lo había diseñado la Constitución y las leyes posteriores. El parlamento necesitaba el contrapeso de una segunda cámara. Las facultades del poder moderador resultaban excesivas, siendo exiguas las atribuciones del gobierno. La nueva Constitución servirá para responder positivamente a los problemas suscitados por la revolución. ${ }^{97}$ Eran los días inmediatamente posteriores a la de octubre en Asturias.

Las amnistías, prodigadas por las Cortes, no han pacificado. ${ }^{98}$ Han agravado las inquietudes políticas y las amenazas al orden público. En la primavera de 1934 la izquierda se opuso a una amnistía para los implicados en el golpe del 10 de agosto de 1932. Cambiaron de posición en el otoño de 1934. Entre otras restricciones y circunstancias que debe tenerse en cuenta, debe limitarse la intervención del poder judicial. ${ }^{99}$

En septiembre de 1935 reflexionó Alcalá Zamora sobre la aplicación del artículo 26. No estaba prevista la negociación con la Santa Sede, pero tampoco quedó excluida la posibilidad de un convenio y hasta de un Concordato. Cuando se habla de una "ley especial", se refiere a la que apruebe ese acuerdo. Desde el comienzo se supo que, más allá de su actitud ante el artículo 26, la posición de la Santa Sede era negociar. Era evidente que ningún Gobierno habría aceptado como condición previa la reforma de la Constitución. ${ }^{100}$

${ }^{94}$ Reproducido como anexo en Arxiu Vidal i Barraquer 1986, 908-910.

957186 Tedeschini-Pacelli, 15 enero 1935, ASV Arch.Nunz.Madrid 917 (4) 659-671. El resumen mecanografiado, ib. 641-658. ¿Se había excedido de sus funciones como presidente de la República? 12 febrero, Ibídem 682. El 19 de febrero el director de El Debate, Francisco de Luis, entregó a Tedeschini el documento sobre el que se iba a trabajar, ib. 685 y 688-694. "Ante la reforma constitucional", El Debate 20 marzo, 1. La oposición al proyecto, J. Díaz Fernández, "Sobre la revisión. Cuatro artículos esenciales", El Liberal, 29 marzo 1935,8 .

${ }^{96}$ No sería fácil que se atendiera esa demanda. "Para Guerra del Río sólo hay un artículo intangible en la Constitución: el 26. Del mismo señor son otras manifestaciones, tan de su cosecha masónica, como la anterior", La Gaceta del Norte 10 de enero de 1935, 3. Mientras se debatía en sesiones especiales de las Cortes todo lo relativo al alijo de armas y los suplicatorios de los diputados implicados en la revolución de octubre, los radicales que pertenecían a la masonería, pedían la ruptura del Gobierno con la CEDA. "Últimas noticias de todas partes", La Gaceta del Norte 17 de febrero, 9.

97 "La revisión constitucional. Debemos apuntar alto y unidos", La Gaceta del Norte 6 de enero, 1. Censurado parte del texto.

${ }^{98}$ Las amnistías sólo podrán ser acordadas por el Parlamento. No se concederán indultos generales. El Tribunal Supremo otorgará los individuales a propuesta del sentenciador, del fiscal de la Junta de Prisiones o a petición de parte.

En los delitos de extrema gravedad, podrá indultar el Presidente de la República, previo informe del Tribunal Supremo y a propuesta del Gobierno responsable" (artículo 102).

99 "Tres años de experiencia constitucional”, Alcalá Zamora, N. 2002. 288.

${ }^{100}$ No era una ensoñación de Alcalá Zamora esta previsión. Desde junio de 1929 estaba negociando con la República de México. Pietro Gasparri, Secretario de Estado, solo pedía una aplicación conciliadora de las 
El párrafo cuarto de este artículo molestó al Papa. ${ }^{101}$ Se le agraviaba haciendo de la especial vinculación de la Compañía de Jesús con él una circunstancia desfavorable. La Santa Sede debe aspirar a que se modifique, pero no puede hacer de ese deseo una exigencia, antes de concertar acuerdo alguno con España. Un Concordato no excluye una legislación unilateral. Ha sido esta "cuestión religiosa" una larga historia entre la Santa Sede y España en relación con la tolerancia religiosa y el estatuto de las órdenes y congregaciones religiosas.

Con el cambio de mayoría parlamentaria se inició la negociación. Casi todas las órdenes religiosas conservaban sus casas. $\mathrm{Y}$ el influjo de los jesuitas estaba intacto.

Si se empeñara la Santa Sede en la enmienda del texto, desencadenaría una campaña en contra. Se acusaría a la Iglesia de injerencia en los asuntos del Estado y a este de abdicar de su soberanía. El Gobierno que lo aceptase debilitaría su posición interna. En cuanto consiguiera su objetivo, la Iglesia perdería en la negociación una posición que le beneficia: ser la parte agraviada que pide reparación.

Leandro Pita Romero lamentó la estrategia de la Santa Sede durante esos meses de negociación. Se había equivocado. ${ }^{102}$

El apasionamiento y la convicción de la que la hegemonía de la izquierda en las Cortes iba ser perpetua motivaron que, para la disolución de las Cortes, el procedimiento fuera muy limitado y muy rígido. Esa atribución del Jefe del Estado no debe prodigarse, pero no deba quedar atada, porque eso limita la soberanía del país, al que se le obliga a estar limitado en su soberanía, si tiene que aguantar un Gobierno ya sin el apoyo de la opinión.

Este hecho va ligado a las causas de destitución del presidente, a la elección del sucesor por diputados y compromisarios y revela una vez más el error de un sistema unicameral, con ausencia del Senado. Este, dentro de las relaciones Presidente-Gobierno reduciría el necesario poder de veto que aquel tiene en el refrendo las leyes. ${ }^{103}$

La misión de la Presidencia de la República era necesaria como contrapeso y garantía frente al modelo de un poder legislativo, "de cámara única, omnipotente, formada por partidos sectarios". Ese

leyes, que deberían reformarse cuando cambiara la opinión y esa decisión no provocara males mayores. Una extensa documentación que va desde 1929 hasta 1937 se encuentra en ASV Arch.Deleg.Messico cajas 72-75. La situación en España no era tan grave jurídicamente. Ni iba precedida de tres años de lucha armada en defensa de la libertad religiosa, la guerra de los Cristeros.

${ }^{101}$ “'Quedan disueltas aquellas Órdenes religiosas que estatutariamente impongan, además de los tres votos canónicos, otro especial de obediencia a autoridad distinta de la legítima del Estado. Sus bienes serán nacionalizados y afectados a fines benéficos y docentes."

102 "Ante los anuncios de convocatoria electoral, que alejan el horizonte de la reforma constitucional, en cuya espera demoró la Santa Sede el final de las negociaciones, no dejé de advertir cómo, después de lo actuado hasta aquí y de las ofertas hechas por la buena voluntad de los gobiernos, toda responsabilidad por el giro que tomasen las cosas en el futuro habría de recaer íntegramente sobre la Santa Sede, si se equivocase en su plan de ir a un concordato amplio y entretener el ínterin, beneficiando a una situación de hecho como la actual". Leandro Pita Romero-Alcalá Zamora, Roma 2 enero 1936, en Niceto Alcalá Zamora 8 abril 1936 y epílogo, Alcalá Zamora, N. 2011. Asalto a la República. Enero-abril 1936, Madrid: La Esfera de los Libros: 426-427

${ }^{103}$ Tres años de experiencia constitucional”, Alcalá Zamora, N. 2002. “259-264 y 275-285. 
apasionamiento agresivo lo paró Alcalá Zamora. Por eso no se dieron cuenta de esa situación incendiaria, mientras se mantuvo en el cargo.

Quienes lo destituyeron cometieron doble injusticia: unas veces los dos bandos creyeron que había sido un dique para sus planes. Otras, pensaron que les había dado insuficiente apoyo. Eran dos fanatismos contrapuestos y contagiosos con igual demencia. No pudieron percibir ni valorar esa tolerancia justa, amparando a las víctimas de la inquisición roja y a las de la inquisición negra o blanca

La disolución de las Cortes estaba muy restringida en la Constitución. Quisieron que se ejerciera esa atribución a gusto de cada bando.

En cuanto al modelo de sociedad, para unos Alcalá Zamora era un protector del fascismo. Para los otros, el cómplice de la revolución proletaria.

Frente a las injurias, porque dentro de España las censuras las toleran cuando no las espolean, quería permanecer sereno, "sin alterarme, sin enojo, casi con gratitud, les llamo los faros de mi conciencia y los puntales de mi conducta". ${ }^{104}$

Examinó igualmente el problema regional. ${ }^{105}$

\section{UNA TREGUA NO ES LA PAZ}

Su obra, Los defectos de la Constitución de 1931, con lo que expuso ante el consejo de ministros, fue a la imprenta cuando dejó de ser presidente. Había meditado este asunto desde 1932. Quiso ser una advertencia y una condena de la guerra civil, "el peligro terrible y la herida incurable que yo deseaba curar". 106

"La campaña electoral fue toda ella demagógica, pero mucho más violenta la derechista y más cautelosa la de la izquierda". ${ }^{107}$

En la primera vuelta el Frente Popular obtuvo, pese a la participación de los sindicalistas, poco más de 200 escaños de los 470 que tenían las Cortes. Era la minoría victoriosa, pero lejos de la mayoría absoluta.

Antes de que las Juntas provinciales del censo dieran los resultados el 20 de febrero, el Frente Popular se declaró vencedor y tomó el poder. Algunos gobernadores dimitieron. Lo hizo Portela Valladares, presidente del Gobierno. Hubo violencia en las calles y los seguidores del Frente Popular se apoderaron de las actas electorales. Los resultados pudieron ser falsificados.

104 “Faros y Puntales" La Nación, 28 diciembre 1938, “Artículos publicados en el diario "La Nación” (Buenos Aires, 1936-1939), Alcalá Zamora, N. 2003. 195-197.

105 El análisis de este asunto, artículos Ibídem 12, 14-15 y 19-20, y "Tres años de experiencia constitucional”, Alcalá Zamora, N. 2002. 253-258.

106 . "Capacidad Internacional y Guerra civil” y "Una tregua no es la paz”, L'Ére Nouvelle, 9 y 24 abril 1937, “Confesiones de un demócrata”, Alcalá Zamora, N. 2002 36-38.

${ }^{107}$ Alcalá Zamora, N. 1976. 346. 
"Las mayores y más patentes audacias las llevó a cabo la comisión de actas del Congreso, del todo en manos de la nueva mayoría, que ya había incorporado a los vascos, en la singular alianza que solidarizó a estos de tan distinto programa con todos los núcleos de aquella”.

El 17 de marzo se constituyó ó la Comisión de Actas. La presidió Indalecio Prieto. La derecha se retiró ante la falta de imparcialidad. Manifestaron que dejaban en manos de la izquierda "la suerte del sistema parlamentario." Prieto, su presidente, dimitió “asqueado de los abusos". Había dicho en otros tiempos a Alcalá Zamora que la discusión de las actas era solo una cuestión de partido, en la que nada tiene que ver ni la justicia ni la conciencia de quien vota en ella.

Las izquierdas, según una caricatura aparecida el 31 de marzo en La Gaceta del Norte, darían "dos 'patás"' a la urna, donde se refugiaban las "esencias liberales" y "el sufragio y la democracia". Su estrategia era utilizar, pero no servir a la República. ${ }^{108}$

La noticia circuló por Madrid el 31 de marzo. Para Alcalá Zamora eso significaba que estaba seguro de su derrota dentro del PSOE y que la alianza de los socialistas con la izquierda republicana iba a menos. Curiosamente, el grupo de Francisco Largo Caballero ponía "sordina" a loa ataques de Prieto, argumentando que un cambio en la Presidencia de la República era un grave riesgo. Era una maniobra. Llegada la decisión de destituir al Presidente de la República toda la izquierda votaría unida. Ese acto "quebrantaría enormemente la ya agrietada organización política de la República burguesa". 109

La derecha española debía examinar si sufría los tres defectos que le había imputado un escritor católico: el miedo, el egoísmo y la intransigencia. Había que vencer el temor, superar la intransigencia y unirse para actuar dentro de la ley y resistir a la revolución. No por motivos bastardos de interés frente a las reclamaciones de la justicia, sino porque, como dijo Jean Jaurès, la revolución pertenecía a una fase inferior y semi-bestial de la evolución humana. No habría que caer en el pesimismo derrotista.

Era posible "salvar los elementos de justicia y de verdad, los restos de patrimonio humano, las reservas divinas que subsisten sobre la tierra y... preparar el orden nuevo que reemplace al presente desorden", había escrito Jacques Maritain. No había que negar los problemas, sino solucionarlos. Esa era la tarea pendiente. ${ }^{110}$

Basta recordar que Alcalá Zamora intervino para advertir que, si repudiaban las actas de José María Gil Robles y José Calvo Sotelo, se deja a la oposición fuera, y eso era suprimir el parlamento.

Algunas anulaciones perjudicaron al partido de Martínez Barrio, Unión Republicana, el menos extremista del Frente Popular. Él fue el candidato más votado en Madrid, junto con Julián Besteiro, que le sacó 203. Fue elegido presidente de las Cortes.

${ }^{108}$ El 15 de abril, José Díaz pronunció en las Cortes una amenaza, que anunciaba el atentado personal contra Gil Robles. El debate lo inició Rodolfo Llopis. DS/C 17 (miércoles 17 abril 1936) 305-323. Las palabras de José Díaz Ramos, 308-314. Así no podía seguir España. El gobierno estaba obligado a defender a sus ciudadanos. Había que dar, con la ley y el derecho en la mano, la batalla a la revolución. "Síntomas de anarquía", La Gaceta del Norte 17 de abril, 1.

${ }^{109}$ Alcalá Zamora, N. 2011. 31 marzo 1936: 357-358

${ }^{110}$ Había que volver la mirada a la clase media, que puso sus esperanzas en la República de 1931. Y marchar hacia el proletariado, teniendo en la memoria las palabras de Bossuet: "Regocijaos: Jesús es de los vuestros". "Resistir y avanzar", La Gaceta del Norte 1 de abril, 1. 
Cuando se le dejó ante la alternativa de asociarse a las violencias o padecerlas, optó por ser "coautor en vez de víctima y es probable que hubiese hecho lo mismo, sin la precaución que tomaron sus aliados". 111

Manuel Azaña y Diego Martínez Barrio manifestaron a Alcalá Zamora que la conducta del Gobierno fue una huida. Hubo un contagio de pánico. Diego Martínez Barrio subrayó que Manuel Azaña será una garantía porque se rodearía de los elementos moderados del Frente Popular. Manuel Azaña dijo a Alcalá Zamora que solo entrarían ministros de su grupo y del de Diego Martínez Barrio.

El gobierno de Manuel Azaña es solo él. Había crisis de hombres políticos. No había donde escoger, por eso Alcalá Zamora se extrañó del aumento de carteras para satisfacer ambiciones personales. $^{112}$

El segundo momento, fue la labor de la Comisión de Actas. Se anularon las de algunas provincias, donde había ganado la oposición. Se proclamaron electos a los candidatos amigos al Frente Popular, que habían sido vencidos. Se echó de las Cortes a algunos diputados de las minorías. ${ }^{113}$

Quisieron convertir las Cortes en una convención, con la hegemonía del grupo menos exaltado y con el aplastamiento de la oposición. En cuanto no fuera necesaria la presencia de la izquierda republicana, pero no obrera, la eliminarían.

Esta previsión de Alcalá Zamora se cumplió casi milimétricamente. Y casi de inmediato. Por eso enseguida se procedió a destituirlo como presidente de la República ${ }^{114}$.

A la vista del sistema electoral, es evidente que la izquierda consiguió la mayoría en las elecciones de 1936, pero su mayoría aplastante final fue el resultado de "los excesos más violentos e ilegítimos: la falsedad de los escrutinios con la ayuda del desorden público; la proclamación arbitraria en la Cámara de candidatos derrotados, siguiendo el mismo capricho con el que despedían a los diputados elegidos, la anulación masiva de los mandatos, las nuevas elecciones dirigidas por la violencia..."

Estallada la guerra, la Cámara quedó reducida, porque muchos diputados se exiliaron o huyeron. Nunca se presentaron en las Cortes más de 185 diputados de los 473 que las integraban. ${ }^{115}$

Firmó Alcalá Zamora el decreto de suspensión de las Garantías Constitucionales. ¿Cómo se usó? Se dejó en manos de los perturbadores, que marcaban a las autoridades su aplicación. Denunció Alcalá

${ }^{111}$ Alcalá Zamora, N. 1977. 350-352.

${ }^{112}$ Alcalá Zamora, N. 2011. 188 y 192.

${ }^{113}$ Estos datos muy conocidos, usados para sostener que el Gobierno formado por Manuel Azaña no era legítimo, los ha incluido Pío Moa en su reseña de los diarios de Alcalá Zamora en 1936. Alcalá Zamora, N. 2011, Asalto a la República. Enero-abril 1936, Madrid: La Esfera de los Libros: 520 pp.

114 "Les débuts du Front Populaire", Journal de Genève, 17 janvier 1937, 1, reproducido en 2009. Causa General. Ministerio de Justicia 1943. la Dominación Roja. Avance de la Información instruida por el Ministerio Público en 1943, Astorga, León, Editorial Akrón. 49-51.

115 "Facilidades negativas para la paz en España", L'Ére Nouvelle, 21 octubre 1937, "Confesiones de un demócrata”, Alcalá Zamora, N. 200076. 
Zamora la ventaja que El Liberal, de Indalecio Prieto, obtuvo. Fue el único periódico no sometido a ella. La situación la calificó Alcalá Zamora como "tolerancia de la anarquía". ${ }^{116}$

El 15 de marzo de 1936, llamaron a Niceto Alcalá Zamora desde cerca de Jaén. Le comunicaban que su familia materna acababa de ser encarcelada. Recurrió al Gobierno. La muchedumbre exigió el encarcelamiento de sus sobrinos y de otras "personas muy respetables" Los condujo a la ciudad la fuerza pública. Pasaron por tres ciudades importantes. Así se hacía propaganda anarquista: se mostraba que los enemigos serían castigados. El 16 fueron liberados. Pero el Gobernador Civil les aconsejó que se marcharan, "un exilio voluntario", porque no podía asegurar sus derechos, "incluido el derecho a la vida". ${ }^{117}$

La crisis del 7 abril 1936 tiene su origen en la disolución de octubre de 1933 y en la de diciembre de 1935. Una y otra fueron precedidas por presiones de quienes creían que con esa medida quitaban la mayoría a sus enemigos políticos. ${ }^{118}$ Mucho más cerca de su destitución fue el Consejo de Ministros del 2 de abril. En él Alcalá Zamora acusó al Gobierno de las irregularidades cometidas en las elecciones del 16 de febrero. Pidió que se cancelasen las elecciones municipales. El clima reveló la incompatibilidad entre el Gobierno y el Presidente de la República. ${ }^{119}$

\section{"EL ASALTO A LA REPÚBLICA"}

La omnipotencia del parlamente no debe identificarse con la idea de la soberanía nacional. Este dato es importante para entender el problema que plantea su disolución. El parlamento, tras perder el contacto con la opinión, se olvida que el representante es menor que el representado. Cuando se restringe la disolución, esa medida no es un favor a los partidos, sino a sus oligarquías. Cuando la Cámara tiene el apoyo del país, no hay riesgo de disolución. Según el artículo $57,{ }^{120}$ la potestad de revisar las actas puede hacer que un Congreso mal elegido sea el que más se oponga a la disolución. Porque cree que de ese modo no corre el riesgo de que su viciado origen no quede ratificado. ${ }^{121}$

El 20 de octubre de 1935 habló Azaña en el "Campo de Comillas" (Madrid). La situación se había deteriorado. La conjunción Partido Radical-CEDA puso a prueba la capacidad de Alcalá Zamora para prestar a las minorías "la representación de ese término medio que constituye la expresión liberal de un pueblo democrático". Se reproducía una situación similar a la de tiempos de Alfonso XIII. ${ }^{122}$

El cardenal Vidal i Barraquer se entrevistó el 18 de noviembre con el Presidente de la República, que le comentó la situación política. Estaba el Partido Radical muy quebrantado. Lo mantenía unido

116 Alcalá Zamora, N. 1976. 352-353 y 258.

117 Por qué no presenté la dimisión”, L’Ére Nouvelle, 12 enero 1937, “Confesiones de un demócrata",Alcalá Zamora, N. 2000. 15.

118 "Los defectos de la Constitución de 1931 y Tres años de experiencia constitucional", Alcalá Zamora, N. 2002. 186-188.

${ }^{119}$ Un comentario, Alcalá Galve, A. 2006. 636-686, sobre todo 642-643 y 671 y 675.

120 "El Congreso de los Diputados tendrá facultad para resolver sobre la validez de la elección y la capacidad de sus miembros electos y para adoptar su Reglamento de régimen interior".

${ }^{121}$ Los defectos de la Constitución de 1931 y Tres años de experiencia constitucional”, Alcalá Zamora, N. 2002. 179-188.

${ }^{122}$ Rivas Cherif, C. de. 1981. 311. El libro fue escrito entre 1941-1943, mientras el autor estaba en la cárcel. La primera edición en esta editorial es de 1979.

Hispania Sacra, LXIV, Extra I, enero-junio 2012, 69-148, e-ISSN: 1988-4265, doi: 10.3989/hs.2012.027 
Alejandro Lerroux. Quería aguantar la situación hasta que se aprobara la reforma de la Constitución y, por imperativo legal, tuvieran que disolverse las Cortes, ahorrando así a la Presidencia de la República tener que tomar esa decisión, reservándose así la segunda y última posibilidad de hacerlo en su mandato.

Había que ser cautos. Si la reforma era amplia, las izquierdas no la votarán ni muchos radicales. Poco podía esperarse del derrotismo de la extrema derecha. La reforma no saldría sin mayoría absoluta.

A esas alturas, Vidal i Barraquer estaba seguro de que socialistas, comunistas y anarquistas iban a la revolución social y política. Eran un frente unido contra la religión y el orden. Si apoyaban a las izquierdas que creían en la legalidad era para que estas les abrieran paso. Eso fue lo sucedido en octubre de 1934. Hubo allí un proyecto político, no reivindicaciones obreras, pues los trabajadores asturianos tenían las mejores condiciones salariales de España.

Creía Alcalá Zamora que el modus vivendi hubiera ayudado a pacificar los espíritus, marcando las líneas del futuro concordato y hasta de la reforma constitucional. Habían sido las extremas derechas las que habían creado en la Santa Sede la certeza de que vencerían las derechas y que la reforma de la Constitución era asunto fácil. Bastaba con que en el Vaticano hubieran aceptados aprobar las medidas unilaterales que beneficiaban a la Iglesia, dando fuerza de pacto a lo que eran actos del Gobierno.

Se llegaba tarde. Las Cortes tenían poca vida por delante y no les daría tiempo a aprobar un posible acuerdo. Vidal i Barraquer no tuvo otro argumento que insistir en la prudencia y buena voluntad de Roma y en la ventaja de mantener el embajador para que presentara las demandas del Gobierno.

Tuvo una entrevista con José Martínez de Velasco, ministro de Estado. Había dicho al nuncio y al embajador que no sería fácil hallar otro ministro en mejor disposición que él. La reforma de la Constitución estaba casi varada. Algunos ministros estaban a favor de que se modificara el artículo 125. Vinieran luego Cortes Constituyentes y fuera estas las que la hicieran. Creía que había tiempo para que el Gobierno consiguiera la aprobación del presupuesto y del acuerdo. Todas las puertas quedaban abiertas: reforma de las leyes en el modus vivendi, regateo, como en cualquier negociación, pero sin exigir mucho por parte del Gobierno.

Siendo una situación difícil, Vidal i Barraquer informaba que diversas personas, consultadas por él, creían que, con prudencia, podría superarse. Si los revolucionarios se echaran a la calle volverían a ser vencidos, pero también hay que vencerlos en las urnas. Eso debía marcar una campaña electoral sin notas estridentes y con mucha moderación, de modo que no se agrande el frente revolucionario. Le daría mucha fuerza el que se coaligaran con él las izquierdas gubernamentales. ${ }^{123}$

\section{NO A GIL ROBLES}

Desde que estalló la crisis, tras la dimisión de Joaquín Chapaprieta, la solución era Gil Robles. La alternativa era convocar elecciones. ${ }^{124}$ El 14 de diciembre destacó La Gaceta del Norte que Félix Gordón Ordás sostenía también esa salida.

123 Vidal i Barraquer-cardenal Pacelli, 1986. 1174-1179.

124 “Una pregunta llenaba ayer el ambiente: si estos sí, ¿por qué no Gil Robles?”, La Gaceta del Norte 13 de diciembre, 1. Alcalá Zamora anunció su deseo de formar un gobierno de concordia republicana. No era lo que había 
Cuando formó gobierno Portela Valladares, se ponía en marcha el último párrafo del artículo 81 de la Constitución: al excluir a Gil Robles, el presidente había hecho una segunda disolución innecesaria que obligaría a las nuevas Cortes a votar su destitución. ${ }^{125}$ Como declaró el jefe de la CEDA, la crisis fue el último asalto de la revolución a unas Cortes, donde la izquierda había perdido su mayoría. "La revolución, vencida en la calle, ha logrado enroscarse en nuestro armazón institucional". ${ }^{126}$

Se trataba de una crisis de régimen. La disolución y la convocatoria de elecciones eran un salto hacia lo desconocido. ${ }^{127}$ Alcalá Zamora contradecía su nota del 23 de septiembre, en la que hablaba del deber de evitar las elecciones, porque podrían ser un "un incentivo a la discordia"128.

El gobierno de Portela Valladares fue llamado por Miguel Maura "electorero" y "favorito del Jefe del Estado". ${ }^{129}$ Esperaba Portela obtener 150 diputados centristas. Era "un sueño". Había que reemplazar a un Presidente de la República que, transformando en acto sus palabras durante el debate constitucional, había llevado la política de conflicto en conflicto, hasta plantear la necesidad de desalojarlo de su alta magistratura. ${ }^{130}$

Portela transmitió el 3 de enero a Alcalá Zamora un mensaje de Manuel Azaña: estaban preocupados por los ataques y dificultades que la derecha estaba creando al Presidente de la República. Estaban a su lado y dispuestos a defender su autoridad. Esta era su reflexión: “¿Cuánto tiempo tardarán en acometerme a su vez estos amparadores de la izquierda?"131

Tras la formación del segundo gobierno Portela Valladares, parecía fracasada la apuesta de Alcalá Zamora por la creación de un centro político desde el poder. La sociedad española no estaba interesaba en esas soluciones intermedias. Se había polarizado. No cabía más que una victoria de las derechas o de las izquierdas. Será una victoria con mayoría absoluta.

respondido Unamuno a su consulta: un gobierno neutral, integrado por persona de alto crédito moral que presidiera unas elecciones. Especialmente dura fue la oposición a Miguel Maura, a quien también se encargó que formara gobierno. "Al sexto día... Película de la XIV a crisis", La Gaceta del Norte, 14 diciembre, 1.

125 “¿Por qué?”, La Gaceta del Norte 15 de diciembre, 1. Ese mismo día se anunciaba la dimisión de los miembros de la CEDA e informaba de la despedida de Gil Robles en el ministerio de la Guerra. Alcalá Zamora replicó el 16 de diciembre a la acusación de proceder contra la constitución en un discurso ante el nuevo gobierno. Una caricatura mostraba la vinculación de La Gaceta del Norte con Gil Robles. "El tango de moda", Euzkadi, 18 diciembre, 2 .

${ }^{126}$ Gil Robles repitió ese valoración en el discurso que pronunció el 19 de diciembre en el Teatro Calderón, de Valladolid: "Nos fue imposible desalojar a la revolución del alcázar del Poder". Un resumen, "Gil Robles inicia su campaña de propaganda electoral", La Gaceta del Norte 20 de diciembre, 3.

127 "La crisis política de España vista por "Le Temps", La Gaceta del Norte 18 diciembre, 12. La convocatoria electoral se definía como un "genial 'a ver qué pasa"'. "Anticipándose a una derrota en la Diputación permanente de as Cortes, Portela publica el decreto de disolución”, La Gaceta del Norte 8 enero 1936, 1.

128 "Evitar, eludir, retardar una convocatoria a elecciones", La Gaceta del Norte 9 enero 1936, 1.

${ }^{129}$ Un resumen de su discurso ante la Comisión permanente de las Cortes, el 7 de enero, Pla, J. 1941. Historia de la Segunda República, IV, Barcelona. 250-251.

${ }^{130}$ Miguel Maura en un acto de su partido en el Palacio de la Música, de Madrid, dijo el 13 de enero, que las próximas Cortes tendrían que enjuiciar a Alcalá Zamora.

${ }^{131}$ Alcalá Zamora, N. 2011. 3 de enero: 63. 
Las izquierdas regresarían al poder más radicalizadas. Si el resultado era un parlamento muy equilibrado, se produciría el caos. La lucha política saldría a la calle y se haría por medios no legales, apelando a la violencia, no sólo contra las propiedades, sino contra las personas. ${ }^{132}$

La convocatoria descalificó la labor política de las Cortes. El Presidente de la República quería conocer la respuesta del electorado al cambio operado en España desde las últimas elecciones.

El nuncio sostenía que las Cortes tenían una mayoría dispuesta a apoyar a un gobierno del partido radical. Habían hecho reformas importantes. La crisis del partido radical no era razón suficiente, porque dentro del bloque, que había sostenido a los gobiernos de Lerroux, Samper y Chapapietra, la CEDA estaba en condiciones de gobernar.

No lo quiso así Alcalá Zamora y no actuó constitucionalmente. Formó un Gobierno sin base parlamentaria. El nuncio sostenía la tesis, que luego servirá para destituir a Alcalá Zamora: había habido dos disoluciones de las Cortes. Esta tercera era inconstitucional. Podría aplicarse el artículo 81/4 de la Constitución en cuanto las Cortes se reunieran y proceder a la destitución del Presidente de la República. Para ese fin no sería difícil conseguir que las izquierdas y las derechas, enemistadas con Alcalá Zamora, llegaran a tener los tres quintos de los diputados.

La lucha electoral sería entre el PSOE y la CEDA. Había una novedad: la crisis política estaba beneficiando a los monárquicos. Las elecciones del 16 de febrero y del 1 de marzo serian decisivas. Una victoria de las derechas supondría no una reforma de la Constitución, sino .la aprobación de una nueva. Si la victoria era para las izquierdas, llegaría la revolución y la dictadura del proletariado. ${ }^{133}$

Unos días más tardes, sorprendió a Tedeschini el tono moderado del manifiesto electoral de las izquierdas. ${ }^{134}$

Ante el escaso rigor jurídico y la impunidad que las Cortes reunidas daban a los diputados monárquicos, se extrañaba Alcalá Zamora de la postura de Miguel Maura. José María Gil Robles obtuvo firmas para exigir la reunión de las Cortes. Alfonso Posada llamó el 5 de enero al Presidente de la República. Todo era legal. Este era argumento de peso mayor que la firma de alfonsinos y carlistas a las que se adhirió José María Gil Robles, que aportaba a los monárquicos el apoyo de los militares que le eran adictos.

Se hablaba de que el caudillo inicial de ese movimiento era el general Rafael Villegas Montesinos. Recibiría el apoyo del General Manuel Goded Llopis. No era desdeñable ese rumor, pese al juicio de Manuel Azaña, que consideraba Villegas "un escribano", una persona débil. ${ }^{135}$

El 9 de enero de 1936, Alejandro Lerroux y Melquíades Álvarez declararon ante la prensa que la disolución era "más o menos disimuladamente" un golpe de Estado. Melquíades Álvarez recordó que la Constitución no distinguía entre Cortes Constituyentes y ordinarias. Por eso el Presidente de la

1327802 Tedeschini-Pacelli, 3 enero 1936, ASV Arch.Nunz.Madrid 912 (4) 503-504.

${ }^{133} 7820$ Tedeschini-Pacelli, 15 enero 1936, ib 507-510.

${ }^{134} 7825$ Tedeschini-Pacelli, 20 enero, Ibídem 515

135 Rafael Villegas no era una persona decidida, como se vio en julio de 1936. Sus vacilaciones acabaron con su detención. Fue asesinado en La Modelo el 23 de agosto. Niceto Alcalá Zamora 5 de enero, Alcalá Zamora, N. 2011: 64-67. 
República había agotado las dos disoluciones. Tendría ahora que responder al acta acusatoria de quienes así pensaban. ${ }^{136}$

¿Qué razones tenía Alcalá Zamora? Aunque la composición de las nuevas Cortes apenas variara de las disueltas, políticamente, la decisión era justa, pues permitiría a la izquierda salir de su disgusto, a la derecha la oportunidad de legitimar "su título electoral republicano", a los radicales, liquidar la descomposición moral, que los inhabilitaba para seguir siendo centro y eje de las Cortes, como lo eran hasta ese momento.

Si se cumplían las expectativas de cambio, el nuevo centro, con su significación, independencia y dignidad, sería enlace y freno, sin claudicación política, pudiendo cooperar con él los partidos menos extremos. No podía entregar la República a quienes de ellos nada recibe ni votaron por ella.

La disolución la hizo inevitable José María Gil Robles. Ni por miedo ni por fanatismo podía entrega Alcalá Zamora la República a las derechas. ${ }^{137}$

La solución a la crisis política de finales de 1935 no estaba en manos de Alcalá Zamora. Tenía dos soluciones. La primera, un Gobierno presidido por Gil Robles. Era el jefe de la minoría más numerosa y podría ser apoyado por los radicales. Sería un Gobierno no de republicanos, sino de oportunistas. La segunda, disolver las Cortes confiando en el buen sentido político de los ciudadanos. Pero esto era esperar un milagro.

Ninguna de las dos salidas evitaba la Guerra Civil ni afianzaba la Presidencia de la República. Fuere quien fuere, el vencedor se sentiría agraviado por Alcalá Zamora y trataría de tomar su venganza. ${ }^{138}$

Visto los ataques de Gil Robles, Alcalá Zamora concluyó que ese lenguaje y esos conceptos llevaban a un partido de orden al terreno en cual los partidos del Frente Popular le llevaban ventaja. Si en el primer bienio fueron decisivos los excesos de la izquierda, en 1936 lo fueron la represión política y los excesos en lo social. Acción Popular toleró los abusos del Partido Radical y sus inmoralidades administrativas. Colaboró a que las Cortes, disuelta el 7 de enero se parecieran a una Cámara "fernandina".

Creyeron algunos que las izquierdas habían aprendido y no repetirían sus errores. No les será fácil eliminar el lastre sindicalista. Martínez Barrio tiene poco peso y el socialismo se había hecho extremista con Largo Caballero, que había desplazado a Julián Besteiro. Esa orientación la reforzaban la presencia de la Esquerra Republicana y las graves e incorregibles limitaciones de Manuel Azaña. Habrá que esperar el "saludo de la Bolsa". ${ }^{139}$

Pensó Azaña que, conseguida la victoria electoral, le sería fácil anular al PSOE y a la CNT. No tenía afinidad con estas dos organizaciones, ni siquiera en el deseo de promover la justicia social. "Me

\footnotetext{
${ }^{136}$ Notas Jorge Fernández-Coppel a Niceto Alcalá Zamora 3 de enero, Ibídem 74.

${ }^{137}$ Alcalá Zamora N. 2011.15 al 21 de enero, Ibídem 85-86 y 91-92.

${ }^{138}$ Cabanellas, G. 1978. Cuatro generales. Preludio de la Guerra Civil, Barcelona, Editorial Planeta.

${ }^{139}$ Alcalá Zamora. N. 2011. 18 de enero: 175-176.
}

81.

Hispania Sacra, LXIV, Extra I, enero-junio 2012, 69-148, e-ISSN: 1988-4265, doi: 10.3989/hs.2012.027 
ha dicho persona bien informada que Azaña, para imponerse como poder omnímodo, requirió sin éxito el apoyo del ejército a través de los dos hermanos generales Cabanellas". ${ }^{140}$

Alcalá Zamora se manifestó claramente en contra de una intervención política del ejército. Llevaría a la destrucción de España y del ejército. A diferencia de 1923, un golpe de estado encontraría oposición y esta "comenzaría en su forma más feroz. Por deber, patriotismo y convicción, por amor sincero al ejército, el Presidente de la República no sería cómplice de una rebelión militar. Si querían llevarla a cabo, debería antes echarlo. ${ }^{141}$

\section{EL GOBIERNO DEL FRENTE POPULAR}

EL 19 de febrero de 1936, el Presidente de la República abrió consultas para formación del nuevo Gobierno. A favor de uno del Frente Popular, estaban Manuel Azaña y Diego Martínez Barrio, que aconsejó que lo presidiera Azaña. Pi i Suñer dijo que debería formarse uno de izquierda republicana, dado que los socialistas no querían estar en él. Lo mismo manifestó Julián Besteiro. Un Gobierno dirigido por quien pueda tener mayoría en el Parlamento fue la escueta respuesta de José Martínez de Velasco.

Alejandro Lerroux dijo que el Presidente de la República tenía manos libres para encargar el Gobierno, a la vista de que el resultado dejaba niveladas las fuerzas de los dos grandes grupos de la Cámara. Joaquín Chapaprieta se limitó a recordar que el Gobierno debía reflejar la composición de la nueva Cámara

¿Debía continuar Portela? Sí, hasta la constitución de las nuevas Cortes, dijo Samper. Cabello, socialista, pidió que se entregara el Gobierno inmediatamente a quienes había ganado. Santiago Alba coincidía con Cabello: urge un Gobierno "con integridad de medios y plenitud de personalidad". Debía ser del Frente Popular y estar presidido por Manuel Azaña. Cambó sostenía esto mismo, pues "una demora podría ser de consecuencias funestas para España". Cabello recordó que "la más elemental discreción aconseja evitar los peligros que el retardo viene produciendo y que se han evidenciado en las últimas veinticuatro horas".

Alba pedía que el nuevo Gobierno fuera acogido "con un amplio margen de benévola expectación". Su programa le obligaba, pero, al realizarlo, debería inspirarse "en sentimientos de justicia y de orden, que son el común denominador de todos los partidos en una democracia digna de tal nombre".

La dimisión de Portela, según Samper, creaba a la presidencia "un conflicto circunstancial de difícil solución", En la misma línea que Cabello y Cambó, deberían encargarse los dirigentes de la izquierda republicana para calmar la impaciencia de las masas y asegurar el respeto a la Constitución. La amnistía no podía ser inmediata, porque el Gobierno ha de consultar antes a las Cortes. Otra salida, podría ser un Gobierno de funcionarios de prestigio, competencia y energía e inequívoca fidelidad a la República. Solo si esto no era posible, habría que acudir a los dirigentes de los partidos del Frente Popular. Sería una solución "forzada y anormal, y expuesta, por serlo, a posibles males irremediables. 142

\footnotetext{
${ }^{140}$ Alcalá Zamora, N. 1977: 358.

${ }^{141}$ Alcalá Zamora. N. 2011. 19 de enero: 175-176 y 182-183.

${ }^{142}$ Estas respuestas, en Alcalá Zamora. N. 2011.8 abril 1936 y epilogo: 435-439.
} 
En el Gobierno formado por Azaña el 19 de febrero de 1936 fue ministro de la Gobernación Amós Salvador Carreras. Extrañó a Alcalá Zamora este nombramiento, porque el elegido era "una pantalla para llevar Azaña mismo el ministerio", ya que había dejado el de la Guerra en manos del general Carlos Masquelet.

"Tal interpretación me tranquilizó equivocadamente, pues, con Azaña de tutor o curador, Amós fue lo que hubiera sido dejándolo en pleno libertad, o sea, la improvisación más inepta, negligente y dañosa de que haya recuerdo". ${ }^{14}$

Lo fue hasta el 13 de mayo. Le sustituyó Juan Moles Ormella.

No guardaba Alcalá Zamora rencor hacia Gil Robles. Lamentaba el quebranto que la causa del orden, el ejército, la paz, en el país de las guerras civiles, habían sufrido. Otros efectos fueron la quiebra de un sistema que asegurara una justa y equilibrada representación electoral, la tranquilidad financiera bursátil, el justo salario, base de una economía próspera, y la reforma de los desatinos constitucionales, la relación normalizada con la Iglesia ....Era una larga lista

Pocos días más tarde juzgaba que las elecciones habían consolidado la República. Estaban minando el régimen los tumultos y asaltos, que deterioraban mucho la confianza en el Gobierno. Creía que en una semana había cambiado la opinión y eso quedaría patente en unas elecciones con garantías.

Las Cortes, salidas de las elecciones, eran exaltadas. Habían ganado, pero su ventaja era exagerada. Quedó anulado el centro. Cabía que se prescindiera de Diego Martínez Barrio. Este reconoció que, en número de votos, la victoria del Frente Popular, fue modesta. Esto les obligaba a ser prudentes. Había en el cómputo total un saldo de 25000 votos a favor de todas las oposiciones reunidas. $^{144}$

En una visita a Alcalá Zamora el 28 de febrero, Martínez Barrio dijo a Alcalá Zamora que las elecciones se manipularon. El 6 de febrero la izquierda contaba con 217 escaños. El resultado final demostraba el falseamiento del escrutinio, favorecido por la huída de los gobernadores. Otros efectos de esa conducta fue el desorden. Martínez Barrio creía que debería procesarse a quienes abandonaron su puesto. ${ }^{145}$

El 24 de febrero el ministro de la gobernación le dijo que la situación mejoraba, pero al Presidente de la República le parecía que el Gobierno solo era obedecido cuando se plegaba a las demandas de los violentos.

Alcalá Zamora preparaba sus papeles para poder renunciar cuando llegara el momento. El 25 de febrero se reunió la Comisión Permanente de las Cortes. Convocó el Presidente de la República a un consejo de ministros para dos horas antes.

${ }^{143}$ Alcalá Zamora, N. 1977: 350.

${ }^{144}$ Alcalá Zamora, N. 2011, 19 y 24 de febrero y 8 de marzo: 195 y 205, 211 y 268.

145 Ibídem: 235, Sobre los efectos políticos, especialmente la radicalización de las izquierdas, 8 marzo, Ibídem: 368-370. Diego Martínez Barrio y Alcalá Zamora estaban de acuerdo al señalar los defectos de la ley electoral. 
La prensa de izquierdas el 26 de febrero presentó la amnistía como un paso previo a la Guerra Civil. Obtenía la impunidad para los suyos. Quiso extenderla a los presos comunes, a quienes exculpaba. Pero pedía el procesamiento de Gil Robles y de Salazar Alonso y de todos los que intervinieron en la represión de octubre de 1934. Se les olvidaba que ninguno de los dos era ministros en esa fecha. ${ }^{146}$

El decreto de suspensión de las Garantías Constitucionales se dejó en manos de los perturbadores, que marcaban a las autoridades su aplicación. Denuncio Alcalá Zamora la ventaja que El Liberal, de Indalecio Prieto, obtuvo. Era el único periódico no sometido a la censura. Había una "tolerancia de la anarquía". ${ }^{147}$

Tras la victoria del Frente Popular, el 3 de marzo Prieto hizo unas declaraciones en El Liberal de Bilbao. Quiso El Debate publicar un resumen. Lo tachó la censura. Prieto decía que era urgente la reforma de la Constitución para dar al Presidente mayores poderes. Anunciaba que eso suponía la elección de un destacado jurista del PSOE. Había demás un programa de reformas que se pondrían en marcha de inmediato. Tras las elecciones municipales y provinciales, vendría la disolución de las Cortes y nuevas elecciones para finales de año. El Socialista culpaba a Alcalá Zamora de injerencia en la acción del ejecutivo y de haber retrasado la convocatoria de elecciones. ${ }^{148}$

El Gobierno presentó al Presidente de la República un decreto sobre readmisiones de despedidos tras la revolución de octubre. Había tres fórmulas, todas ilegales. Lo había consultado Manuel Azaña con Felipe Sánchez Román. ¿Por qué no lo retiró Manuel Azaña? Porque el Gobierno en esa fecha ya no era dueño de sus decisiones. Era previsible el cierre de empresas. La Hacienda Pública estaba averiada. Se quería cargar sobre ella el coste de la medida. Era un ejemplo de las "prodigalidades" del Gobierno desde que tomó el poder.

Este Gobierno tutelado gobernaría sin autoridad, humillado, sin orden ni sistema. Manuel Azaña ¿se marcharía o resistiría en el Parlamento? La conclusión de Alcalá Zamora es demoledora. Al hombre le faltaba corazón, y, en el gobernante, no había esas cualidades que no podía suplir "el engreimiento personal, ilimitado".

Cuando se atentó contra Jiménez Asúa, comentó Alcalá Zamora el 12 de marzo: la cadena de actos terroristas muestra que el Gobierno nada hace. Es como si no existiera. Lo soportaba como Presidente de la República, porque, aun siendo "el reflejo de una mayoría ficticia", existe. Esta mayoría quería declarar indisolubles las Cortes. ${ }^{149}$

El 5 de marzo de 1936 el Tribunal de Garantías Constitucionales declaró inconstitucional la ley del 2 de enero de 1935, que suspendió la autonomía de Cataluña. Alcalá Zamora lo advirtió en su momento. Las competencias de orden público estaban compartidas entre el Estado y la Generalidad. ${ }^{150}$

${ }^{146}$ Ibídem 24-25 febrero, 214-215 y 219-220.

${ }^{147}$ Alcalá Zamora, N. 1977: 352-353 y 258.

${ }^{148}$ El texto censurado lo envió a Tedeschini Francisco de Luis, director de El Debate, 6 marzo 1936, ASV Arch.Nunz.Madrid 945 (3) 347 y 351 Texto completo que se envía a Roma, 7909 Tedeschini-Pacelli, 24 marzo 1936, Ibídem 912b (5) 627-628

${ }^{149}$ Alcalá Zamora, N. 2011. 3, 10 y 12 marzo 1936. 249-250, 281-282 y 283.

${ }^{150}$ Ibídem 5 marzo 1936. 267-268. 
Seguían los desórdenes públicos. En Alcalá en la noche del 5 al 6 de marzo, incendiaron la iglesia que fue de los jesuitas, el convento de las magdalenas, la iglesia de Santiago y se intentó con la iglesia de San Esteban y la de los Carmelitas. El 5 un grupo de agitadores se adueñó de la ciudad. Pudieron actuar a su antojo. Pidió fuerzas el alcalde, pero no se enviaron hasta muy avanzada la noche. En Alcalá había dos regimientos de Caballería. Cuando las tropas salieron a la calle, se restableció el orden, sin que hubiera heridos. ${ }^{151}$

Se entrevistaron Azaña y Largo Caballero. El gobierno del Frente Popular tendrá problemas. Los trabajadores no se quedarán pasivos, sometidos a la "explotación capitalista". Los amigos de Azaña estaban cada día más descontentos. Así las cosas, Amós Salvador Carreras, ministro de la Gobernación, se decidió a hablar. Lo hizo en "términos de una pobreza mental inconcebible". Era un "caso de improvisación y favoritismo doméstico no igualado". ${ }^{152}$

A la noche del 14 de marzo había incendios en Madrid. Nadie lo impedía, ni siquiera el de la iglesia de San Luis, que estaba enfrente del Ministerio de la Gobernación. La gente esperaba la declaración del estado de guerra. El Gobierno quería mantener desinformado al Presidente de la República. Esta fue la versión que le dio el ministro de la Gobernación: las manifestaciones son pacíficas. Al acabar un grupo provoca los incendios. Era "un deporte", según Amós Salvador. Uno de los conventos incendiados fue el de las trinitarias de la Calle Lope de Vega. Allí está enterrado Cervantes.

Las noticias hablaban del terror de los incendiarios y del abandono del Gobierno. Estaban asustados los religiosos y los vecinos de sus conventos. Hubo muchos heridos. Los incendiarios eran unos "mozalbetes". Los observadores tenían la misión de impedir el acceso de los bomberos. Unas parejas vigilaban la llegada de las fuerzas de orden. Iniciaban los disparos contra ellas y así avisaban a los otros pistoleros. El general Fernando Martínez Monge, en quien confiaba el Gobierno, comentó a Alcalá Zamora la agitación que había entre los oficiales de Madrid.

El Presidente de la República habló con Azaña. Había que garantizar el orden, pues "la prolongación intolerable y tolerada de la anarquía podría traer una reacción que arrolle todo el régimen”. El General de la I División y todos los mandos, reunidos bajo su presidencia, había acordado decir esto mismo al Gobierno.

Alcalá Zamora dijo al general Domingo Batet que el ejército debía mantener la prudencia y el respeto al poder civil. Anunció que no conviviría "con nada que sea un golpe de Estado". Parecía haberse tranquilizado la situación. ${ }^{153}$ El 20 de marzo, Luis Nicolau de Olwer, gobernador general del Banco de España, visitó a Alcalá Zamora para entregarle la memoria. Le comentó que la mayoría en las Cortes facilitaba una variación política. Alcalá Zamora volvió a su argumento y a su preocupación: la ausencia de un centro político dejaba al Gobierno en manos de sus aliados extremistas. Nicolau replicó: "lo imposible será vivir sin ellos".

Abiertas las Cortes, procurarían que el Presidente de la República siguiera como "una garantía frente a la disolución", que podría decidir otro. Así, no pudiendo ser disueltas por Alcalá Zamora, la izquierda se asentaría en el poder. No saben vivir fuera de él.

\footnotetext{
${ }^{151}$ Ibídem 6 marzo 1936. 256-257.

${ }^{152}$ Ibídem 13 marzo 1936. 285.

${ }^{153}$ Ibídem 18 marzo 1936. 288-297.
} 


\section{¿UN GOLPE DE ESTADO “PARLAMENTARIO”?}

Había un ambiente de "anheloso pesimismo. Su permanencia como Presidente de la República la califica Alcalá Zamora "esperanza de la desesperación". Había señales de acercamiento por parte de algunos elementos de la CEDA, Herrera y la gente de El Debate. Junto a este "republicanismo más franco, este sector lamenta las inconcebibles locuras de propaganda y táctica a que suicidamente se entregó Gil Robles". Manuel Giménez Fernández, que podría haber sucedido a Gil Robles como jefe de la CEDA, lo visitó el 22 de marzo. No votarían contra Alcalá Zamora y estaban dispuestos a presentar una votación incidental de "no ha lugar a deliberar" y hasta a someter el asunto al Tribunal de garantías. Sus vocales en él sostendrían la permanencia del Presidente de la República. ${ }^{154}$

Pocos días antes de plantear la destitución de Alcalá Zamora faltaban votos para los $3 / 5$ de los diputados, según la cuenta hecha por Manuel Azaña. ¿Estaba este por esa operación? Se preguntaba Alcalá Zamora si ahora daría marcha atrás. Eso supondría cancelar su error, rectificando su postura en la oposición.

El 15 de marzo, el cardenal Vidal i Barraquer escribió a Manuel Azaña. Era una amarga y enérgica protesta del cardenal "más antiguo de la Iglesia en España". Habla de "bárbaras violencias" de la visible pasividad y negligencia en prevenirlas por parte de quienes deben asegurar la libertad y el honor de los ciudadanos y de las instituciones. No se ha respetado el carácter sagrado de los templos, ni la libertad religiosa, ni la dignidad de las personas ni siquiera los monumentos, "cuya pérdida afrenta con el peor de los estigmas a todo un pueblo y al poder que la consiente".

La Iglesia, en bien de la paz, ha sido respetuosa con el poder. Ha buscado una decorosa armonía, a pesar de que el Estado ha aprobado una legislación vejatoria e injusta. Ha sido, dentro de la legalidad española, "paciente, patriótica y generosa". Se caminaba hacia la anulación del poder público, quedando en manos de la violencia agresora y de la reacción defensiva de unos ciudadanos que jamás pierden su derecho a existir con seguridad y dignidad". Los órganos del Estado deben atentos solo a los fines de la justicia y de la equidad, impuestos por el supremo bien del país.

Esta protesta no deseaba dificultar "la actuación reparadora del Gobierno" para mantener la paz.

En la tarde del 31 de marzo, visitó a Alcalá Zamora. El cardenal Vidal i Barraquer le aconsejó que siguiera en su puesto, mientras pudiera estar con dignidad y eficacia. No se trataba de seguir a todo trance. Los que abogan por la resistencia parecen olvidar que esta podría ser inútil y hasta contraproducente. ${ }^{155}$

El 30 de marzo recibió Alcalá Zamora a Joaquín Chapaprieta. Este le insistió en que continuara. Debía resistir todos los ultrajes, porque, escribe Alcalá Zamora, "soy la principal y única defensa de la nación y la República". Si tenía que enfrentarse solo a la deserción, por miedo o por sectarismo, de los ministros de Manuel Azaña, una vez restablecida la normalidad y la ley, su retirada se entendería como un deber, no como un acto de egoísmo. Chapaprieta le dijo que nombrara un nuevo Gobierno con el

${ }^{154}$ Ibídem 18, 20 y 22 marzo 1936. 314, 321 y 326.

155 Ibídem 27 y 31 marzo 1936: 314, 321 y 347, 360 y anexo con el texto del el cardenal Vidal i Barraquer, Ibídem 448-449. La muy negativa impresión que fuera de España causaban estos hechos la comentó Barcia a Alcalá Zamora el 23 de marzo, Ibídem 328-329. 
apoyo "de la fuerza armada" para restablecer el orden y la autoridad. Tenía razones sobradas. El parlamento y la calle presentaban "síntomas seguros de más graves y bien próximos y, desde luego, irremediables males".

No lo haría. Un golpe de Estado le obligaría a dejar la presidencia y, aun hecho por sorpresa, "aumentaría los estragos y las resistencias de la lucha". ${ }^{156}$

Mientras los ayuntamientos tomaban acuerdos sobre expropiación y ocupación de templos, en contra de la Ley de Confesiones y Congregaciones Religiosas, el ministro de Justicia endosaba la responsabilidad al de Gobernación.

Sentenciados quienes dispararon contra la casa de Largo Caballero, Alcalá Zamora preguntó si se había puesto recurso de casación. Había que corregir los errores judiciales. Eso obligaba incluso cuando lesionaban derechos de adversarios políticos.

La situación estaba peor en el ámbito local y provincial. El Gobierno funcionaba mejor pero su acción se notaba apenas en Madrid, pues “...los gobernadores son detestables y anarquizantes, en general, por sectarismo, ineptitud o miedo; y las deficiencias de esa autoridad, tan importantes, se agravan en los pueblos". Los alcaldes eran "los más intrusos y forajidos".

La jornada del 12 de abril de 1931 fue de concordia, esperanza y entusiasmo. Cinco años más tarde, el Frente Popular había ganado las elecciones con un tercio del censo, Los poderes legislativos estaban sometidos a una Constitución en vigor. Las Cortes recién elegidas. Las oposiciones se habían abstenido. No podían concurrir "bajo un régimen de terror tumultuario". Muchos, privados de su derecho de propiedad y hasta de su domicilio, eran amenazados de muerte. No entregaría la prerrogativa de nombrar un nuevo Gobierno ni el poder a "la presión irresponsable y delictiva".Eran su determinación y su deber.

La posibilidad de destitución del Presidente de la República, según Azaña, era un instrumento o un pretexto para mantener la tensión entre los partidos. Más allá de la querella personal, creía Alcalá Zamora que había dos motivos: el ansia de la izquierda de quedarse con todo el poder, a la se oponía la su imparcialidad institucional, $y$, en segundo lugar, que su condición de creyente practicante, liberal, demócrata y tolerante. Y esto no puede agradar a quienes quieren un Presidente de su afiliación.

"Cada día se anunciaba para la noche inmediata" un golpe militar. Azaña, entre sarcasmos e inquietudes, "dice que no cree en ello". No lo creía el ministro de la Guerra ni el Director General de Seguridad. O lo llevaban tan oculto que "no puede percibirse ni el humo", o no existe. Alcalá Zamora no lo esperaba, porque "quien primero se salga de la ley, sea por el lado que fuere, cometerá un acto de suicidio, menos explicable en colectividades más reducidas, disciplinadas y conscientes"., como el ejército. ${ }^{157}$

Azaña declaró en las Cortes: "nos hemos encontrado el 19 de febrero del año 36 con un país abandonado por las autoridades". "Semanas antes, respondió a Tedeschini que los incendios y saqueos contra edificios de la Iglesia se debía a la falta de conexión entre las autoridades del Gobierno

\footnotetext{
${ }^{156}$ Ibídem 30 y 31 marzo 1936. 408.

${ }^{157}$ Ibidem, 2 abril 1936: 371, 374-376 y 370.

${ }^{158}$ DS/C (3 abril 1936) 223.
} 
anterior y las nuevas. Se había vuelto a los ayuntamientos elegidos en abril de 1931. Todo eso había permitido a los facinerosos "cometer aquellos desmanes". Ahora iba a restablecerse el orden. ${ }^{159}$

El 3 de abril se vieron Azaña y Alcalá Zamora en casa de éste. Le llevaba el decreto de suspensión de las elecciones municipales. Esa decisión significaba para Alcalá Zamora un triunfo de la justicia, de la paz y de la República. Azaña le informó de una conspiración en marcha, cuyo jefe es Sanjurjo.

El ejército portugués estaba concentrando tropas y armamento para favorecerla. Los datos parecen inverosímiles. Para restarles crédito, Alcalá Zamora añade que el día anterior Azaña había dicho que Queipo de Llano, Inspector General de Carabineros, la capitaneaba. Cree que es una nueva manifestación de su antipatía, porque el general es consuegro del Presidente de la República. Dos días después habla de sus "desatinados temores".

Creía Miguel Maura que Martínez Barrio estaba interesado en la destitución de Alcalá Zamora por razones económicas. De posición modesta, podría, durante dos meses, disponer de la asignación del Presidente de la República. Alcalá Zamora admiraba la sobriedad con que siempre había vivido Martínez Barrio, siempre obediente a los mandatos de la masonería. ${ }^{160}$

El 7 de abril se presentó la proposición. El primer firmante era Indalecio Prieto. Hubo un largo debate. Se aprobó. De los 418 diputados, votaron 243, en contra, 5 y 238 a favor. ${ }^{161}$ A las 11,55 de la noche, se levantó el acta de la notificación dada al Secretario General de la Presidencia, Sánchez Guerra, en el Palacio Nacional. ${ }^{162}$

Había fracasado el proyecto político de Alcalá Zamora. ${ }^{163}$ Los acontecimientos aceleraron algunas decisiones. Estaba previsto que el embajador de Brasil se encargara de la nunciatura. ${ }^{164}$

El artículo 68 de la Constitución regulaba la elección de compromisorias para elegir al Presidente de la República. ${ }^{165}$ La del 26 abril de 1936, la denunció Alcalá Zamora como una "farsa". ${ }^{166}$

159 Azaña-Tedeschini, en respuesta es la nota del nuncio a quien en esos momentos hacía funciones de ministro de Estado, 14 de marzo 1936, ASV, Arch.Nunz.Madrid 925 (2) 354.

160 Alcalá Zamora. N. 2011. 2, 3 y 4 abril 1936: 383-384

161 “... los diputados que suscriben, atentos únicamente a la suprema razón política de asegurar en todas las instituciones del Estado republicano la observancia y la defensa de la Constitución, pospuestas al urgente cumplimiento de aquel deber todas las demás consideraciones que pueden emanar del planteamiento de la última contienda electoral propone: que las Cortes, para los fines del último párrafo del artículo 81 de la Constitución, declaren que no era necesario el decreto di disolución de las Cortes de 7 de enero de 1936". DS/C 15 (martes 7 de abril 1936) 242-271.

${ }^{162}$ Martínez Saura, Santos 1999. 289-355.

${ }^{163}$ Colocarse en el centro con la pretensión de contener lo mismo a las derechas que a las izquierdas es favorecer a las izquierdas, como el señor Alcalá Zamora ha tenido que hacerlo, aunque no fuera su propósito".Ramiro de Maeztu, "El poder moderador”, ABC, 16 abril 1936, en González Cuevas, Pedro Carlos. 2003. Maeztu. Biografía de un nacionalista español, Madrid, Marcial Pons. 346-347.

164 Alcalá Zamora, N. 2011. 7 abril 1936. 404.

165 "El Presidente de la República será elegido conjuntamente por las Cortes y un número de compromisarios igual al de Diputados.

Los compromisarios serán elegidos por sufragio universal, igual, directo y secreto, conforme al procedimiento que determine la ley. Al Tribunal de Garantías Constitucionales corresponde el examen y aprobación de los poderes de los compromisarios". 
No participó la oposición. No hubo fiscalización de las mesas. Hubo desinterés en los electores. Los elegidos eran personas de escasa significación, "fueron el pucherazo más gigantesco que la historia del sufragio universal registra en España”. Nadie protestó esos resultados. ${ }^{167}$

El 30 de abril Azaña fue elegido candidato único a la Presidencia de la República de todos los partidos del Frente Popular. Fue elegido el 10 de mayo de 1936 con 754 votos de los 874 compromisarios y diputados. Prometió el cargo al día siguiente.

Los ministros se quejaban según Miguel Maura, de las cosas tan duras que tenían que oír del Presidente de la República en los consejos, especialmente la condena de su tolerancia, de sus actos y omisiones. Le negaron que lo hiciera con elevación de miras, pensando en el más alto interés de España y de la República.

"El liberalismo de mi espíritu me ha llevado a tener en la Presidencia funcionarios de todos los matices, desde la extrema derecha republicana hasta la extrema izquierda marxista, sin tener yo duda sobre la ideología de nadie..."168

La tentación totalitaria de la izquierda, manifiesta en su planteamiento de la Ley Electoral de la República, presentada por el Gobierno Azaña en julio de 1933, tuvo su puesta en escena en abril de 1936. Indalecio Prieto propuso que las Cortes se declararan indisolubles. Querían controlar ellas la elección del nuevo presidente en diciembre de 1937. El paso siguiente fue destituir a Alcalá Zamora por haber ido a una tercera disolución, la de enero de 1936, contando como primera la convocatoria a Cortes Constituyentes en mayo de 1931.

"Era moral y jurídicamente tan inadmisible como censurable tamaña contradicción" con la actuación de los partidos, que aceptaron la convocatoria en octubre de 1933. Los ministros que estaban en el Gobierno que aprobó la convocatoria se sumaron a la votación contra el Presidente de la República. E1 7 de abril se "produjo un golpe de estado parlamentario". Lo hizo la mayoría del Frente Popular, sin esperar a la segunda vuelta electoral.

A las 11 de la mañana del 8 de abril, lo visitó un coronel de Estado Mayor. Frente al golpe dado por las Cortes, el ejército estaba dispuesto a responder. Pedía a Alcalá Zamora que firmara un decreto destituyendo el Gobierno presidido por Azaña. De ese modo, proporcionaría a los militares más fuerza. Acabarían con la anarquía. Lo tenían decidido.

Se negó, porque quería cumplir su deber. Había tomado ese camino y no deseaba que alguien pudiera pensar que actuaba por ambición. Con eso se evitaba. Alcalá Zamora comenta:

${ }^{166}$ Estos los resultados en Madrid: Castrovido (IR) 194.241, 83,04\%; Serrano (IR) 193.746, 82,83\%, Salmerón (IR) 193.679, 82,80\%; Ballester (IR) 192.996, 82,51\%; Rodrigo (UR) 192.671, 82,37\%; Menéndez (PSOE) 188.968, 80,79\%; Lois (PSOE) 188.713 80,68\%; Mazón (PSOE) 188.633, 80,64\%; Cabo (PCE) 188.586, 80,62\%; Muñoz (PSOE) 188.434, 80,56\%; Cantos (PSOE) 187.946, 80,35\%; Del Rosal (PSOE) 187.816, 80,29\%; Díaz Alor (PSOE) 187.770, 80,27\%; Tarofo (conservador rep.) 27.968, 11,96\%; Lafora (conservador rep.) 27.915; 11,93\%; Robles Romero-Robledo (conservador rep.) 27.907, 11,93\%; Moreno (conservador rep.) 27.883, 11,92\%. En blanco 12.840 5,49 Varios 808 0,35

167 "Los defectos de la Constitución de 1931" y "Tres años de experiencia constitucional", Alcalá Zamora, N. 2002. 125.

${ }^{168}$ Alcalá Zamora, N. 1977. 248 y 2011, 5 abril 1936, 396-397. 
"Queda tranquila mi conciencia, sobresaltado mi patriotismo ante el desastre hacia el que va esta Cámara codiciosa, que va a exigir a quien elija el compromiso secreto de no disolverla, garantizado por la discusión firmada".

Sabía que la opinión no entendería su gesto. Se lo reprocharía. Tenía la razón y le ofrecían la fuerza para acabar con el golpe parlamentario. El voto de las Cortes privó de legitimidad a la República. Fue su acta de defunción. Abría la vía a una dialéctica "salvaje, navajera, de simple violencia". El pronunciamiento del 18 de julio encaja y se explica así: media España contra la otra media. $^{169}$

¿Qué diferencia a Alcalá Zamora y a Manuel Azaña? Fueron los dos primeros y único presidente de la II República, con residencia en España. Coincidieron en el Comité Revolucionario, en el Gobierno Provisional y, en 1931-1933 Manuel Azaña formó Gobierno bajo la Presidencia de Alcalá Zamora, que le dio otra vez el encargo el 19 de febrero de 1936.

¿Qué les separaba? ¿Dos modos de entender el liberalismo?

"En conclusión: el antagonismo entre Azaña y Alcalá Zamora reconoce una raíz de talante transcendental: el permanente liberalismo moderado de este frente al liberalismo estatal de aquel". ${ }^{170}$

En este lenguaje, filo orteguiano, se plantea la posibilidad de que pueda haber un liberalismo estatal. Si se utiliza el Estado para entrar en el campo de las libertades, hay otro modelo, pero su legitimidad no puede llamarse liberal. Liberalismo y democracia no se identifican. Esta ha funcionado como legitimación de sistemas que han violado las libertades del individuo "pro bono rei-publicae", "pro salute rei publicae".

Quizás este dato pueda responder sobre el liberalismo de Alcalá Zamora. Recordando a Cavour, citado en otro lugar, una de las claves de su resistencia a la destitución fue mantenerse en la línea que se había trazado: absoluto alejamiento de todo lo que propicie la Guerra Civil. Por eso se negó a proclamar la legalidad de los poderes que se auto-designaban republicanos, cuando en 6 de octubre de 1937, Ángel Ossorio se lo pidió. ${ }^{171}$

Fue tan agónicamente exquisita esta posición, que, en medio de la pobreza, marchó del exilio de Francia al de Argentina, sin aceptar nada que lo distinguiera de la gente de abajo. Alcalá Zamora, siempre jurista y amante de la justicia, había "residenciado" el derecho y la justicia en el solar, reducido, provisional, amenazado siempre, en donde se hallan los humillados, los amenazados, los desprotegidos. Su cristianismo se proyectada hacia atrás, en el recuerdo de quien anunció: lo no violentos un día poseerán "la tierra".

\section{UNA “REPÚBLICA LIBERAL Y PARLAMENTARIA”}

\footnotetext{
${ }^{169}$ Ibídem 1977. 8 abril 1936 y epilogo: 410-411 y 415-416.

170 Alcalá Galve, Ángel 2006. Alcalá Zamora y la agonía de la República, Sevilla, Fundación José Manuel Lara, segunda edición: 449.

${ }^{171}$ Alcalá Zamora, N. 1977. 411.
} 
El mandato de Alcalá Zamora, iniciado el 11 de diciembre de 1931, duraba seis años. Tenía el proyecto formar una fuerza política de centro, capaz de intervenir con propuestas positivas. Pensaba anunciarlo el domingo 12 de diciembre de 1937. Eso daba continuidad a su esfuerzo para seguir frenando los excesos y las furias, favorecidos por "la tiranía alternada de la Cámara única y los inmensos desatinos del sistema electoral”.

No había lugar. Tras su destitución el 7 de abril de 1936, quedaron suspendidas todas las libertades públicas e inmediatamente estalló la guerra.

Las Cortes, que habían actuado como tribunal contra el Rey no se atrevieron a acusar a Alcalá Zamora. Lo destituyeron recurriendo a un procedimiento oblicuo: la segunda disolución. Esta y la anterior, demostraron que el Presidente de la República supo captar el cambio en la opinión. Los electores cambiaron la mayoría parlamentaria en 1933. El sistema mayoritario agrandó el efecto de ese giro político.

Durante sus poco más de cuatro años como presidente, "las controvertidas maniobras" de Alcalá-Zamora había contribuido a impedir que la derecha autoritaria o la izquierda revolucionaria se accedieran al control de Estado.

"Su apuesta por la República liberal y parlamentaria, ${ }^{172}$ que le obligara en alguna ocasión a forzar al máximo la elasticidad de la Constitución, le había ganado enemigos en todas partes". En 1936 se había quedado "casi solo". Sus enemigos habían ganado. Las elecciones de febrero abrían una incógnita. Según Gil Pecharromán, podría felicitarse Alcalá-Zamora de que se celebraran dentro de la normalidad democrática. ${ }^{173}$

En varias ocasiones en 1937, Alcalá Zamora atribuyó al sistema electoral una de las causas de la guerra civil. La misma Constitución, "ese instrumento de destrucción”, fue su primer y más grave resultado. Las Cortes salidas de las elecciones de junio de 1931 no representaban fielmente la voluntad nacional. Alcalá Zamora conocía, por una estadística de la Secretaría de las Cortes Constituyentes, anomalías como que un escaño costaba al PSOE 20000 votos y a otros partidos, 50000 y hasta 100000 .

A sabiendas de esto, las Cortes Constituyentes se lanzaron a extremismos que provocaron oposición a la República, nacida casi sin enemigos. Reconociendo incluso que su mayoría era ficticia y pasajera, se propusieron, fanáticamente, aprovecharse, haciendo una Constitución minuciosa, extensa, sobrecargada de detalles, y prácticamente irreformable.

El resultado de este modelo, que favorece la existencia de dos partidos o de dos alianzas de partidos, se vio en noviembre de 1933: el electorado fue empujado a posturas extremas, dejando sin apoyo a los "partidos medios".

${ }^{172}$ En enero de 1939, exiliado en París escribió sobre el futuro, cuando acabara la guerra civil: quedará como herencia la fuerza de los odios, que deja "una guerra sin freno moral y asoladora de todo el territorio" de España. Se impondrá la razón de Estado como norma suprema, porque se cree que la "única forma de convivencia consiste en que avance el exterminio y desparezca la ciudadanía. Crecerá la separación entre gobernantes y gobernados, la distancia entre opresores y oprimidos. ¿Qué podrían hacer quienes defienden el derecho de las minorías, el papel y dignidad de la oposición, los frenos y las limitaciones del poder?

${ }^{173}$ Gil Pecharromán, J. 2005. 360 y la cita anterior, 380. 
Alcalá Zamora, en uso de su prerrogativa constitucional, ${ }^{174}$ en septiembre de 1935, intentó que este asunto se examinara. "La ceguera, más que el egoísmo, de los partidos hizo fracasar la convocatoria". Recurrió entonces a otra de sus prerrogativas: proponer al Congreso un decreto. ${ }^{175}$ Aconsejó elegir bien un modelo de representación proporcional corregido. Era una solución ecléctica para impedir el enfrentamiento entre los extremos. "No me escucharon, una vez más, y lo que siguió fue la guerra civil".

Todos creían que ganarían, por eso se mostraban a favor de reducir el papel de las minorías, hasta suprimirlas. Lo intentó el Gobierno de Azaña en el verano de 1933. Por eso urgió al Gobierno que se exigiera una mayoría del $40 \% \mathrm{y}$, si no se alcanzaba, ir a una segunda vuelta. Así fue. En las elecciones del 19 de noviembre y del 3 de diciembre, la derecha tuvo 212 de los 473 diputados del Congreso.

En 1935 se opusieron a la reforma los partidos intermedios. Fue su condena a desaparecer.

Alcalá Zamora apostaba por una representación proporcional "absolutamente necesaria cuando hay entre los partidos extremos y poderosos divergencias profundas e inconciliables, que sobrepasan con mucho el alcance de una modificación constitucional. Entonces es necesario favorecer la estabilidad política y social del Estado e impedir su derrumbamiento".

Por eso debe favorecerse a los partidos medios. Los "de la fe sentida y de la tolerancia práctica", que creen en un ideal y son realistas. ${ }^{176}$

Durante su mandato logró evitar la guerra civil. Si no lo hubieran acortado las Cortes, cabe pensar que España no la hubiera sufrido. ¿Por qué no resistió frente a las Cortes? Porque juzgó que eso significaba irremisiblemente la guerra. Aceptar la destitución dejaba una esperanza de impedirla.

Quiso seguir sus reflexiones y hacer sus propuestas de reforma de la Constitución, aun a sabiendas de que el acto del 7 de abril era el final de régimen constitucional. No habría lugar a la negociación y a la transacción en la reforma. La Constitución se hundió semanas antes de que comenzara la guerra.

Rota la legalidad y los valores que aseguran la paz, el vencedor aplastaría a su enemigo. El poder era la suprema razón de Estado. Se anularían los derechos cívicos. La diferencia entre gobernantes y gobernados daría paso a la que hay entre opresores y oprimidos.

174 “El Presidente de la República podrá convocar al Congreso con carácter extraordinario siempre que lo estime oportuno" (Artículo 81)

175 "Cuando no se halle reunido el Congreso, el Presidente, a propuesta y por acuerdo unánime del Gobierno y con la aprobación de los dos tercios de la Diputación Permanente, podrá estatuir por decreto sobre materias reservadas a la competencia de las Cortes, en los casos excepcionales que requieran urgente decisión, o cuando lo demande la defensa de la República.

Los decretos así dictados tendrán sólo carácter provisional, y su vigencia estará limitada al tiempo que tarde el Congreso en resolver o legislar sobre la materia" (Artículo 80)

176 Alcalá Zamora, N. 2000. “¿Eclecticismo electoral?” y “Oportunismo electoral”, L'Ére Nouvelle, 25 enero y 2 febrero 1938, "Confesiones de un demócrata”, Obra Completa...94-96 y 97-99. Sobre la necesidad de perfeccionar el Estado para reforzar la nación, denunciando como camino inverso el seguido con la Constitución de la República, "Salvación de la Nación y reforma del Estado", Ibídem 8 abril 1938, 176

Hispania Sacra, LXIV, Extra I, enero-junio 2012, 69-148, e-ISSN: 1988-4265, doi: 10.3989/hs.2012.027 
En enero de 1938 Alcalá Zamora afirmaba su voluntad de proseguir la lucha por la justicia. Ahora tenía que hacerlo desde "el abismo que ha abierto la odiada y odiosa guerra civil". ${ }^{177}$

A las pocas semanas de ser destituido de la Presidencia de la República, Alcalá Zamora escribió:

"Lo que fue y significa la República del 14 de abril me parece claro, indiscutible. Voluntad nacional, libre y decisiva, es decir, soberanía efectiva; solidaridad patria y republicana por encima de los partidos, o sea, una legalidad común a estos: ausencia de odios y de excesos, que afirma la convivencia humana, confiada a la garantía de la justicia; rumbo hacia adelante, pero regido por una decisión consciente, que fija el ritmo y no aplasta vencidos; violencia excluida y guerras civiles terminadas y fuerza obediente. Eso es el espíritu del 14 de abril". ${ }^{178}$

Todo eso se lo llevó la Guerra Civil. Entre los muchos ejemplos, el de los nacionalistas vascos y sus socios en el Gobierno de Euzkadi. Cuando se acercaba la ofensiva contra Bilbao en junio de 1937, el Gobierno de José Antonio Aguirre dispuso el embarque forzoso de toda la riqueza inmobiliaria depositada en los bancos de la ciudad. Su valor superaba varios miles de millones. A la riqueza desplazada de la provincia de Guipuzcoa en septiembre de 1936, se sumaba la de aquellos que habían elegido el País Vasco para beneficiarse de las ventajas fiscales que aquellas provincias tenían.

Admitido que el Gobierno no se lucraba, esa decisión suponía una ilegítima incautación que tenía un previsible destino, "inmoral y catastrófico en grado sumo": continuar la guerra.

A esa ilegalidad se sumaba la del "apresurado y tan discutible Estatuto". Era un golpe mortal al fundamento ético e histórico más fuerte de la autonomía vasca": su apelación a las "Leyes Antiguas “. .179

Para esa misma catástrofe, se emplearon las reservas del Banco de España. La casi totalidad del oro existente en España el 17 de julio fue a parar a manos del "gobierno andariego". Este se apoderó abusivamente de las reservas del Banco de Emisión. A eso se suma el saqueo organizado en las poblaciones más ricas del país, con despojo del patrimonio artístico y la apertura forzada de cajas de caudales o depósitos bancarios. En estos, la incautación expoliadora se extendió a divisas y a joyas.

La Guerra Civil facilita la comisión de delitos. Uno de ellos, muy común, el asalto al patrimonio del Estado y saqueo de patrimonio de las personas privadas. Eso pasó en las semanas posteriores a julio de 1936. En el caso de la Guerra Civil se agrava con la existencia de dos tesorerías: más gastos y mayor urgencia de recursos. ${ }^{180}$

177 Alcalá Zamora, N. 2003. "Los propósitos de mi vida" e "Ideal truncado de una existencia", La Nación, 29 diciembre 1937 y 25 enero 1938, “Artículos publicados en el diario "La Nación” (Buenos Aires, 1936-1939), 146-152.

${ }_{178}$ Alcalá Zamora,’La República del 14 de abril y su esencia”, La Nación, de Buenos Aires, 28 junio 1936, en Alcalá Galve, A. 2006. 205

179 Alcalá Zamora, N. 1976. 389-390 y 394. Sobre la apertura de su caja fuerte en el Banco HispanoAmericano, ejemplo de violación y el valor inculpatorio de lo que en ella hubiese, Ibídem 410.

180 Alcalá Zamora, N. 2000. "Régimen político de convivencia en España, 1945, 200-201. Apareció en Buenos Aires, Editorial Claridad, 1945. En esta edición 67-233. Confiesa que fue escrito entre febrero y marzo de 1937,71 . 
La minería cayó del mismo lado casi en su totalidad. En sus manos estaban los mejores carbones de Asturias, Peñarroya y Puertollano, los lignitos en la Cordillera Ibérica. Lo mismo sucedió con el plomo, en La Carolina y Linares, Aznaga y Mestanza y Mazarrón, y en Almadén con su riqueza en mercurio, en Hellín, con los azufres, en Castellón con los esquistos y en Cataluña con los abonos minerales.

De lado del "gobierno andariego" quedaron las huertas de Valencia y Murcia y otras zonas de riqueza agrícola como Almería, Cataluña, La Mancha, y la riqueza oleícola de Jaén. Quedó igualmente el corcho, desde Extremadura a Gerona.

En la industria, la superioridad fue "abrumadora". La siderurgia en Bilbao y sus prolongaciones hacia Santander, Asturias y Sagunto. La industria textil en Cataluña, Valencia...

Salvo Sevilla y Zaragoza, en su poder quedaron las grandes ciudades, las comunicaciones, los nudos ferroviarios importantes. De las 19 provincias costeras, solo cayeron 4 del lado de Franco, que no tenía frontera más que con Portugal.

¿Cómo se pudo malograr esta enorme ventaja inicial? No lo fue por reveses militares que supusieran pérdidas territoriales. Lo importante fue el descuido y el desprecio de las leyes que rigen la economía. Faltó orden y transparencia en la gestión de la administración y en la contabilidad. Hubo caos y prodigalidad desenfrenada.

Un ejemplo: las "legiones de diplomacia pictórica e improvisada y consulados inverosímiles, a modo de regimientos; las legaciones superfluas con volumen de unidades orgánicas, costosas embajadas en pie de guerra. Se han costeado ofensivas de imprenta a todo lujo, más caras que las de la artillería, y con la sola eficacia de propagar la ficción del éxito imaginario.

Cada compra ha recibido el encarecimiento progresivo, acumulado de comisiones de readquisición que, de paso, acercaron a lujos nunca soñados y hallaron esparcimiento en las metrópolis del placer o en los recreos del juego".

Los establecimientos de crédito se transformaron "en lugares de descrédito". Lo mismo pasó con el Banco de Emisión, al que se quitó sus reservas. Cuando se despojó a los propietarios se paró el impulsó para construir y cultivar. Se creyó que distribuir incrementaba el consumo, pero este no asegura una distribución eficaz, porque "no reparte, sino esparce".

El trabajo no resiste convivir con el delito. El pueblo quedó pobre, sin enriquecerse los que asaltaron la riqueza. El saqueo no es otra cosa sino un brutal parasitismo.

Nada de esto sucedió en la "zona dictatorial". Su economía austera, fue a la vez sólida y resistente. Siendo primitiva, aseguró el sustento y el autoabastecimiento. Se adecuó mejor a la situación de guerra. ${ }^{181}$

\section{UN HOMBRE BUENO ANTE LA GUERRA}

181 Alcalá Zamora, N. 2003. “Armas económicas: lo inexplicable” y "Las Armas económicas: la explicación”, La Nación, 24 junio y 14 julio 1938, “Artículos publicados en el diario "La Nación” (Buenos Aires, 1936-1939), 169-175. 
El 7 de julio de 1936, desde el puerto de Santander, Alcalá Zamora embarcaba para el norte de Europa. Ha contado que hubo una especie de premonición en ese viaje imprevisto e impensable en él que esperaba llegar al fin de su mandato constitucional e iniciar una nueva etapa el domingo 12 de diciembre de 1937.

El 18 de julio estaba con su familia en Islandia. Buscó luego asilo político en Francia. Sobrevivió escribiendo en la prensa y gracias a que era abogado de un banco francés. No quiso disponer de fondos, por motivos patrióticos. Dada la debilidad de la peseta, había ordenado que los transfirieran a sus cuentas corrientes en bancos de Madrid.

Este liberal no eludió su deber. En las dos series de artículos, para La Nación, de Buenos Aires, y para L'Ére Nouvelle, de París, se contempla su tensión ética, su amor a España, su solidaridad apasionada con la República, su sufrimiento por mantenerse libre de los peligros que, desde dentro, amenazaban su futuro... ${ }^{182}$

Fue esa una de las claves de su conducta en todos los momentos, incluso en el más dramático, el de abril de 1936. Entonces, ante el peligro de la guerra civil, supo cumplir su deber, a expensas de su interés personal. ${ }^{183}$ Cuando tiene noticia de la guerra civil y de los primeros excesos, escribe Alcalá Zamora:

"Dos consideraciones contrapuestas alternaban en mi reflexión: lo inconcebible del rápido hundimiento de una República que nació tan fuerte y aclamada; lo explicable de ello ante la enormidad de los errores, de las culpas incesantes, que culminaban en crímenes y que, en rigor, solo habían encontrado el obstáculo insuficiente de una buena voluntad, apartada la cual por la violencia que me derribara, esta llevó, en solo unos días, al desastre total". ${ }^{184}$

Cada bando había llegado a la guerra civil, desoyendo advertencias, "temiendo su aplastamiento y procurando el del enemigo". Por eso, una vez iniciada, "no querrán fácilmente exponerse a sufrirlo o a dejar de lograrlo".

En España podía aún contarse con las tendencias que, en los partidos, pudieran ser eficaces consejeros y que, avisando de la amenaza de sufrir un exterminio, "refrene a la crueldad de imponerlo".

${ }^{182}$ Se trata de artículos fueron escritos por "un demócrata progresista, un hombre justo, bueno, en el sentido machadiano... Sirvieron como cargo en el Tribunal regional de Responsabilidades Políticas de Madrid. Lo condenaron el 28 de abril de 1941 a una multa de 50 millones de pesetas, a la consiguiente incautación de todo su patrimonio. Le quitaron la nacionalidad española. Se le acusó de haber difamado en sus escritos al "Glorioso Movimiento Nacional". Alcalá-Zamora, J. 2000. "Brevísimo prólogo a un libro importante", 9 febrero 2000, "Confesiones de un demócrata", IX-XIII.

183 Siguiendo su labor como diputado en las Cortes constituyentes, no presentó su dimisión, porque lo juzgó el único medio a su alcance para moderar una Cámara que "tendía hacia la demagogia" en la aquella legislatura. En 1936. En la primavera de 1936, deseaba dimitir, pero no lo hizo, porque no era el momento. El Frente Popular creyó que, con Azaña en la presidencia de la República, todos los poderes quedaban bajo su control. De ese modo creyeron evitar el riesgo de una nueva oscilación en el año y medio que restaba hasta diciembre. "Por qué no presenté la dimisión" y "Por qué no resistí", Ibídem 12 y 21 enero 1937, 13-16 y 20

184 Alcalá Zamora, N. 1976. 380. España agosto de 1936 estuvo Alcalá Zamora con el presidente Édouard Herriot. Al negar el indulto a los generales Manuel Goded Llopis y Joaquín Fanjul Goñi, comentó a Alcalá Zamora, el Gobierno daba un "peligroso sello oficial a la ferocidad con que había estallado la guerra civil”, Ibídem 413. 
Quedaban intelectuales, artistas, gentes de prestigio moral que, sin ser exclusivistas, puedan condenar los horrores "que destruyen a un gran pueblo y afrentan a toda una civilización".

$\mathrm{Al}$ concluir el elenco de posibles intervenciones para llegar a la paz, recuerda Alcalá Zamora, que un factor importante es "la esperanza nublada, pero no extinta... en esa maravillosa clarividencia, que, en sus horas críticas, salva a España, a veces rodando ya por el abismo. ${ }^{185}$

La revolución rusa fue un aviso de lo que sería una guerra social, "la española lo ha confirmado". ${ }^{186}$ A esta tesis de la Guerra Civil como guerra social y no religiosa se acogieron los nacionalistas vascos. Fue su argumento para defender su posición frente a las presiones de la Santa Sede ante las elecciones de febrero y para aliarse con la República, cuando el golpe fracasó y se inició la guerra. ${ }^{187}$

Los vascos fueron los "aliados inverosímiles" del Frente Popular. Telesforo Monzón contó a Alcalá Zamora que dudaron bastante, sobre todo tras la pastoral de Mateo Múgica y de Marcelino Olaechea. El hermano del obispo de Vitoria les aconsejó que convocaran una junta de arciprestes. Casi por unanimidad se decidió en ella que era preferible seguir con el Gobierno republicano. "Es quizás algo de lo más curioso que hay en los prólogos y orígenes de esta Guerra Civil”. ${ }^{188}$

El 1 de septiembre, Alcalá Zamora denunció el espectáculo de los fusilamientos en masa, de las víctimas inmoladas, tomadas entre los rehenes o, a veces, por mera fatalidad. Ese ocaso de la moral afrenta y es una negación de la civilización. Se había perdido el respeto a la vida. Quien no respeta este carácter sagrado e intangible de la vida humana, prepara una "implacable venganza"

"No hay necesidad ni siquiera conveniencia bélica que, aun de todo [lo que siendo] parcial y pasajero, fundamente la ferocidad. Si de rendirse a resistir hasta la desesperación no hay diferencia de trato para los vencidos, la victoria será más cara, difícil y, a veces, perdida, porque la certeza de morir entregando las armas y la esperanza de defender con ellas la vida, hará de la desesperación el manantial del heroísmo".

En febrero de 1937 ponían las autoridades de Madrid dificultades a la evacuación de los que deseaban salir y de los "asilados" en las embajadas. Desde el punto de vista jurídico y humanitario, debería darse prioridad a que salieran de la ciudad todos los que lo desearan. Eso tranquilizaría a los que decidieran permanecer en ella.

Urgía porque había el peligro de que se eligiera para ello a "enemigos políticos y sociales y que "un viaje de rehenes o de prisioneros, incluso a corta distancia, es desviado a menudo por extraños caminos hacia el viaje eterno". No puede convertirse la evacuación en una "espantosa tragedia". Lo sería si esta se inicia con los enemigos de las autoridades.

185 Alcalá Zamora, N. 2003. "Situación actual de España” La Nación, omitida la fecha en esta edición, pero antes del 24 agosto 1936, “Artículos publicados en el diario "La Nación” (Buenos Aires, 1936-1939), 6973.

186 Alcalá Zamora, N. 2003. "La revolución rusa anunció lo que sería una guerra civil de carácter social, la española lo ha confirmado", La Nación, omitida la fecha en esta edición, pero antes de octubre 1936, “Artículos publicados en el diario "La Nación” (Buenos Aires, 1936-1939), 91-95.

${ }^{187}$ Vid el trabajo que en este mismo número publica Miguel Ángel Dionisio

${ }^{188}$ Alcalá Zamora, N. 1977. 420-421. 
Hay un imperativo político: quienes afirman luchar por la libertad deben respetarla. Si se asegura tener el apoyo de la opinión, nada debe temerse de que esta se exprese. No cabe la excusa de que algunos de los evacuados puedan ser combatientes contra la República. Los que podrían serlo fueron movilizados ya o están encarcelados.

Interesa a los directores de la evacuación que se haga de modo voluntario y libre toda sospecha. Las "operaciones de limpieza", que endosan a la situación de guerra civil y atribuyen a gente anónima, que no se puede controlar, no ocultan el hecho de que son gente armada y utilizada por las autoridades. ${ }^{189}$

La violencia hasta el exterminio multiplica la resistencia de quienes saben qué suerte les cabe si se entregan al enemigo.

Del derecho no se puede prescindir ni siquiera en las guerras civiles. Todo lo que se lee y oye, “es monstruoso y criminal". Es especialmente grave el fusilar a los prisioneros y la guerra sin cuartel... Quienes luchan en estas condiciones, con sus terribles consecuencias y con tan escasa libertad...han de rechazar esa ferocidad y los actos condenados en el derecho de gentes.

El caso de los rehenes es aun más grave. Porque estos no eligieron sufrir el riesgo de la guerra, sino sustraerse a la violencia. A ninguno de los dos bandos aportan valor militar. Son gentes de profesiones apartadas de la milicia. Ni tienen deseos de combatir ni han cometido crímenes de guerra.

Esos actos contra todo derecho alimentan la combatividad del adversario y merecen la condena del mundo, que se horroriza de ellos. Urge una sacudida de la conciencia de quienes luchan y de los que presencian esos sucesos. ${ }^{190}$

Las guerras civiles no impulsan la paz ni la convivencia. Han sido y son acicate de la crueldad, del odio, del destierro, cuando no de la muerte de todo freno moral, de todo respeto, de toda posibilidad de convivencia. La vida, también la propia, se devalúa.

Generan además otros efectos, entre ellos, el crecimiento del militarismo. Esto es especialmente peligroso, porque, a diferencia de la guerra entre naciones, las civiles mantiene vivo el deseo de desquite. Conservan el incentivo del odio.

"Tras una guerra por ideología, la convivencia, sentimentalmente imposible y materialmente inevitable, de los que fueron enemigos y de sus conminadores, de los que se creen víctimas y se llaman verdugos recíprocamente..."

Todo eso hace la pacificación muy lejana y casi imposible. Se necesitan generaciones para recuperar la coexistencia. Se eleva en la guerra civil el límite de tolerancia para la licitud de la ferocidad, de los excesos, de la destrucción. Además de esos malos hábitos y de esas situaciones emocionales, crea intereses: pensiones, derechos preferenciales, indemnizaciones, reclamaciones... en todos aquellos a quienes la guerra otorga "un título sangriento" a sus demandas.

189 Alcalá Zamora, N. 2000. "La evacuación de los no combatientes”, L’Ére Nouvelle, 6 febrero 1937, "Confesiones de un demócrata", 21-23.

${ }^{190}$ Alcalá Zamora, N. 2003. "Horrores y crímenes: fusilamientos y rehenes" La Nación, 1 septiembre 1936, “Artículos publicados en el diario “La Nación” (Buenos Aires, 1936-1939), 75-78. 
Cuando todo eso se asome a la guerra exterior, ¿quedará algo del ideal pacifista recogido en la Constitución de 1931 ?

La magnitud de los horrores de la guerra civil de 1936 supera todas las anteriores. El país parece haberse convertido en un gigantesco frente. Eso aumenta las dimensiones de su fiereza y su "crueldad más refinadamente inicua". Parece que se proclama un "el retorno sin disfraz a la barbarie".

La delincuencia política se disimula como "operaciones de retaguardia". Estas son un catálogo de robos y asesinatos. Ahora los delitos son "lucrativos". Las guerras actuales no admiten zonas abiertas, exentas. Todos son beligerantes, "sin excepciones de piedad". El derecho internacional se ha hundido. En las guerras civiles, quien no "está afiliado" es enemigo, incluido el extranjero.

"Vivimos y sobre todo convivimos y merecemos vivir, gracias a los valores, a la fuerzas morales; y cuando se relajan, no ya cuando se niegan, el retroceso se paga hundiéndose todo en el abismo de la violencia y la barbarie...Este cuadro de valores morales invertidos y despreciado, con los dolores trágicos que ello hace sufrir a la humanidad, no puede significar la esperanza en el nacimiento de otra civilización mejor; al contrario, amenaza, como agonía de una espléndida cultura que se hunde". ${ }^{191}$

\section{"SOY Y SERÉ REPUBLICANO Y DEMÓCRATA"192}

Al iniciar su estudio sobre la Guerra Civil ante el derecho internacional esperaba que se produjera una reacción ante "tan brutal retorno a la desaforada violencia". Creía que habría un resurgimiento del derecho, "con una ordenación más justa, estable, biológica". Vendría luego su conservación y sus renovaciones, para "encauzar la paz, quitando esta a la guerra su razón de ser: la remoción del quietismo poseedor en lo que tiene de inicuo, de anacrónico y de obstinado". ${ }^{193}$

Hay una crisis de la democracia. En ella actúan dos factores: la tensión internacional y las injusticia sociales. Estas deben superarse "por la prudente vía de las transformaciones legales". Sin despejar estas dos amenazas, seguirán hundiéndose las democracias y no se restaurarán donde acaban de desaparecer. La República española, nacida con tantos elementos favorables y esperanzas, "no conserva ya más que su nombre", pues "se desvanece, embarcada en una lucha entre una dictadura de izquierdas y una dictadura de derechas".

191 Alcalá Zamora, N. 2003. "Las guerras por ideología y el pacifismo absoluto" y "La codicia en los delitos políticos", La Nación, 5 diciembre 1936 y 26 enero 1937, “Artículos publicados en el diario "La Nación” (Buenos Aires, 1936-1939), 110-112 y 117-120. Sobre el país convertido en un inmenso frente, "Plazas abiertas", La Nación, 2 marzo 1937, Ibídem 122-123 y "El destino de la población civil”, L'Ére Nouvelle, 4 octobre 1936, "Confesiones de un demócrata", Obra Completa... 2000, 69-70.

192 “....soy y seré un hombre que lleva en sí, que siente y practica todos los postulados de la democracia política dentro de las convicciones más firmes de su espíritu” “...soy partidario decidido de la justicia social más amplia y completo por lo que solo pido, incluso ante sus estructuras, una mayor audacia, el respeto por las posibilidades económicas del momento" para evitar una ruina. Alcalá Zamora, N. 2000. "Prefacio de una colaboración o confesión de un demócrata", L’Ére Nouvelle, 24 noviembre 1936, "Confesiones de un demócrata", 3-5 y 13-14.

${ }^{193}$ Alcalá Zamora, N. 2000. "La Guerra Civil ante el Derecho Internacional”, febrero 1937, 4 y 63. 
El deber de las democracias, que aún subsisten, es "salvarse a sí mismas y ayudar así a la resurrección de otras, que volverán a nacer sin los errores de antaño, y agrupadas en una humanidad más pacífica y más justa". ${ }^{194}$

La crisis del parlamentarismo y la reflexión sobre ella eran preocupaciones generales. Fue una crisis rápida y sorprendente. Acabó con las ilusiones. La democracia pervivía en el Reino Unido y en algunos países del noroeste de Europa.

El mayor peligro para este sistema es sus propias debilidades. Se ha quedado sin las fuerzas que fueron su soporte. Las debilidades las explotan a su favor quienes se benefician de ellas. Un sistema político muere por "suicidio". Por eso Alcalá Zamora cree que debe reforzarse la acción del Gobierno, reducir en los parlamentos la intensidad y extensión de la obra legislativa y de control, de modo que los gobiernos no sean en sus manos un juguete de recambio.

Urge también corregir que primen los intereses de los elegidos y de los partidos sobre los del país...Todos estos hechos, estas evidencias, conocidas, parecen estar olvidadas. Eso ha costado "desgraciadamente la muerte de las libertades que nos eran tan queridas". ${ }^{195}$

El siglo XX estaba siendo el del ascenso de los totalitarismos. Esta situación, ¡diferente del absolutismo monárquico, era peor para la libertad ${ }^{196}$

El comunismo repele a quienes creen en la democracia y en la igualdad social. Asusta a la reacción. Llevó a España hasta la Guerra Civil. Ha heredado a las dictaduras totalitarias, voluntariamente o por obstinación, pero casi legítimo por su parecido con ellas. El comunismo es una dictadura en lo político y un totalitarismo en lo social.

Era partidario Alcalá Zamora de reducir las dimensiones del Estado, en lugar de ampliarlas. Esto era una condición para regresar a "una serena capacidad de convivencia", tras una guerra, "la más cruel y sanguinaria que el mundo ha conocido". Nadie debe avivar en España el recuerdo de la venganza, ni proseguir las agresiones a los del otro bando. No debe ofrecerse a España la perspectiva del "infierno permanente del odio y de la violencia". Las derechas conservadoras no deben caer en la tentación de la

194 Alcalá Zamora, N. 2000. "La situación internacional y la crisis de las democracias”, L'Ére Nouvelle, 4 diciembre 1936, "Confesiones de un demócrata", 6-7. La guerra civil era una lucha entre dos dictaduras, "Todo régimen político perece por suicidio", diciembre 1936, Ibídem 12. La izquierda es totalitaria, "Por qué no resistí", 21 enero 1937, Ibídem 19.

195 Alcalá Zamora, N. 2000. "La crisis del parlamentarismo”, L’Ére Nouvelle, 23 abril 1939, "Confesiones de un demócrata", 164-166.

196، No podemos comparar la tiranía de Estados dictatoriales modernos con la de las monarquías absolutas del antiguo régimen, porque, bajo aquellas, la inhibición del Estado en varios órdenes de la vida, el aislamiento social e incluso territorial de los pueblos hacia la autoridad. Todo eso creaba unas situaciones de realidad sin coacciones que eran, en cierta medida, unos refugios donde no se usurpaba la libertad personal, de tolerancias prácticas, sustitutivas de las libertades políticas, entonces solamente concedidas o denegadas en principio". Alcalá Zamora, N. 2000. "Hay que coexistir para poder existir", L’Ére Nouvelle, 25 febrero 1937, "Confesiones de un demócrata", 25. 
Dictadura, porque el final de esta es el caos social, pues se engañan pensando que se les otorga un "privilegio explotador". 197

"La Guerra Civil, como crimen máximo en los pueblos, excluye por esencia y en realidad todo intento de norma jurídica que le sea aplicable". Más bien acumula todos los delitos previstos en la Códigos Penales. Pisotea todos los principios del Derecho Público. Nada de él queda en pie. Anula la Constitución. Destruye los procedimientos judiciales. Invierte totalmente las dos nociones básicas de la pena. Cada bando, deseando eliminar al otro, impone como pena lo que no es más que un crimen ejecutado por los suyos.

El reconocimiento de los "Gobiernos" de cada bando en una Guerra Civil ni debe ser arbitrario ni da legitimidad. Se basa en la situación real y busca no complicar el conflicto. Se impone un reconocimiento de facto cuando se estabiliza la situación bélica y política. El de jure debe hacerse cuando esté claro el vencedor y la victoria sea una cuestión de plazo, de corto plazo.

Aplicando al caso de España, este fundamento se produce cuando "la resistencia al "Gobierno" triunfante ha desaparecido o está limitada a una obstinación andariega, estrechamente localizada o de perturbación endémica". En ese caso, el "reconocimiento no puede aplazarse".

Con ese acto se adquiere la obligación "más imperiosa, estricta y exigible de hacer civil la guerra, ateniéndose a las normas universales y humanitarias del Derecho de Gentes. Por este motivo no es conveniente retardar esa decisión por motivos egoístas o de mala fe. En el caso de España se produjo este aplazamiento entre quienes deseaban prolongar la guerra, porque buscaban una "intervención dosificada". ${ }^{198}$

Nunca ha habido una intervención extranjera tan amplia y decisiva en una contienda civil. En España "se grita para matar en todos los idiomas". A eso se suma que el material bélico es importado casi en su totalidad. España ha sido campo de experimentación de nuevas armas y explosivos y hasta una oportunidad "para enviar a luchar y a morir a los extranjeros peligrosos, indeseables o simplemente parados en su país".

La intervención es la responsable de la duración de la guerra, que ¡ha permitido sus brutales excesos y la gran mortandad, acrecentada con los crímenes en la retaguardia.

Hay un cinismo horrendo y frío. Tras conocerse esos hechos, los socios y protectores de cada bando deberían haber avisado que suspenderían su ayuda "si no se atajaba la criminalidad". Habían preferido creer que se puede ayudar a quien delinque sin contaminarse con su culpa.

El Comité de No intervención debió llamarse "de Intervención Compensada, reglamentada, dosificada". Lo sucedido, y tiene su mérito y debe reconocerse, es que los pueblos sensatos "han sabido salvarse, limitando la desolación de la guerra a la enloquecida España, de sobra castigada por su demencia".

197 Alcalá Zamora, N. 2000. "Régimen político de convivencia en España, 1945, 99-101. Apareció en Buenos Aires, Editorial Claridad, 1945. En esta edición 67-233. Confiesa que fue escrito entre febrero y marzo de 1937, 71.

${ }^{198}$ Alcalá Zamora, N. 2000. “La Guerra Civil ante el Derecho Internacional”, febrero 1937, 44-45 y 4950. 
Podría ir terminando la guerra si se siguiera con medidas como vigilancia de costas y, si el oro arrebatado al Banco de España, "mediante la más audaz y enorme confiscación, se va agotando", porque eso sería decisivo para detener los suministros militares. "La guerra de España va dejando de ser negocio lucrativo para convertirse en peligroso". ${ }^{199}$

Hay cuatro aspectos que explican el apego de las democracias al principio de no intervención: la independencia y soberanía de las naciones, los recuerdos históricos de las intervenciones, el mantener la cohesión interna que hace viable una sociedad plural y, finalmente, porque la intervención de país en otro agrava los problemas de justicia social. El combatiente arrostra todos los problemas sin tener la dignidad de ser un soldado que defiende a su patria.

Hay una forma de intervención discreta, disimulada, que podría ser calificada de maquiavélica, si fuera sabia y tuviera éxito, y más viable en dictaduras. El mismo Maquiavelo dice que este tipo de intervención fracasa. Sirve para prolongar la discordia y dejar abierta la reanudación de la lucha. Lo más que puede esperarse es que la neutralidad se torne en benevolencia para "acordar medidas que atenúen los horrores. ${ }^{200}$

La Guerra Civil en España ha mostrado la violación sistemática y constante, hipócrita y cínica, de las normas jurídicas, incluso por parte de las grandes potencias. Han hecho lo contrario de lo que debía esperarse de ellas. Han cometido una transgresión, sin eximentes, del derecho internacional. Han abierto la puerta para que, en otras guerras civiles vuelvan, a repetirse, agravados, los mismos errores y violaciones del derecho.

En resumen, la intervención es un abuso y la neutralidad, un deber. La intervención es el crimen máximo porque a una guerra interna suma la guerra extranjera. La Guerra Civil española pudo concluir en otoño de 1936. No lo fue porque la intervención extranjera impidió la caída de Madrid. En 1938, "la sorprendente y prolongada Batalla del Ebro" no contaba con medios ni correspondía a los fines del Gobierno de Juan Negrín. Se pensó para enlazar la guerra de España con la guerra mundial. No fue así, porque en Munich se evitó esta. La ofensiva "fulminante de los nacionales en Cataluña", entre diciembre de 1938 y febrero de 1939, quería controlar toda la frontera con Francia, una vez que Mussolini manifestó su voluntad de reclamar Túnez y Córcega. Tras lo de Etiopía, eso significaba una guerra con Francia. En 1936 también, Alemania inició la militarización de Renania.

La neutralidad es un deber, no un derecho. Siendo las luchas internas ajenas a la soberanía de otros Estados, sus derechos son inferiores a los que posee el país en guerra civil. Hacia este, los otros no tienen derechos, sino deberes. Su neutralidad es el primero de todos.

En la Guerra Civil se manifiestan cuatro elementos: tiempo, espacio, fuerza y orden. El primero, significa duración sostenida. El espacio significa que no hay gran diferencia en el reparto del territorio. La fuerza es 1 capacidad militar, y el orden, la existencia de un sistema de gobierno. Con todo eso, debe analizarse si este equilibrio hace incierto el desenlace.

199 Alcalá Zamora, N. 2003. “Artificios internacionales de la no intervención”, e "Intervenciones apasionadas e intervenciones agotadoras" La Nación, 6 junio 1937 y 10 octubre 1938, “Artículos publicados en el diario "La Nación” (Buenos Aires, 1936-1939), 129-132 y 185-187.

200 Alcalá Zamora, N. 2000. "Democracia y no intervención”, “Maquiavelismo y no intervención” y “Maquiavelismo y no intervención (2)", L'Ére Nouvelle, 22 julio y 14 y 21 de agosto 1937, "Confesiones de un demócrata", 54-60. 
La neutralidad obliga a no apresurarse, a no "madrugar" para primar a uno de los contendientes, ni retardarse, por ojeriza a uno de ellos. Esta última postura, la juzga Alcalá Zamora como la más injusta.

Hay otro aspecto, los partidos de gobierno tienen el deber de neutralidad en caso de una guerra exterior. "Cuando uno solo de los partidos combatientes realice el abominable exceso de asociarse a una guerra exterior, será traidor el nacional que, sin seguir entonces las banderas de su patria, voluntariamente, se aliste, bajo las extrañas para luchar así contra una facción de las suyas". ${ }^{201}$

Los países neutrales tienen el derecho de impedir la entrada en su territorio y el de expulsar de él. Pero en caso de Guerra Civil, tiene el deber de "no convertirse en instrumento de la pasión furiosamente persecutoria" de los bandos enfrentados. No deben entregar víctimas a la venganza de sus odios.

Los refugios abiertos por las embajadas son "islotes de civilización y de piedad" entre los horrores de la Guerra Civil. Deben ser un amparo completo, que se extienda a los consulados. Ese derecho de asilo es inviolable. Debe respetarse, cuando, rotas las relaciones, se encomiende la tutela de los intereses del país a un tercero.

Sean cuales fueren los problemas, es absolutamente rechazable cooperar a una posible persecución por motivos políticos. ${ }^{202}$ Analizados los diversos aspectos jurídicos, debe tenerse en cuenta que los problemas se agravan "por la duplicidad o por la injusticia persecutoria de la legislación" promulgada durante la guerra. Los tribunales de otro Estado deben conocer las abominaciones que pueden cometerse y han de refrenarlas.

No pueden actuar como verdugo de la crueldad extraña, copiando o traduciendo resoluciones de tribunales, que emiten con frecuencia fallos monstruosos y avalan venganzas y crueldades. Estas, bajo el sometimiento a un poder sin control, a la pasión política, dando valor retroactivo a sus decisiones y procediendo a la medida de los intereses y de cada caso, son ilegales. Les faltan condiciones para serlo, porque niegan al adversario todo derecho e impiden que pueda ejercer el de su defensa.

En el caso de España ¿cómo puede acabar la Guerra Civil? Lo examinó. Algunos modos dañan o desconocen la soberanía nacional. Eso sucede con la mediación y el arbitraje. La mediación puede ser "coactiva e interesada". La buena voluntad de otros países no debe traspasar el límite de "buenos oficios". La propuesta de una "fórmula de paz" es casi siempre una conducta parcial. En el caso de España, las propuestas pueden venir de dictaduras, de un régimen comunista, de grupos monárquicos.

Debe descartarse el recurso a un plebiscito pues, en una guerra civil, faltan las condiciones para que sea libre y sus resultados sean respetados. La guerra civil hace que los votos no se agrupen, sino que se contrapongan. Hechos bajo control de los combatientes, son una farsa. La tutela internacional, en forma de ocupación, es una solución que nada arregla y casi siempre agrava. Las fuerzas de ocupación deberían ser internacionales.

${ }^{201}$ Alcalá Zamora, N. 2000. “La Guerra Civil ante el Derecho Internacional”, febrero 1937, 5-7, 13-118 y 53. Sobre las formas de ayuda a los beligerantes y su legalidad, Ibídem 18-30.

202 Alcalá Zamora, 2000. "La Guerra Civil ante el Derecho Internacional”, febrero 1937, 31 y 48. 

buena fe. ${ }^{203}$

El mejor medio es un acuerdo entre los combatientes, con la ayuda de Estados que actúen de

En la cuenta de resultados del conflicto, recuerda Alcalá Zamora, que esta es la cuarta guerra civil y la primera que gana "el carlismo", es decir todo lo que se opone a la libertad y al progreso de España. En el origen inmediato de este resultado está la magnitud del extremismo demagógico en los meses posteriores a febrero de $1936 .{ }^{204}$

España, experta en guerras civiles, con la espalda vuelta a la historia, desconoce que las guerras acaban con victoria, "por desnivel de éxito militar". No cabe el recurso a un plebiscito ahora, porque "cada elector, movido por el terror, el odio o la venganza, votaría eligiendo no el bien del país, y sí su papel de verdugo o víctima". No lo aconseja el hecho de que, "borradas entre horrores tales la sensibilidad moral y la actitud cívica, así como la libertad necesaria, aparece de momento eclipsada, aun para ejercicio menos trascendental de su albedrío, la capacidad jurídica del electorado hispano". ${ }^{205}$

Ninguna sociedad, ni siquiera una enteramente nueva, puede construirse desde la ruina. ¿Era el momento de la paz? Había que pensar en ello y tomar decisiones sin retraso. Los beligerantes no tienen fácil iniciar las gestiones para la paz. No pueden hablar de ella a los ciudadanos, sometidos al terror. Deberían hacerlo los españoles exiliados.

Los extranjeros generosos y conscientes no deben consentir el suicidio de un país por proteger la causa con la que se simpatiza.

"He sentido tantas amarguras, injurias, queriendo evitar a mi país los horrores de la guerra civil, que no podría extrañarme de las nuevas injusticia que voy a atraer sobre mi del lado del fanatismo rencoroso. Pero trabajando por la paz de mi patria, empiezo a asegurar la de mi conciencia. Si, según mi opinión, la paz es un deber, yo debo asumir el mío y quiero cumplir con él". 206

Incluso los que creen en una solución autoritaria, deben imponerse como debe patriótico impedir una nueva guerra civil, consolidar la paz, fortalecer el Estado y el Gobierno, reducir al mínimo, por procedimiento lícitos, todo lo que cree inquietud entre los ciudadanos y miedo en la oposición. No debe suscitarse el debate sobre el régimen, sino aceptar la República, porque en España "tienen más facilidad y fuerza para mostrarse eficaz, mantener el orden e imponer respeto a la ley". La monarquía funcionó, incluso en su versión democrática, con "adulteraciones sistemáticas". Necesitaría un Sagasta y un Cánovas y los hombres que los rodearon para hacer compatible la claridad del proyecto político conciliador con las maniobras electoreras.

203 ibídem 37-41 y 59-64.

204 Alcalá Zamora, N. "Régimen político de convivencia en España, 1945, Obra Completa... 2000, 139-140. Apareció en Buenos Aires, Editorial Claridad, 1945. En esta edición 67-233.

205 Alcalá Zamora, N. 2003. "Pacifismo extraviado", La Nación, 19 noviembre 1937, "Artículos publicados en el diario “La Nación” (Buenos Aires, 1936-1939), 139-140.

206 Alcalá Zamora, N. “La paz es un deber”, L’Ére Nouvelle, 14 y 15 julio 1937, “Confesiones de un demócrata", Ibídem 51-53. 
La España de la posguerra no podrá resistir esa farsa. No podrá sangrase con meras ficciones ni con elecciones fraudulentas. España no debe redimirse de su desgracia cometiendo vilezas, de las que debería avergonzarse.

Para los vencedores mantener la República daría credibilidad a su tesis de que el alzamiento iba contra los errores, claudicaciones y excesos, y contra la falta o la pérdida de legitimidad de quienes ejercían el poder. Esto permitió a los sublevados la adhesión de las guarniciones que se les sumaron tras los sucesos de julio y de los militares que se negaron a combatir contra ellos. Se explica así el que los dirigentes del alzamiento se opusieron a que el pretendiente de la corona pisase el territorio controlado por ellos.

Desde el punto de vista internacional, hay que librarse de hipotecas contrarias al interés de España.

Las dictaduras tienen un dinamismo antimonárquico. Si se prolonga, arruina la democracia, esencia de la República. Por eso en esa hora, hay que recurrir a la decisión manifestada abrumadoramente por los españoles, legal y pacíficamente, en abril de 1931: que España sea una República. Por eso el problema del régimen estaba "definitivamente resuelto". Hay que ir a una legalidad constitucional, que rectifique la que ha sido destruida y que "desembocó en la guerra civil". La Constitución de la República Española estaba "herida desde las vísperas de la misma, murió en ella". 207

\section{PAZ INTERNA Y CONCORDIA NACIONAL}

Fue anotando para el recuerdo y para dar razón de su conducta el material de lo que pensaba que fueran sus Memorias. Todo esto desapareció. Fueron secuestrados estos papeles en julio de 1936 los documentos con los que pensaba escribirlas, violando la caja fuerte en que estaban guardadas junto con otros documentos. Alcalá Zamora sostiene que se hizo con la complicidad de los Gobiernos presididos por José Giral, Francisco Largo Caballero y Juan Negrín.

Entre el 8 de marzo al 8 de junio de 1940 las redactó en Pau. Se le añadió posteriormente unos apéndices. Se propuso facilitar al lector la comprensión de hechos que le afectaron y de los que puede ofrecer una "versión o interpretación singulares de algún interés". ${ }^{208}$

La España de 1940 no debe pensar en aventuras imperiales y menos si eso supone perder su independencia. Nada de guerras externas sin paz interna. No a las quimeras expansivas, si está destruida la concordia nacional y se ahondan los odios y violencias. Se necesitaba una Hacienda austera, que no devore la economía arruinada. Pesan sobre España los millones de pesetas desvalijadas, que son como "una pesadilla entre insomnio y vigilias".

La Guerra Civil ha hecho estrago en todas las costumbres, que marcaban el campo de lo lícito en el terreno económico, y en la decencia con la que debe cada cual conseguir y conservar sus bienes.

${ }^{207}$ Alcalá Zamora, N. "Régimen político de convivencia en España, 1945, Ibídem 75-80.

${ }^{208}$ Alcalá Zamora, N. 1976 13-17 y 57. 
Ha sido horrible el número de asesinados, condenados sin proceso, destruyendo la existencia misma de una justicia independiente, igual para todos. A la guerra ha seguido una situación donde unos continúan cometiendo esos crímenes y otros sueñan con hacerlo en cuanto puedan.

Esto no se remedia con la fuerza. Sólo puede serlo con la cultura. Con ella, situándose cada uno ante su deber y saliendo de la indisciplina, de la iniquidad, de la dejadez de sus funciones, mirando al interés nacional, podrá retornar la paz civil y será duradera.

Desde el 10 de noviembre de 1940, que llegó a Marsella hasta desembarcar en Buenos Aires el 28 de enero de 1942, pasaron 441 días. Desde este día solo quiso "sostener el decoro de la vida, entendiendo que aquel está ante todo en la diafanidad de la conducta y en la paz de la conciencia, más que en el bienestar material formado a nuestro alrededor". Será "un emigrante más, un trabajador, que quiere ser útil a todos y gravoso a nadie". ${ }^{209}$

Era uno más de los que la Guerra Civil “expulsó fuera de España”. Estaba pasando por América simultánea y sucesivamente, quizás los más valioso y selecto de ella. Esos españoles, que han venido a sufrir, "han prestado inmenso servicio". Estaba forjándose un sentimiento nuevo de ser españoles. Quienes se marcharon no quisieron estar bajo el sometimiento. Prefirieron la expatriación, "para no ser cómplices ni víctimas de la violencia ni del atropello".

Quiso ir a América siendo presidente de la República. No fue posible. "Llegué en un barco de carga, cuando no como pasajero de tercera, recibido en el muelle por muy pocos amigos". Quiso dejar constancia de que no le deshonraba haber representado a España desde la pobreza, "porque no ha sido en la vileza, en la fastuosidad, porque ha sido con dignidad en la decadencia" de su organismo y sobre todo, "porque no ha habido la apostasía suicida de mi nobleza moral" 210

Cuando el 31 de octubre de 1941, pudo embarcar en el Quanza, un barco portugués, en el puerto de Casablanca fue aplaudido por los otros exiliados españoles. Entendió que era un reconocimiento de que había acertado al oponerse a cada uno de los dos bandos que ensangrentaron España. Al elegir eso, su destino era "ser víctima" del vencedor.

Como liberal, comprendía la resistencia de quienes se equivocan a reconocer el error, pues "la duda de un remordimiento precede a la meditación de un arrepentimiento" y "antes se siente el mal que se ha hecho que se confiesa el error cometido".

El deber conduce siempre a la compasión. ${ }^{211}$ Esta debe poner en primer plano la tutela de quienes necesitan el amparo de la justicia. No la había habido durante meses en España. Por eso en 1945 escribió que la reconstrucción gradual del Estado supone una justicia independiente. Para Alcalá Zamora eso implica el cese de jueces y magistrados que, en tribunales especiales, populares, o en la dictadura o esclavizados por esta, estén ligados a los horrores y a atropellos contra la libertad y derechos de los ciudadanos. Debe ser inútil la alegación de haberse plegado a esa serie de

209 Ibídem 384-386 y 429-477. Estas últimas palabras las recogió Guillermo Cabanellas, en la evocación de los últimos meses de la vida de Alcalá Zamora y de su sepelio. Lo hizo en Historia y Vida 95 (febrero 1976), se reproduce, Ibídem 537-551.

210 Alcalá Zamora, N. 1979. "Lemas de "La Voz Española”. Su ambiente y horizonte en el primer decenio, Buenos Aires, 15 julio 1945, 667.

${ }^{211}$ Alcalá Zamora, N. 1976. 468. 
prevaricaciones, por miedo, por terror, por coacción. No se les puede perdonar porque han preferido matar a morir.

Incluso, si se creyera su compromiso de proceder en adelante con justicia, les faltaría el prestigio externo y tendrían el recelo de los ciudadanos. No cabe más que buscarles compensación en otras carreras o mediante jubilaciones.

Para Alcalá Zamora la primera expresión de la concordia nacional es el repudio de todas las deudas contraídas por cada uno de los bandos para sostener y prolongar la guerra. En ningún caso debe pagarse, porque, desde el lado del Frente Popular ha salido más dinero y porque sería una inmoralidad que, para sostenerse la dictadura falangista, se entregara dinero a las democracias.

Estas, con una conducta así y gracias a la dictadura, legitimarían, en su provecho, su intervención en la Guerra Civil. En cuanto a las relaciones con las dos grandes potencias que intervinieron, la URSS no era ya su revolución, sino un Estado, cuyos fines políticos son los de una gran potencia. Alemania había dejado de existir como estado independiente tras su derrota. ${ }^{212}$

Recordó esa experiencia del primer bienio, que asemejó la política española con la de Lázaro Cárdenas en México. De ese error se aprovechó un sector de la sociedad española para hacer una ridícula versión de la respuesta dada por los católicos mexicanos, la Defensa Armada, con menor heroísmo pero con tanta o más barbarie. Alcalá Zamora citó a la Iglesia y a la Masonería. En esas dos referencias había algunas claves del conflicto y de su solución.

En países avanzados, la cruz no ha desparecido de sus emblemas nacionales. “¿Por qué el fanatismo rojo se opone a que la juventud mire hacia un crucifijo, símbolo de paz y de amor y que, además suele y debe ser obra de arte? A su vez, los fieles, los creyentes, no deben exhibir sus emblemas religiosos en lugares expuestos a profanaciones. Es evidente la misión social del clero. Por eso el Estado debe subvencionar a su formación, que será obra exclusiva de la Iglesia.

Alcalá Zamora cree que, en el advenimiento de la República, la masonería no tuvo papel decisivo. Supo beneficiarse de él. Intervino en la Constitución y en las leyes, facilitó disidencias y alianzas políticas, siempre en una dirección sectaria. Un indicador de que actúa así, es su exigencia de que el estado interviniera en las Asociaciones, pero dejando fuera a la masonería. La jerarquía interna crea subordinaciones en la vida de fuera de la masonería, imponiendo "primacías" y "compromisos" que se sobreponen a los deberes y preceptos que rigen la función pública.

Para la masonería, la misma norma que para la Iglesia: ni sumisión ni hostigamiento, sino prestigio e independencia del Estado.

\section{FRENTE A INJUSTICIA, PACIFICACIÓN Y CONVIVENCIA}

Pidió en marzo de 1937 que se trabajara en la pacificación nacional. Se perdieron los años de la Dictadura, "un régimen de injusticia y desvarío". Esos años se cumularon a los de la Guerra Civil. Los

${ }^{212}$ Alcalá Zamora, N. 2000. "Régimen político de convivencia en España, 1945, 147-148 y 1945. Buenos Aires, Editorial Claridad. 67-233. 
vencedores no se propusieron cerrar ese ciclo de enfrentamiento. Por eso, cuando desapareciera "el falangismo", la situación será aun peor que en abril de $1939 .{ }^{213}$

La República tiene que basarse en la convivencia nacional, en la pacificación de los espíritus. Se necesita para eso mantener el orden. Cada solución puede ser todo lo avanzada y audaz que se quiera, buscando el mayor progreso en la libertad y en la justicia social. Debe hacerse con mesura. Eso implica la renuncia y condena de la violencia, sea privada o de partido, y a la anarquía como medio de oprimir la acción del Gobierno. Este jamás debe ceder, bajo el pretexto de que debe plagarse a la "presión de la calle”. Ese desorden anuncia la catástrofe. Así pasó. ${ }^{214}$

Alcalá Zamora reflexionará sobre el problema del orden público, como problema político, como un asunto de modelo de Estado, en términos jurídicos y éticos.

Se debilita la defensa de los derechos y libertades individuales cuando los poderes públicos son débiles, claudican son cómplices, o, paradójicamente, cuando la autoridad solo puede firmar "órdenes de desorden".

Se negó en 1933 el Gobierno de Azaña a honrar a Bernardo López, autor de la Oda al Dos de Mayo. ${ }^{215}$ Lo recordó Alcalá Zamora en su discurso radiado el 2 de mayo de 1945, en Buenos Aires. Tres años más tarde, en 1936, esa izquierda llamó a ese pueblo de Madrid, en "aquel Madrid horrendo y triste de los horrores de la Guerra Civil". Fue necesario "que los espectáculos terribles del amanecer del 2 al 3 de mayo no fueran solo el recuerdo de Murat, sino que fuera el espectáculo macabro, doloroso, inicuo, de la lucha a muerte entre los españoles". 216

Cuando la violencia se ha deslizado hacia la extrema izquierda, cuando esta no acepta más que métodos de violencia y soluciones apresuradas, pero también cuando la reacción resiste pertinazmente e impide o ralentiza la justicia social, en cada uno de esos casos, las democracias van hacia el abismo. La democracia retrocedía ya en Europa. ${ }^{217}$

Habiendo sido la Constitución violada por el Frente Popular y por el Gobierno de Largo Caballero, se planteaba con mayor drama y urgencia su reforma. Se había llegado a una "ilegitimidad total". Con terquedad numantina se quiso irreformable, como se pretendía con el artículo 125. Los

${ }^{213}$ Alcalá Zamora, N. 2000. "Régimen político de convivencia en España, 1945, 159-164 y 138.

214 Alcalá Zamora, N. 2000. "Régimen político de convivencia en España, 1945, Obra Completa ... 129

215 Se refiere a los versos:

"Oigo, patria, tu aflicción

y escucho el triste concierto

que forman, tocando a muerto,

la campana y el cañón...”

216 Alcalá Zamora, N. 2000. "Fiesta Nacional del 2 de mayo. Sus vicisitudes y significación”, Buenos Aires, 2 mayo 1945, y 1979. 655.

217 Alcalá Zamora, N. 2000. "La tendencia antidemocrática", L’Ére Nouvelle, 26 abril 1938, "Confesiones de un demócrata", 112-114. Volvió sobre este asunto del eclipse de la democracia, "Salvación de la Nación y reforma del Estado, Ibídem 8 abril 1930, 174-176

Hispania Sacra, LXIV, Extra I, enero-junio 2012, 69-148, e-ISSN: 1988-4265, doi: 10.3989/hs.2012.027 
errores acumulados en ella, comprobados en los "tres años de experiencia constitucional", ${ }^{218}$ llevaron a la Guerra Civil. Encastillarse en esa oposición a la reforma será una obcecación execrable. ${ }^{219}$

Alcalá Zamora postuló la modificación del artículo 125, que, por su "rigidez extrema y absurda", hacía inmodificable la Constitución. Uno de los seguros contra la reforma era el interés de los diputados por seguir siéndolo, pues su aprobación suponía que el Congreso quedaba "automáticamente disuelto". 220

Derechas e izquierdas sociales superan a las derechas políticas en "incomprensión suicida", cerrilismo y fanatismo, que llevan a las guerras civiles. El drama de España, su mal incurable, reside "en el fanatismo brutal, y los egoísmos, suicidas por intransigentes". Es especialmente grave en las clases que se consideran cultas, pretender ser directoras, pero sin entender sus responsabilidades. Se llaman conservadoras, pero se comportan como demagógicas. No fueron capaces de prever lo que era necesario hacer a la caída de la Dictadura. No quisieron trabajar por una "república de orden y no de caos". No apoyaron "con sus sobradas fuerzas", soluciones que habrían salvado lo que había de justo y viable en sus intereses.

Se retiraron de las Cortes en el debate constitucional. Las derechas sociales organizaron el golpe del 10 de agosto de 1932.

En las elecciones de 1933 cometieron varios y graves errores: no declararse republicanas, para poder gobernar legítimamente, haber patrocinado una reacción que recordaba los tiempos de Isabel II, oponerse a un Concordato con la Santa Sede, practicar una demagogia blanca, cometiendo excesos y abusos, incluido el de la omnipotencia parlamentaria, en unas Cortes, controladas por ellas.

Hicieron una contra-reforma agraria, agravaron las condiciones de vida de los arrendatarios, que les negaron su voto en febrero de 1936. Patrocinaron una política triguera, atenta a los intereses de unos pocos. Su amnistía parecía burlar la justicia. Su victoria contra la Generalidad en 1934 se frustró en Barcelona.

Apoyaron al Partido Radical, pese a su ineficaz e inmoral administración, no colaborando con el Presidente de la República en la rectificación, porque la deriva reaccionaria de los radicales parecía favorecerles

Se opusieron a una reforma constitucional transaccional, creyendo que podrían hacerla a su medida en 1937. Dentro de esta resistencia, estaba el mantenimiento de la ley electoral. El culmen fue la crisis del 9 diciembre de 1935, que hizo caer al Gobierno de Joaquín Chapapietra, al que sucedió el 14 de diciembre el efímero de Portela Valladares, con aquel en Hacienda, pero que dejó de serlo en la crisis del día 30.

La República española puede servir de experiencia a otras democracias. Una de las causas de su ruina fue la opción por la Cámara única y todopoderosa. Fue claramente inferior a sus funciones, casi incapaz para legislar. Paradójicamente fue la ausencia de freno lo que dio ese resultado. Se podía provocar enfrentamientos, herir sentimientos e intereses. Incluso se buscó eso sin medir sus efectos.

${ }^{218}$ Con este título, se publicó el trabajo que hizo en 1935 para preparar su reforma, editado en 2002. 247-301.

${ }^{219}$ Alcalá Zamora, N. 2000 y 1945. "Régimen político de convivencia en España, 1945, 119 y 120-121.

${ }^{220}$ Alcalá Zamora, N. 2000. "Régimen político de convivencia en España, 1945, 133. 
Los perjudicados tenían que elegir una Cámara "totalmente opuesta". En cuatro años, la Gaceta estaba sobrecargada de textos, sin eficacia, porque se destruían mutuamente. Muchas de las instituciones siguieron funcionando con las normas de la monarquía y hasta de la dictadura.

Esos textos eran irreflexivos. Un ejemplo: el Tribunal de Garantías Constitucionales. Se hizo con retraso la Ley que regulara su funcionamiento. Alcalá Zamora halló en ella "las monstruosidades inconstitucionales más inconcebibles". La Ley de Confesiones y Congregaciones religiosas es un segundo ejemplo. El objetivo era "alcanzar la cumbre del laicismo" en breve plazo. El medio, la escuela pública. El plazo, dos meses para la enseñanza secundaria y cinco, para la primaria. Esa falta de realismo hizo que las cosas siguieran igual.

"Quitándoles a las leyes toda estabilidad, así como el sentido de la realidad y la primacía del interés general, la Cámara todopoderosa no hizo más que mostrarse incapaz en su función legislativa. Esto iba a demostrar que esto era así para sus otras prerrogativas parlamentarias.

La Cámara única representa "el conjunto de los peligros, los excesos y los vicios de una convención, sin la grandeza de ésta". Desprecia a la oposición y llega a suprimirla. Las minorías se perciben como "el obstáculo odioso que se alza contra el sueño del poder absoluto".

El resultado fue que las Cortes constituyentes, Cortes ordinarias desde diciembre de 1931, fueron desaprobadas dos años más tardes. Las elegidas en diciembre de 1933, fueron derrotadas en febrero de 1936. Las elegidas ese año convocaron compromisarios, en lo que podía llamarse "estado de guerra", para elegir nuevo presidente de la República, tras destituir al anterior el 7 de abril.

Esta Cámara única acabó con las prerrogativas de los diputados, especialmente con su inmunidad. Limitando las posibilidades de disolución, prerrogativa del presidente, cuando las Cortes estaban alejadas de la opinión y sin su apoyo, se corría el riesgo de recurrir a la violencia. Eso explica los sucesos de agosto de 1932 y los de julio de 1936. Alcalá Zamora no menciona la revolución de octubre de 1934, porque debe considerar que las mayorías, a menos de un año de su elección, contaban aún con el apoyo de la sociedad.

A esos se suma la falta de consideración a la dignidad de los otros parlamentarios. Ante la amenaza de muerte a Calvo Sotelo, el Presidente de las Cortes no calló. No hizo el menor gesto de protesta. $^{221}$

"La pobre Constitución española era la más defectuosa, la menos viable, entre todas las que existen en el mundo, y entre las que España ha padecido. Conducía a la guerra civil y, herida mortalmente antes incluso de que esta estallara, no pudo resistir. Condenada a desaparecer por la exigencia vital de la salud de España, si esa Constitución hubiera de ser restablecida, para ser abrogada incesantemente, tendría por necesidad que resucitar para morir, porque ya está muerta". 222

221 Alcalá Zamora, N. 2000. "La inferioridad legislativa y la Cámara todopoderosa", y "El suicidio parlamentario de la Cámara única", L'Ére Nouvelle, 18 y 25 septiembre 1937, "Confesiones de un demócrata", 63-68.

${ }^{222}$ Alcalá Zamora, N. 2000. "Facilidades negativas para la paz en España", L’Ére Nouvelle, 21 octubre 1937, "Confesiones de un demócrata", 76. 
El error decisivo de la derecha fue su conducta en las nuevas Cortes. Alcalá Zamora la denuncia por demagógica, violenta, destemplada, indecorosa. Olvidaban que por esa vía, la izquierda les llevaba ventaja y sus políticos se permitieron "el lujo de aparecer más prudentes y educados". Hicieron campaña en 1936 contra Alcalá Zamora y contra la República. De ese modo se enajenaron votos. En cambio muchos, además de los que abandonaron a la derecha, salieron de su abstención y votaron al Frente Popular. Los ganadores de los comicios se deslizaron hacia la dictadura demagógica. Esa fue su bandera esos meses. Esa demencia arruinó a España.

Fiel a su planteamiento, creyó que el Partido Progresista hizo todo lo que pudo, dada su debilidad parlamentaria y la actitud de la derecha y de la izquierda. Aquella debió asistirlo. No lo hizo.

En el balance final, la República salvó la unidad nacional frente al catalanismo, las vidas de la familia real y de quienes fueron ministros de la Dictadura, el orden público, pese a las jornadas de mayo de 1931 y a los sucesos de 1932 y a la agitación social en Andalucía entre 1931-1933. Fortaleció el Ejército. Respetó a la Iglesia, con la libertad de creencias y de culto, y mantuvo las órdenes religiosas, salvo la Compañía de Jesús. Salvó la propiedad privada, la "economía clásica" y el crédito público. Dio dignidad política a España, al "redimirla de pronunciamientos y golpes de Estado". Llegó en paz, legalmente, sin violencia. "Hubo una República con serena y noble alegría, que han trocado en los horrores de la guerra civil

Como errores, la ausencia del Senado, un sistema electoral injusto, y no haber logrado un Concordato. No se pudo evitar el atentado jurídico contra los jesuitas. La reforma agraria dañó el crédito para la agricultura. Cayeron las inversiones en ella, sin que los campesinos sin tierras mejoraran mucho sus condiciones de vida. No se logró una reforma serena para la enseñanza religiosa.

No podían salvarse las diversas jurisdicciones, las restricciones a la libertad religiosa, la unión Iglesia-Estado, los privilegios de la aristocracia... ${ }^{223}$

Pobre y defectuosa, la Constitución había sido destruida por la guerra desde su prólogo y su inicio. Ahora se quería dejar fuera su título preliminar y la unidad nacional. El grupo de Bratislava creía que una serie de plebiscitos -en plural- deberían decidir la suerte de España como nación. Eso sería la "westfalización" de España. Ella seguirá viviendo y será "centralista, unitaria, autónoma o federativa, según su sola soberanía, pero no por plebiscitos internacionalmente dirigidos, impuestos o amañados".

En agosto de 1938 se habló de una anexión de Cataluña a Francia, un "Anchluss" franco-catalán. La historia estaba en contra. Era testigo del error de Cataluña en la guerra de sucesión. Felipe V mantuvo los fueros vascos y navarros. Hay una explicación de eso.

“El extremismo catalán se caracteriza por el apartamiento máximo de las realidades, de las conveniencias del presente; y no se le puede pedir que perciba y respete mejor los datos de su constante tradición histórica. Ha cometido muchas locuras, desde 1934 al menos, contra el interés general de la República. Española y contra la autonomía de Cataluña, creyendo y queriendo servirlas y defenderlas. Ha sido ella la obra de esa paradoja psicológica agravada al jugar en manos de gobiernos regionales inverosímiles".

${ }^{223}$ Alcalá Zamora, N. 2002 y 1945. "Régimen político de convivencia en España. 92-95. Sobre la relación Cortes y Senado en "Tres años de experiencia constitucional”, 267-274.

Hispania Sacra, LXIV, Extra I, enero-junio 2012, 69-148, e-ISSN: 1988-4265, doi: 10.3989/hs.2012.027 
Otro ejemplo de esta huída de la realidad fue "la extraña y aun misteriosa alianza a que, al fin, llegó el Partido nacionalista vasco, casi y sin casi confesional, de orden y aun derechista, con la anarquía sindicalista y el comunismo revolucionario" en septiembre de 1936. Tenían una justa reivindicación desatendida la de restablecer la elección para las diputaciones forales. Ahora llegaban a todo a cambio de un estatuto federal. Los nacionalistas vascos cumplieron su parte. Se asociaron a "toda violencia del Frente Popular".

Cuando estalló la guerra ni vacilaron ni quizás les era fácil retroceder. Fueron unidos a una guerra civil, no lo habrían hecho para una guerra exterior. En las trincheras, codo con codo, "combatían juntos rezos y blasfemias".

Los sublevados, derogaron el estatuto catalán. Los otros aprobaron el vasco. No importaba el "territorio", pero sí sumar aliados. La evolución de la guerra convirtió todo eso en "singulares ficciones" desoladoras, en las que se malgastaron los recursos de los españoles.

"El federalismo español ha sido dañado, con torpeza y estrago enormes, por los que hubieran debido procurar salvarlo". 224

\section{LA PAZ, CUANTO ANTES}

Nadie podría creer en la conveniencia de que la guerra civil española se convirtiera en

un conflicto europeo. Esperaba en junio de 1938 Alcalá Zamora que la Asamblea de la Sociedad de Naciones refrendara esa posición. Los gobernantes que estuvieran en contra deberían recordar la historia de España y la actitud de los españoles contraria a actuar sometidos.

"La paz, lo antes posible, es una necesidad para todos los españoles, desde el punto de vista nacional; para todos los Estados, en el orden de las repercusiones internacionales; para la democracia en todas sus significaciones y encarnaciones, ya demasiado comprometidas en provecho de la reacción fascista, precisamente por el efecto de la prolongación de la guerra civil".

El camino hacia la paz debe recorrerse con "gran velocidad".

En los cálculos sobre el final de la guerra civil había dos expectativas: prolongarla para enlazar con una guerra mundial y resistir hasta que se derrumbe el enemigo, con el levantamiento de las "quintas columnas". Esta idea se mostró inútil. Las "quintas columnas" no han servido, salvo para precipitar, en algunas horas, la entrada de los vencedores en las ciudades, cuya caída era ya segura.

El segundo factor sería el hundirse la retaguardia, socavada por el cansancio, por los sufrimientos. Eso podría crear un clima propicio para mejorar las condiciones de paz. Es una quimera creer que la población, viviendo en la miseria tiene energía para levantarse.

Visto todo esto, prolongar la guerra no tiene más que un resultado: el agotamiento de España. Eso a nadie conviene ni siquiera es racional desde el egoísmo por el bien de todos. ${ }^{225}$

224 Alcalá Zamora, N. 2003. "La suerte probable del federalismo español”, La Nación, 13 abril 1939,“Artículos publicados en el diario “La Nación” (Buenos Aires, 1936-1939), 213-216

Hispania Sacra, LXIV, Extra I, enero-junio 2012, 69-148, e-ISSN: 1988-4265, doi: 10.3989/hs.2012.027 
Entre las causas de la guerra civil se hallan el fanatismo ideológico y la "aplicación abominable del materialismo histórico".

Acudiendo a ejemplos históricos afirma Alcalá Zamora que "no basta, en absoluto, en España, para dominarla o para llevarla por la vía de aventuras internacionales el tener un Gobierno dócilmente impuesto, o fanáticamente amigo, e incluso llegado el caso, podríamos prescindir de él”. La razón es que el pueblo español no se somete sin replicar a las decisiones que se toman en el Ministerio de Estado. ${ }^{226}$

Frente a ese horizonte de esperarlo todo de una guerra "extendida", las metas de la política exterior de España han de ser defender la independencia nacional; no mezclarse en "el avispero europeo"; conservar su neutralidad con ocasión de guerras nacidas de motivos que no afecten directamente a España; y mantener el prestigio y el "rango de una gran potencia de orden moral para ejercer su misión conciliadora entre los demás pueblos".

La neutralidad española es la conclusión de una renuncia hecha en provecho de los grandes intereses de España. Nadie puede pedirle que sea beligerante con Europa, estando "sometida" como si fuera ya solo "un Estado vasallo".

Le cuadra el papel de refugio de la solidaridad europea, de puente de civilización occidental entre Europa y América. Ese papel es necesario en la crisis mundial. "Solo España puede interpretarlo bien y por el bien de todos". 227

\section{CONCLUSIONES: DE LOS DISCURSOS A LA VIDA}

Los Discursos de Alcalá Zamora son un "iceberg" cuando se considera la obra de Alcalá Zamora como estadista. En tiempos de "consenso", de apuesta por acabar con todo lo que llevó a una guerra sangrienta, hay que recuperar su figura, sacarla del silencio y de los ataques de quienes estuvieron a su lado, con él o contra él, en aquellos años. Casi todos, salvo el socialista Juan Simeón Vidarte, fueron duros al enjuiciar a quien fue el primer Presidente de la República. Los historiadores deben sentirse libres de la manipulación operada durante el franquismo y "del apasionamiento y ligereza de juicios de tiempos demasiado cercanos a los hechos".

Recuerda Tuñón de Lara la postura de Alcalá Zamora en relación a la amnistía de los militares que participaron en los sucesos del 10 de agosto de 1932. Se opuso a los nombramientos de Franco, de Goded, de Mola, de Varela... La izquierda no supo valorar esa defensa de la Constitución y de la República.

Tuñón señala que ha llegado el momento de pensar si la destitución de las Cortes el 7 de abril, fue acertada: se hizo por medio de "una argucia leguleyesca", poco justificable. La izquierda no supo

225 Alcalá Zamora, N. 2000. "El camino de la paz" y "La otra esperanza", L’Ére Nouvelle, 10 junio y 7 julio 1938, "Confesiones de un demócrata", 121-123 y 126-127.

${ }^{226}$ Alcalá Zamora, N. 2000. "El dueño de la política exterior española", L'Ére Nouvelle, 12 diciembre 1937, "Confesiones de un demócrata", 85.

227 Alcalá Zamora, N. 2000. "La orientación exterior de España”, L'Ére Nouvelle, 7 enero 1938, "Confesiones de un demócrata", 91-93. 
valorar entonces la amenaza fascista. Aquel acto ¿favoreció o perjudicó a la democracia republicana? No responde Tuñón, pero el hacer la pregunta en 1978 era ya una toma de posición. ${ }^{228}$

Alcalá Zamora era una persona buena, excepcional, originalísimo, honrado y de una conducta limpia en todos los órdenes de la vida... Su figura, pese a sus errores, que los tuvo, sale nimbada de una aureola de bondad, de patriotismo, de rectitud, de honradez acrisolada y de ferviente deseo de acierto, virtudes congénitas en que plasmó su respetable personalidad". ${ }^{229}$

Desde la melancolía y casi desde la depresión de la hora presente, 1998, escribió Santos Martínez Saura que los hombres que trajeron la República "quisieron evitar toda tragedia" y que vivieran en paz todos los españoles. Se perdió la República. Vino luego una grave crisis moral. "Acciones que siempre se consideraron viles y miserables, se aceptaron después...[pero] antes de aquello España no era así”.

La República, breve, fue casi un "relámpago de civilización, de modernismo, de democracia". Pereció por la intervención extranjera de italianos, portugueses y alemanes y marroquíes. Un factor decisivo fue el ambiente fascista. Es el lamento de quien cedió de su poción inicial radical-socialista para llegar a la fusión con Acción Republicana y formar luego Izquierda Republicana. ${ }^{230}$

Deseaba Alcalá Zamora que las puertas de la República se abrieran a todos los partidos de buena fe para que entraran en lo que llamaba "vuestra propia patria". La lucha política lícita es la que se hace dentro del Derecho, en las elecciones, en la propaganda, en el Parlamento, buscando el asentimiento del país y respetando a todos los poderes.

Tras su muerte en Buenos Aires el 18 de febrero de 1949, Leandro Pita Romero leyó un escritotestamento. En él se aconsejaba a todos, pero "especialmente a los partidarios de la República", que, para que esta tuviera futuro, "afirmen y practiquen resueltamente: en las ideas, la paz y la libertad religiosa, sin fanatismos ni persecuciones sectarias". ${ }^{231}$

La vida constitucional de la República puso de manifiesto los defectos de la Constitución, que tanto y durante todo el tiempo preocuparon su primer Presidente. Fue anotando los artículos que deberían reformarse.

La izquierda quiso que la Constitución fuera irreformable. La derecha, consolidada su alianza con los radicales, dejó a este las ventajas de usarla en el poder. La CEDA y la otra derecha hostil a la República pensaban tener mayoría suficiente en 1937. Por eso quiso retrasarla hasta esa fecha. A la vista de esa actitud, decidió Alcalá Zamora presentar su propuesta al Gobierno. ${ }^{232}$

228 “ Triste sino de algunos hombres como Alcalá Zamora...blanco de los denuestos y hasta de las chanzas de quienes confundían a un liberal, a un demócrata moderado que era Jefe del estado, con los equipos de la derecha oligárquica y antidemocrática”.Manuel Tuñón de Lara, "Prólogo a Alcalá Zamora, N. 1979. 31-34.

${ }^{229}$ Maura, M. 1995. Así cayó Alfonso XIII, Barcelona, Ariel 212-216.

${ }^{230}$ Santos Martínez Saura, 1999. 23, 35 y 222.

${ }^{231}$ Gil PecharromáN. J. 2005. 307 y 396

232 Alcalá Zamora, N. 2002. "Los defectos de la Constitución de 1931 y Tres años de experiencia constitucional", La reforma... se editó tras la crisis del 7 de abril. Su propuesta de reforma, del 8 septiembre 1935, Ibídem. 50-54 
Desde su formación jurídica, desde su experiencia política y desde su decisión de facilitar la convivencia entre los partidos, encaró el problema de la amnistía. Las amnistías, prodigadas por las Cortes, no han servido para pacificar. ${ }^{233}$

Una de las reformas que propuso fue la creación del Senado y la revisión de los artículos que regulan la Presidencia de la República. Se trataba de evitar los bandazos legislativos, cada vez que se forma una nueva mayoría. Esta es fácil de crear, porque la transacción entre sus integrantes es fácil, con la ayuda que proporciona el tener el poder. A cada uno de los que apoyan las nuevas mayorías, basta con darles lo que piden.

La mayoría, con ese reparto de beneficios, tiende a ser duradera y aspira a que las Cortes duren también. En una Cámara única la mayoría gobierna sin oposición. Dentro de esa coalición suele prevalecer el más extremista, que explota la necesidad de su concurso. Se abre un foso entre mayoría y oposición. Aquella se encastilla en sus intereses y en sus pasiones. No busca convivir, sino dominar.

Cuando se ha padecido esa situación, se busca la revancha. Unos y otros desean "la perpetuidad en el mando". Esto explica que las sesiones en las primeras Cortes nunca se interrumpieron y la previsión de periodos de sesiones superiores a los diez meses.

Históricamente la Cámara única ha manifestado sus tendencias a actuar en "convención", a ir al poder absoluto. Pasó con las Cortes Generales y Constituyentes de Cádiz. El Jefe del Estado queda sin posibilidad actuar frente a ese poder sin límites. Ni siquiera el control de constitucionalidad es eficaz para corregir los abusos de la Cámara.

Para no correr el riesgo de la inestabilidad de las instituciones, el remedio es el Senado. Debe dar que pensar que la Cámara única no existe casi en ningún país. El Senado no es contradictorio con la República. Lo había en Francia y en México, por poner dos ejemplos. ${ }^{234}$

Cuando llegó al final de su accidentado viaje de 441 días, desde Marsella a Buenos Aires, tuvo que contar "angustias, escaseces, privaciones, inquietudes, injusticias, durezas, más desconsideradas aun que crueles, y todo eso es inevitablemente opaco". Acabó sus días viviendo sobriamente, con sencillez, como un retirado, creyente en Dios, fiel a la Iglesia. Leandro Pita Romero escribió el 19 de febrero de 1949, al día siguiente de su entierro: Alcalá Zamora fue un español, exiliado, de "vida austera, noble, ejemplar, pura, rectilínea, magnífica". ${ }^{235} \mathrm{Y}$ en su última voluntad, dejó escrito:

"A cuantos españoles atiendan mi parecer leal y, especialmente, a los partidarios de la República, les aconsejo que para restablecer y conservar tal régimen, único en definitiva posible, afirmen y prediquen resueltamente: en las ideas, la paz y la libertad religiosa, sin fanatismo ni persecuciones sectarias; en el sentimiento, patriotismo intenso, sin tibiezas ni excusas por los fervores compatibles con la fraternidad universal o de las afecciones del alma hacia las regiones

${ }^{233}$ Las amnistías sólo podrán ser acordadas por el Parlamento. No se concederán indultos generales. El Tribunal Supremo otorgará los individuales a propuesta del sentenciador, del físcal de la Junta de Prisiones o a petición de parte.

En los delitos de extrema gravedad, podrá indultar el Presidente de la República, previo informe del Tribunal Supremo y a propuesta del Gobierno responsable" (artículo 102).

234 Alcalá Zamora, N. 2002. "Los defectos de la Constitución de 1931 y Tres años de experiencia constitucional", Obra Completa.. 2002,107-121. La reforma... se editó tras la crisis del 7 de abril. Su propuesta de reforma, del 8 septiembre 1935, Ibídem. 50-54. Vid. Alcalá Galve, A. 2006. 347-357.

${ }^{235}$ Alcalá Zamora, N. 1976 473-477. 
de cada uno; y en la vida y en la conducta, austera sencillez y diáfana gestión. Y siempre que sienta el horror a las guerras civiles, causa de todos los males patrios, supremo castigo de los pueblos, solo merecido por encerrar la suma de todos los crímenes". 236

Escribió en Pau en 1937 sobre las bases políticas de la convivencia entre los españoles. Al publicar sus reflexiones en 1945, en Buenos Aires, ${ }^{237}$ puso esta dedicatoria anónima:

“A los españoles para quienes la convivencia no es odio, ni el saludo trágala, ni la República, anarquía, ni el orden, explotación del trabajo, ni la justicia social, guerra de clases, ni la separación de la Iglesia y del Estado, incendio de templos, ni la libertad de conciencia, asesinato del clero. Ni la fe católica, persecución inquisitorial. Ni el amor a la patria nuestra, plagio de exóticos nacionalismos, ni la relación humana, exterminio del adversario.

Pudiera escribir aquí vuestros nombres, que, por desventura del país, no sois los más, pero comprendo y respeto que hombres cuerdos y honrados guarden el secreto, mientras la tardía y confusa riada de locura delincuente no vuelva a su cauce normal, ya de por sí desmesurado, en ese enorme manicomio judicial, en que no se desenvuelve y sí se destruye, aprisionada y trágica, la vida de nuestra pobre España". 238

Alcalá Zamora fue condenado por el Tribunal, que aplicó la Ley de Responsabilidades Políticas. La sentencia fue firme el 21 de junio de 1941. Se publicó en el Boletín Oficial del Estado el 28 de abril de 1944. Recurrió su hija María Teresa el 3 de diciembre de 1953. Se rebajó la multa de cincuenta millones a tres. Se autorizó a pagarla en cuatro plazos de 687.500 ptas. anuales. Sólo se pagó uno por no tener capacidad económica la familia. En 1966 se indultó el resto de la deuda. De la de extrañamiento o de inhabilitación política por 15 años, no fue necesario. Alcalá Zamora murió en 1949.

Hace años, en Roma, el arzobispo Maximino Romero de Lema, hablando de Ángel Herrera Oria. Recordó que, tras las elecciones de 1933, aconsejó a José María Gil Robles: 1lévate bien con Alcalá Zamora. Añadió el arzobispo: pero no le hizo caso. ${ }^{239}$ Con sorna y tristeza, añadió “...porque, pudiendo hacer las cosas mal, ¿por qué hay que hacerlas bien?”. Alcalá Zamora juzgó esto en toda su seria gravedad. ${ }^{240}$

La edición de los escritos políticos de D. Niceto Alcalá Zamora, la de sus Memorias, los testimonios recogidos en el Archivo de Vidal i Barraquer...confirman esta conversación. Ángel

${ }^{236}$ Alcalá Zamora, N. Testamento político, escrito en Buenos Aires el 14 de octubre de 1942, en 1976, 11. El testamento fue leído por Leandro Pita Romero en la ceremonia de entierro de Alcalá Zamora el 19 febrero 1949, Ibídem 550.

237 "Si alguien pensara que el deber hacia España pesa sobre mí en más alto grado que sobre nadie, yo me adelanto a proclamarlo y a cumplirlo, confesando que es obligación, no mérito; pero sin vanidad de monopolio ni de preferencias jerárquicas. Ojalá que, en torno al problema de España, surja, con fácil superación, una literatura, que lo sea por la abundancia de ideas y la unidad del asunto, no por las pretensiones de estilo". Alcalá Zamora, N. 2000. "Régimen político de convivencia en España, 1945, 232.

238 Alcalá Zamora, N. "Régimen político de convivencia en España, 1945, Ibídem 67. Cita esta dedicatoria su hijo Alcalá Zamora Castillo en su introducción a 2002. "Los defectos de la Constitución de 1931 y Tres años de experiencia constitucional", XIV.

${ }^{239}$ García Escudero, J.M.: 2009. El pensamiento de Ángel Herrera Oria. Antología política y social. Madrid: Biblioteca de Autores Cristiano. 212.

${ }^{240}$ La Constitución dejó abierta la pugna entre la Presidencia de la República y las Cortes. Lo fue con mayor encono en los tiempos de la CEDA. Vid. 2002. "Tres años de experiencia constitucional": 268-269. 
Herrera fue el primer presidente de la Junta Nacional de la nueva Acción Católica. Su nombramiento era un respaldo a la línea seguida por El Debate desde que llegó la República: acatar el poder, trabajar por el bien común y hacer del propio un campo abierto, donde hallen residencia y casa quienes apuestan por la concordia y la justicia.

\section{BIBLIOGRAFÍA.}

Alcalá Galve, A. 2006 Alcalá Zamora y la agonía de la República, Sevilla, Fundación José Manuel Lara, segunda edición

Alcalá Zamora, N. 1977. Memorias (Segundo texto de mis Memorias), Barcelona, Editorial Planeta,

Alcalá Zamora. N. 1979. "Proyecto de Ley de Reforma de la Ley Municipal", 9 febrero 1906, Discursos, Madrid, Editorial Tecnos Alcalá Zamora. N. 1979. "Proyecto de Ley de Reforma de la Ley Municipal”, 9 febrero 1906, Discursos, Madrid, Editorial Tecnos.

Alcalá Zamora. N. 2000. "Régimen político de convivencia en España, 1945, Obra Completa, Coordinación de la edición José L. Casas Sánchez, y Francisco Durán Alcalá, Priego de Córdoba. Apareció en Buenos Aires, Editorial Claridad, 1945.

Alcalá Zamora. N. 2002 "Régimen político de convivencia en España, 1945, Obra Completa, Coordinación de la edición José L. Casas Sánchez, y Francisco Durán Alcalá, Priego de Córdoba

Alcalá Zamora, N. 2003. Obra Completa, Coordinación de la edición José L. Casas Sánchez, y Francisco Durán Alcalá, Priego de Córdoba.

Alcalá Zamora, N. 2011 Asalto a la República. Enero-abril 1936, Madrid: La Esfera de los Libros.

Azaña, Madrid 1932. Una política (1930-1931), Bilbao, Madrid, Barcelona, Espasa Calpe 1932

Azaña, M. 1934. En el poder y en la oposición (1932-1934), tomo segundo, Bilbao, Madrid, Barcelona, Espasa Calpe.

Azaña, M.1968. Memorias políticas y de guerra, tomo IV, México, Oasis,

Cabanellas. G. 1978. Cuatro generales. Preludio de la Guerra Civil, Barcelona, Editorial Planeta.

Gil Pecharromán, J. 2005. Niceto Alcalá-Zamora, un liberal en la encrucijada. Madrid. Ed. Síntesis.

González Cuevas, Pedro Carlos. 2003. Maeztu. Biografía de un nacionalista español, Madrid, Marcial Pons.

Martínez Saura, S. 1999. Memorias del Secretario de Azaña. Edición y Prologo de Isabelo Herreros Martín-Maestro. Nota preliminar de Paloma Zubieta López, Barcelona, Editorial plantean, Colección España Plural.

Maura, M. 1995. Así cayó Alfonso XIII, Barcelona, Ariel

Ratzinger, J. 1995. Introducción al cristianismo, Barcelona, Planeta-Agostini.

Rivas Cherif, C. de. 1981, Retrato de un desconocido. Vida de Manuel Azaña (2), Barcelona: Grijalbo: 311. El libro fue escrito entre 1941-1943, mientras el autor estaba en la cárcel. La primera edición en esta editorial es de 1979

Simeón Vidarte, J. 1976. Las Cortes Constituyentes de 1931-1933. Testimonio del Primer Secretario del Congreso de los Diputados, Barcelona, Buenos Aires, México D.F. Dimensiones Hispánicas. 
Soderini, E. 1932 Il Pontificato di Leone XIII, tomo I, Milano, A. Mondadori.

Ucelay Da Cal, E. 2003. El imperialismo catalán. Prat de la Riba, Cambó, D’Ors y la conquista moral de España, Barcelona, Edhasa

Verdoy, A. 1992. "La incautación del Seminario Pontificio de San Antonio de Padua de Comillas durante la Segunda República, 1932-1935". Miscelánea Comillas: Revista de teología y ciencias humanas: L/96-97: 259-290. Ejemplar dedicado al I Centenario de la Universidad Pontificia Comillas (1892-1992)

Verdoy, A. 1995. Los bienes de los jesuitas: disolución e incautación de la Compañía de Jesús durante la Segunda República, Madrid, Trotta. 